\title{
Carboniferous to Lower Permian stratigraphy of the southern Tamworth Belt, southern New England Orogen, Australia: boundary sequences of the Werrie and Rouchel blocks*
}

\section{J. ROBERTS ${ }^{1 \dagger}$, R. OFFLER ${ }^{2}$ AND M. FANNING ${ }^{3}$}

'School of Biological, Earth \& Environmental Sciences, University of New South Wales, Sydney, NSW 2052, Australia.

${ }^{2}$ Discipline of Earth Sciences, School of Environmental and Life Sciences, University of Newcastle, NSW 2308, Australia.

${ }^{3}$ Research School of Earth Sciences, Australian National University, ACT 0200, Australia.

Carboniferous to Lower Permian successions along the western border of the Tamworth Belt between Wallabadah and Muswellbrook were remapped to clarify the stratigraphy and establish a boundary between the Werrie and Rouchel blocks. The boundary, located at the Waverley Fault, separates Carboniferous sequences containing different formations and volcanic members. SHRIMP AS3 dating of volcanic members indicates that successions within the Rouchel and Gresford blocks were deposited, uplifted and eroded at different times. The lacustrine Woodton Formation in the Werrie block, previously considered Carboniferous, is earliest Permian (Asselian) from palaeobotanical and SHRIMP AS3 evidence. Stratigraphic and palaeoenvironmental differences between the Werrie and Rouchel blocks suggest that they were not directly juxtaposed during the greater part of the Carboniferous, supporting palaeomagnetic evidence that blocks within the Tamworth Belt are allochthonous. Superposition of the western extremity of the Waverley Fault by Lower Permian (Sakmarian) formations and intrusion of folded and faulted Devonian to Lower Permian successions by the Barrington Tops Granodiorite (ca 280 $\mathrm{Ma}$ ) indicate that the Werrie, Rouchel and Gresford blocks were subjected to tectonism before the Late Permian Hunter-Bowen Orogeny.

KEY WORDS: Carboniferous, New England Orogen, Permian, Rouchel block, SHRIMP, stratigraphy, Tamworth Belt, uranium-lead dating, Werrie block.

\section{INTRODUCTION}

The Carboniferous forearc basin of the Tamworth Belt, southern New England Orogen, contains successions that vary from largely marine in the Tournaisian, partially marine in the Visean and early Namurian, to wholly continental throughout the remainder of the period. Regression was caused by development of the felsic Currabubula Volcanic Arc (Scheibner \& Veevers 2000) along the western margin of the forearc basin in the earliest Carboniferous (Roberts \& Oversby 1974; Trapp et al. 2004) and its continuation until the latest Carboniferous (Claoué-Long \& Korsch 2003; R. Offler unpubl. data). Changes in stratigraphy along the length of the Tamworth Belt and the existence of north-south faults in the southern part of the belt (Roberts \& Engel 1987) have led to the recognition of a number of major blocks, the Rocky Creek, Werrie, Rouchel, Gresford, Myall and Hastings blocks (Roberts \& Geeve 1999) (Figure 1). These are mostly fault bounded, and each is characterised, at least in part, by a stratigraphy distinct from that of other blocks (Roberts \& Engel 1987; Roberts et al. 1995c). Palaeomagnetic studies suggest that these blocks are allochthonous (Schmidt et al. 1994; Geeve et al. 2002; McElhinny et al. 2003), although Klootwijk (2002, 2003) considers most to be autochthonous. This paper examines the stratigraphy of the region between Wallabadah and Muswellbrook to establish a firm boundary between the Werrie and Rouchel blocks, and to clarify the stratigraphy of the Wingen area (Manser 1968). The geology of the Werrie block is characterised by the classic stratigraphy of Carey (1937) as modified by Voisey and Williams (1964), consisting of the Carboniferous portion of the Goonoo Goonoo Formation (Crook

\footnotetext{
*Appendix 3 and Tables 2-23 [indicated by an asterisk (*) in the text and listed at the end of the paper] are Supplementary Papers; copies may be obtained from the Geological Society of Australia's website (www.gsa.org.au) or from the National Library of Australia's Pandora archive (http://nla.gov.au/nla.arc-25194).

${ }^{\dagger}$ Corresponding author: j.roberts@unsw.edu.au
} 
1961) and Namoi, Merlewood and Currabubula Formations. In contrast, Carboniferous formations in the Rouchel block (Roberts \& Oversby 1974; Roberts et al. 1991) include the Kingsfield, Dangarfield, Goonoo Goonoo, Waverley, Isismurra and Seaham Formations. Detailed mapping of ignimbrites indicates further differences between the blocks. SHRIMP AS3 dating of selected ignimbrites and marine intercalations containing brachiopods have provided accurate means of comparing successions within the adjoining blocks and their histories of uplift and erosion. The Woodton Formation (new name), previously identified as part of the Currabubula Formation (Davies 1988; Dawson 1988), is now known to be earliest Permian (Asselian) in age from palaeobotanical and SHRIMP AS3 dating.

The Wallabadah-Muswellbrook and adjacent areas dealt with in this paper are covered by the Quipolly 9035-3S, Emblem 9035-2-S, Quirindi 9034-4-N, Wallabadah 9034-1N, Warrah 9034-4-S, Temi 9034-1-S, Isis River 9134-4-S, Murrurundi 9034-2-N, Timor 9134-3-N, Parkville 9034-2-S, Waverley 9134-3-S, Scone 9033-1-N, Woolooma 9133-4-N, Aberdeen 9033-1-S, Rouchel Brook 9033-4-S, Muswellbrook 9033-2-N and Dawsons Hill 9133-3-N 1:25 000 topographic sheets. Detailed geological information on these sheets is stored on the New South Wales Mineral Resources computer database. Grid references are to the Australian Map Grid, AGD66 datum. SHRIMP dates based on the AS3 and/or FC1 standards are given to an error of $1 \sigma$. The timescale used in this paper follows the usage of Roberts et al. (2003) in that the Australian Upper Carboniferous is equivalent to the Namurian, Westphalian and Stephanian Stages of Western Europe. This usage differs from the international time-scale because the Mississippian and Pennsylvanian Subsystems cannot be recognised throughout Gondwanan continents.

\section{GEOLOGICAL SETTING}

During the Carboniferous Period, the southern New England Orogen consisted, from west to east, of a volcanic arc (Currabubula Volcanic Arc), forearc basin (Tamworth Belt), subduction - accretion complex (Tablelands Complex), and a zone interpreted in terms of convergent tectonics as a west-dipping subduction zone in which the palaeo-Pacific plate underthrust Gondwana. Cessation of arc-type volcanism in the Late Carboniferous was attributed to the intersection of an active mid-ocean ridge-transform-fault system with the subduction zone (Murray et al. 1987), an eastward migration of the subduction zone caused by slab breakoff (Caprarelli \& Leitch 2001) or rollback at ca $300 \mathrm{Ma}$ (Jenkins et al. 2002). Extension in the Early Permian was responsible for initiation of the Sydney and Gunnedah Basins and widespread basaltic to rhyolitic volcanism. Folding and major overthrusting associated with the Hunter and Mooki Thrusts took place throughout the Tamworth Belt in the Late Permian. Evidence of an earlier compressive deformation is provided by the existence of the Waverley Fault prior to the Early Permian Temi Formation and Werrie Basalt, and the intrusion of folded and faulted Devonian, Early Carboniferous and Early Permian formations by the
Early Permian (ca $280 \mathrm{Ma}$ ) Barrington Tops Granodiorite (Figure 1) (Bradshaw 1982; Cross 1983; Roberts et al. 1991; Kimbrough et al. 1993).

The present study covers the western margin of the Tamworth Belt between Wallabadah and Quirindi in the north, Muswellbrook in the south, and the Mooki and Hunter Thrusts in the west (Plate 1). The thrust margin is offset sinistrally by the Murrurundi Fault which cuts off the north-northwest-trending Mooki Thrust in the vicinity of Temi and the largely north-south-trending Hunter Thrust some $13 \mathrm{~km}$ towards the east-southeast near Blandford. South of Scone, there is a further eastward offset in the vicinity of the Hunter River northeast of Aberdeen, with the thrust margin located adjacent to Colonel and Bells Mountains. South of Bells Mountain, the Hunter Thrust makes an abrupt bend and extends eastwards across the northern margin of the Hunter Valley to Maitland. Structures in the southern part of the Werrie block include the Quipolly, Quirindi and Castle Mountain Domes, Back Creek Anticline and Temi Syncline. In the southernmost part of the Werrie block, between the Murrurundi and Waverley Faults, Carboniferous rocks form an eastern limb of the Sandy Creek Syncline (Manser 1968). Permian units in the Sandy Creek Syncline and an adjacent anticline are tightly folded. Trends of folds and faults in the Werrie

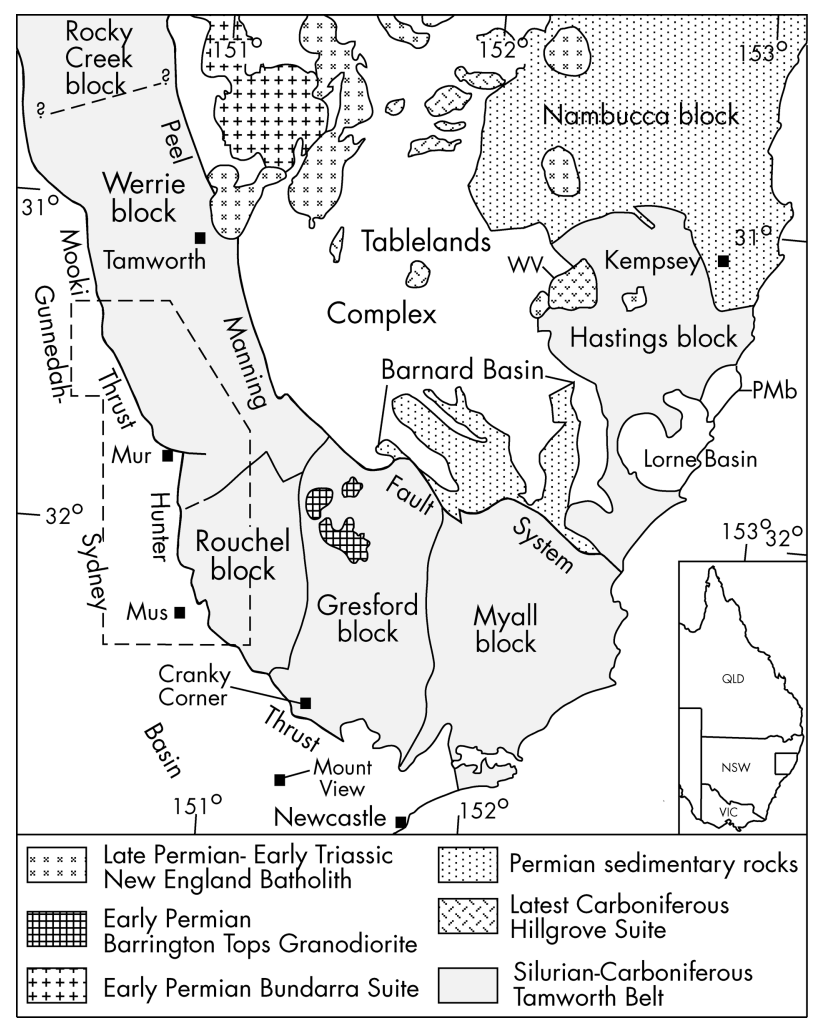

Figure 1 Regional map of the southern part of the southern New England Orogen showing the blocks characterised by different Carboniferous successions in the Tamworth Belt (grey tone), the Nambucca block and major features of the Tablelands Complex. WV, Triassic Werrikimbe Volcanics; $\mathrm{PMb}$, ?Silurian to Late Devonian Port Macquarie block; Mur, Murrurundi; Mus, Muswellbrook. The study area is outlined by the dashed box. The inset shows the location in eastern Australia. 
block are predominantly north-northwest to north - south but in the southwestern part are northeast. Structures in the Rouchel block have a greater diversity, trending predominantly northeast but also east - west, northwest, north-northwest and north-south. Faults are more common and the fold traces shorter when compared to those in the Werrie block. The northeast trend is anomalous in the frontal system of the Tamworth Belt and is interpreted as having been caused by an inferred basement buttress located northwest of the Waverley Fault (Collins 1991; R. A. Glen, R. Offler \& J. Roberts unpubl. data). The structure of the region and explanation for the block rotation will be dealt with in a separate paper.

\section{STRATIGRAPHY}

Carboniferous rocks in the Werrie block between the northern closure of the Werrie Syncline and the Castle Mountain Dome were mapped by Carey (1934, 1937). Carey's (1937) formations, as modified by Voisey and Williams (1964), have remained virtually unchanged since his original comprehensive study. Subsequent additions to the stratigraphy include the Kyndalyn Member of the Merlewood Formation (Moore \& Roberts 1976) and the Rosedale Member (Whetten 1965), Cana Creek Tuff Member and the Iventure, Taggarts Mountain and Piallaway Trig Ignimbrite Members (McPhie 1983) of the Currabubula Formation. Geological mapping by students from the University of New England (Lowe 1971; Warner 1972; Cherry 1987; Davies 1988; Dawson 1988) in the region between the Quipolly Dome and the Murrurundi Fault identified a new Carboniferous lacustrine unit between the Currabubula and Temi Formations. This unit, herein formally named the Woodton Formation, was regarded as a disconformable member at the top of the Currabubula Formation. It is now known to be earliest Permian in age from palaeobotanical and SHRIMP AS3 evidence. Rhyodacitic lava in the Back Creek Anticline (McPhie 1984) has been identified as the uppermost part of the Woodton Formation (Kelk 1986).

Prior to publication of a geological map of the Wingen region (Manser 1968), the only mapping undertaken in the Carboniferous succession south of the Liverpool Range was that of Osborne (1950). Manser's (1968) mapping extended from Parkville north to the southern margin of the Tamworth 1:250000 sheet (Offenberg 1971). New Carboniferous formations recognised by Manser (1968) extended across the region that we now recognise as containing the coeval, but distinctive, boundary successions of the Werrie and Rouchel blocks. Application of his new formations, some of which had reference sections in both the Werrie and Rouchel blocks (Manser 1967), led to confusion in the Carboniferous stratigraphy of the Wingen region. For example, the Waverley Formation was based on a type section extending west from Isis Hills in strata now recognised as Merlewood Formation (Plate 1), and one of the two reference sections for the Isismurra Formation taken southwest from Isismurra is in strata now mapped as Merlewood Formation.

Detailed descriptions of new and revised stratigraphic units are given in Appendix 1, measured stratigraphic sections are shown in Figures 2, 3, 5, 7-9, and time correlations between the blocks are illustrated in Figure 10. Details of SHRIMP dating are provided in Table 1, Appendices 2 and $3 *$ and Tables $2^{*}-21^{*}$. X-ray fluorescence (XRF) analyses and locality details of selected samples are given in Tables $23^{*}$ and $24^{*}$.

\section{Werrie block}

In this paper, Carboniferous formations identified in the Werrie Syncline can be traced to the Waverley Fault, except in areas covered by Cenozoic basalt (Plate 1).

\section{MERLEWOOD FORMATION}

The Merlewood Formation (Voisey \& Williams 1964; McKelvey \& McPhie 1985) crops out along the eastern limb of the Werrie Syncline, east of the Quipolly and Castle Mountain Domes and Back Creek Anticline (Plate 1) and extends southwards to the Waverley Fault. It conformably overlies the Lower Carboniferous part of the Goonoo Goonoo Formation and is overlain disconformably by the Namurian to Westphalian Currabubula Formation. The Merlewood Formation consists predominantly of pink, zeolitic, volcanolithic sandstone and conglomerate with minor siltstone, mudstone, carbonaceous shale, claystone, minor diamictite and ignimbrite. Multicoloured ash-rich siltstones containing glass shards and feldspar crystals are commonly associated with the ignimbrites. The major occurrence of diamictite at locality 466-2 (0302791E 6492110N Temi 1:25000 sheet) contains diverse, angular to rounded clasts, slumped beds and grades upwards into a pebble to boulder conglomerate.

\section{Members of the Merlewood Formation}

In contrast to the type area on the northwestern limb of the Werrie Syncline (Voisey \& Williams 1964), which contains up to four flows of andesite (J. Roberts unpubl. data), the Merlewood Formation in the WallabadahWaverley district is characterised by thin, normally unwelded, rhyolitic to rhyodacitic ignimbrites. The oldest volcanic unit, the Isismede Ignimbrite Member, is a red, partly reworked, unwelded ignimbrite. It crops out sporadically in four localities, one north of the Liverpool Range, $5 \mathrm{~km}$ southeast of Wallabadah, and three adjacent to the Isis River in the belt between the Murrurundi and Waverley Faults (Plate 1). Two of three SHRIMP AS3 analyses used to correlate these localities give ages of $c a$ $352 \mathrm{Ma}$ (sample 501-4, Figure 11c; sample 470-13, Figure 11a) whilst the third (sample 490-2, Figure 11b) is older, $c a$ $355 \mathrm{Ma}$, possibly because of high common $\mathrm{Pb}$ and relatively low U contents. The SHRIMP AS3 age is taken at $352 \mathrm{Ma}$. None of the younger ignimbrites in the Merlewood Formation is present in the succession cropping out between Wallabadah and the Liverpool Range.

The Burnewang Ignimbrite Member is known from a single outcrop south of the Liverpool Range at Rockley (Figure 2) but, farther south, is essentially continuous from west of Green Creek to an arcuate fault on Isis Hills; further outcrops are present to the south adjacent to the Waverley Fault (Plate 1). It varies from a single, dense, red ignimbrite to thin interbeds of ignimbrite, 


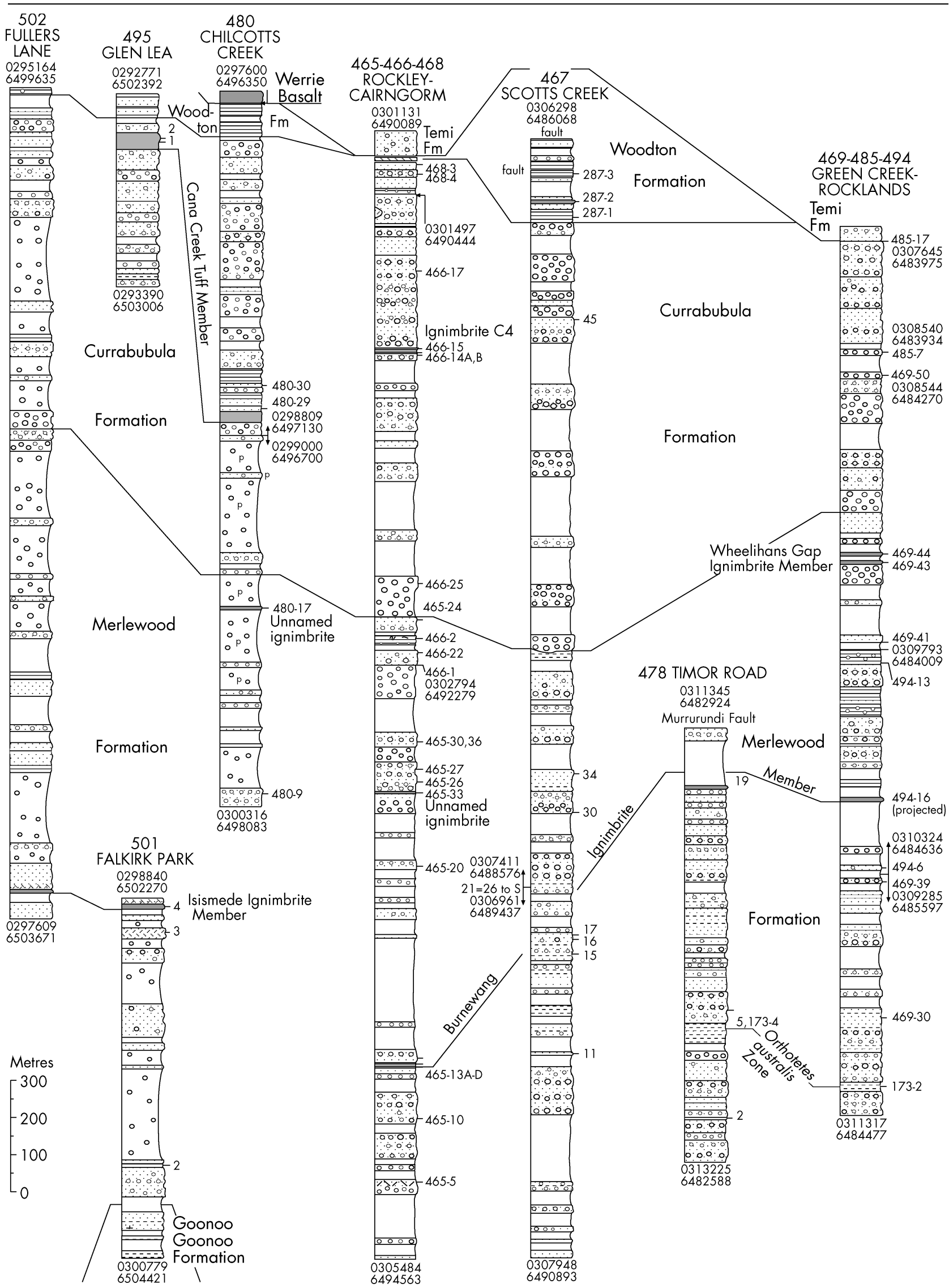

Figure 2 Measured stratigraphic sections from the region between Wallabadah and the Murrurundi Fault, southern Werrie block. These illustrate the succession from the Carboniferous Goonoo Goonoo, Merlewood and Currabubula Formations to the Permian (Asselian) Woodton Formation, and (Sakmarian) Temi Formation and Werrie Basalt. See Figure 3 for legend. 


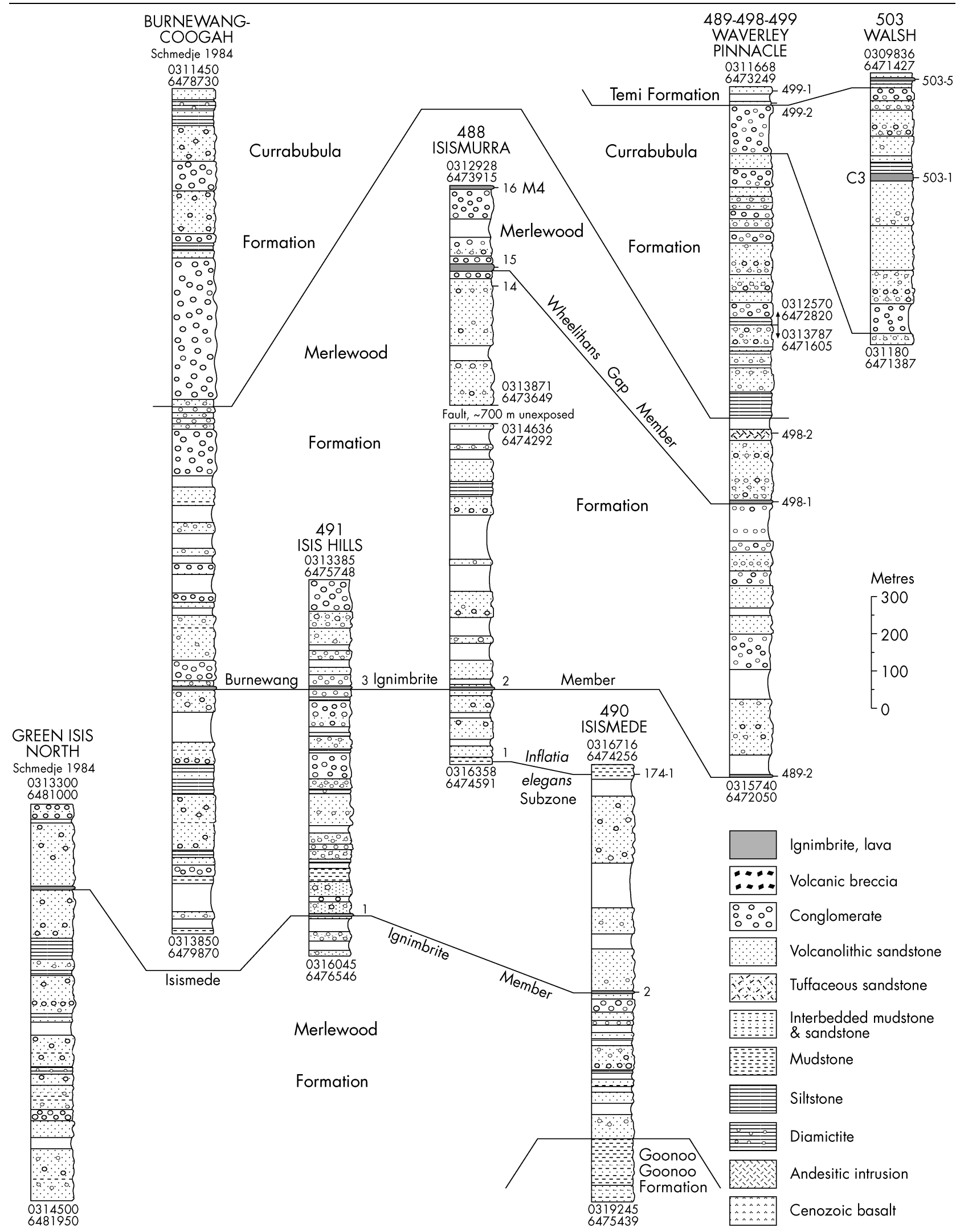

Figure 3 Measured stratigraphic sections between the Murrurundi and Waverley Faults, southernmost Werrie block. The succession extends from the Carboniferous Goonoo Goonoo, Merlewood and Currabubula Formations to the Permian (Sakmarian) Temi Formation. 


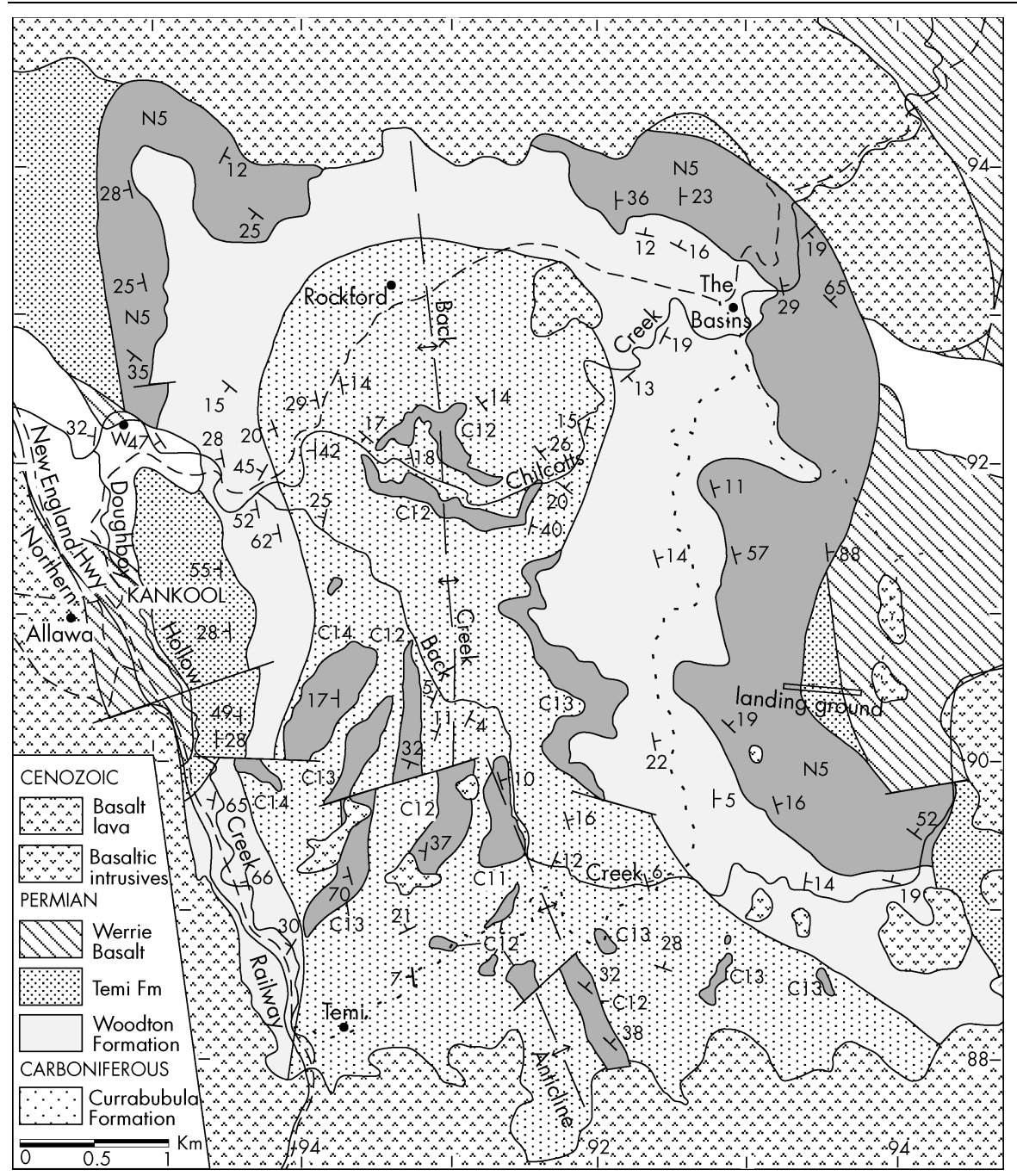

Figure 4 Geological map of the Back Creek Anticline (from Kelk 1986), north of the Liverpool Range, illustrating ignimbrites in the upper part of the Currabubula Formation and the Willawarrra Rhyodacite Member of the earliest Permian (Asselian) Woodton Formation. Volcanic members in the Currabubula Formation include C 11 Kankool Ignimbrite Member, C12 Chilcotts Creek Ignimbrite Member; C13 Rockford Ignimbrite Member and C14 Allawa Ignimbrite Member. N5 is the Willawarra Rhyodacite Member of the Woodton Formation. siltstone and volcanolithic sandstone; some exposures have been reworked (Appendix 1). Two of three SHRIMP AS3 dates taken from samples of the member are $c a$ $343 \mathrm{Ma}$ (sample 465-13A, Figure 11d; sample 472-1, Figure 11e), but a third (sample 488-2A, Figure 11f) is older, having an age of close to $349 \mathrm{Ma}$. The SHRIMP AS3 age is taken as $343 \mathrm{Ma}$ (Appendix 1), Brachiopods belonging to both the Early Visean Orthotes australis Zone and Inflatia elegans Subzone are present between 650 and $100 \mathrm{~m}$, respectively, beneath the Burnewang Ignimbrite Member (section 478, Figure 2; sections 488, 490, Figure 3).

Two younger ignimbrites are present at the top of the Merlewood Formation. The Wheelihans Gap Ignimbrite Member, a fine, grey, purple or beige ignimbrite, crops out west of Green Creek, where it is cut by the Murrurundi Fault. An easterly displaced remnant south of the fault extends for only $0.4 \mathrm{~km}$ before being removed by erosion at the disconformable base of the Currabubula Formation. The Wheelihans Gap Ignimbrite Member reappears in a block immediately north of the Waverley Fault, northeast of Waverley Pinnacle (Plate 1). The SHRIMP AS3 age of $327.4 \pm 3.7 \mathrm{Ma}$ (sample 469-43, Figure 12a) is virtually the same as that of unnamed ignimbrite M4 (328.1 \pm 2.9 Ma: sample

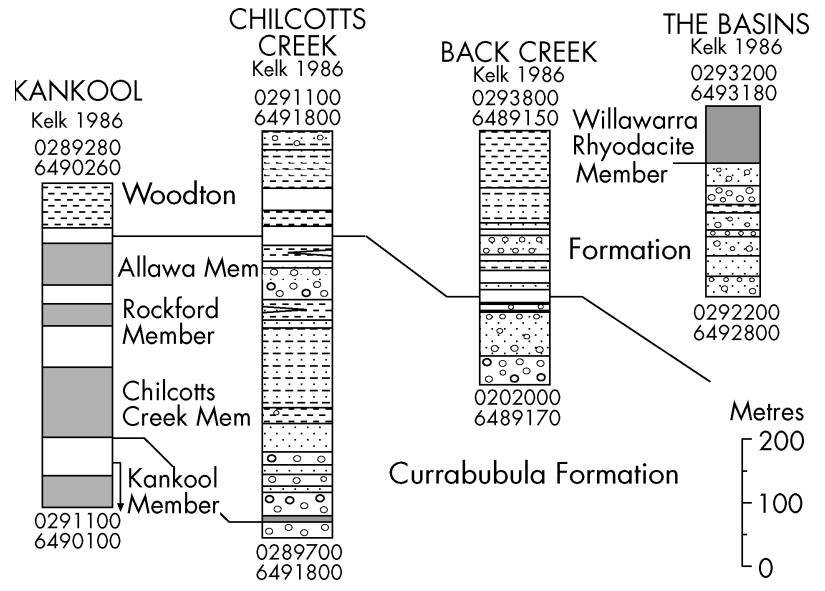

Figure 5 Stratigraphic sections measured by Kelk (1986) illustrating the succession between the Carboniferous Currabubula and earliest Permian (Asselian) Woodton Formations. The Back Creek section contains the type section and represents the lower part of the Woodton Formation. That from The Basins, from the upper part of the Woodton Formation, is designated as a subsidiary type section. See Figure 3 for legend. 
488-16c, Figure 12b), located $100 \mathrm{~m}$ higher in the sequence. Unnamed ignimbrite M4, a pink to purple, unwelded ignimbrite, is known only from a single belt of outcrop north of Waverley Pinnacle. Its extremities are defined by a cross fault in the north and the disconformity at the base of the Currabubula Formation in the south. Both the Wheelihans ignimbrite Member and unnamed ignimbrite Member M4 have an age of $c a 327 \mathrm{Ma}$.

\section{CURRABUBULA FORMATION}

The Currabubula Formation (Carey 1937; Voisey \& Williams 1964; McKelvey \& McPhie 1985) crops out on both limbs of the Werrie Syncline, in domal structures adjacent to the Mooki Thrust (Quirindi, and Castle Mountain Domes and Back Creek Anticline), and the eastern limb of the Temi Syncline (Plate 1). It extends $105 \mathrm{~km}$ from a faulted northern closure at Donnellys Gap (0270300E 6564500N Winton 1:25 000 sheet) south to the Waverley Fault (Plate 1). The Currabubula Formation disconformably overlies the Merlewood Formation and is disconformably overlain by the Lower Permian Woodton Formation, Temi Formation or Werrie Basalt. In the northern part of the Werrie block, the base of the Currabubula Formation was originally placed at the first appearance of boulder conglomerate, informally referred to the Porphyry Boulder Horizon (Carey 1937) and later named the Coeypolly Conglomerate Member
(Voisey \& Williams 1964). Porphyry boulders appear to extend southwards to the vicinity of Jacob and Joseph Creek, $8 \mathrm{~km}$ northwest of Wallabadah (Davies 1988; Dawson 1988). Although conglomerate is common in the basal parts of the Currabubula Formation in the Wallabadah-Waverley region, it is not possible to recognise the Coepolly Conglomerate Member as a discrete, mappable member.

In the region between Wallabadah and the Murrurundi Fault, granitic clasts are present in conglomerates in the upper part of the Merlewood and lower part of the Currabubula Formation. The base of the Currabubula Formations has been placed where there is an increase in the proportion of siliceous ignimbrite clasts and a change from a subdued to a steep topography produced by the more resistant nature of the sandstones and conglomerates. North of the Liverpool Range, this change takes place over a thickness of about $100 \mathrm{~m}$ (Figure 2, sections 502, 480). The boundary is more clearly delineated immediately south of the range (Figure 2, sections 465-466-469, 467). Between the Murrurundi and Waverley Faults, the boundary can also be recognised at the base of conglomerates overlying truncated beds of the Wheelihans Ignimbrite Member and unnamed ignimbrite M4. Schmedje (1984) reported abundant granitic clasts in the upper part of the of the Merlewood Formation, but a predominance of intermediate to acid volcanic clasts in the overlying Currabubula Formation between Burnewang (0313020E

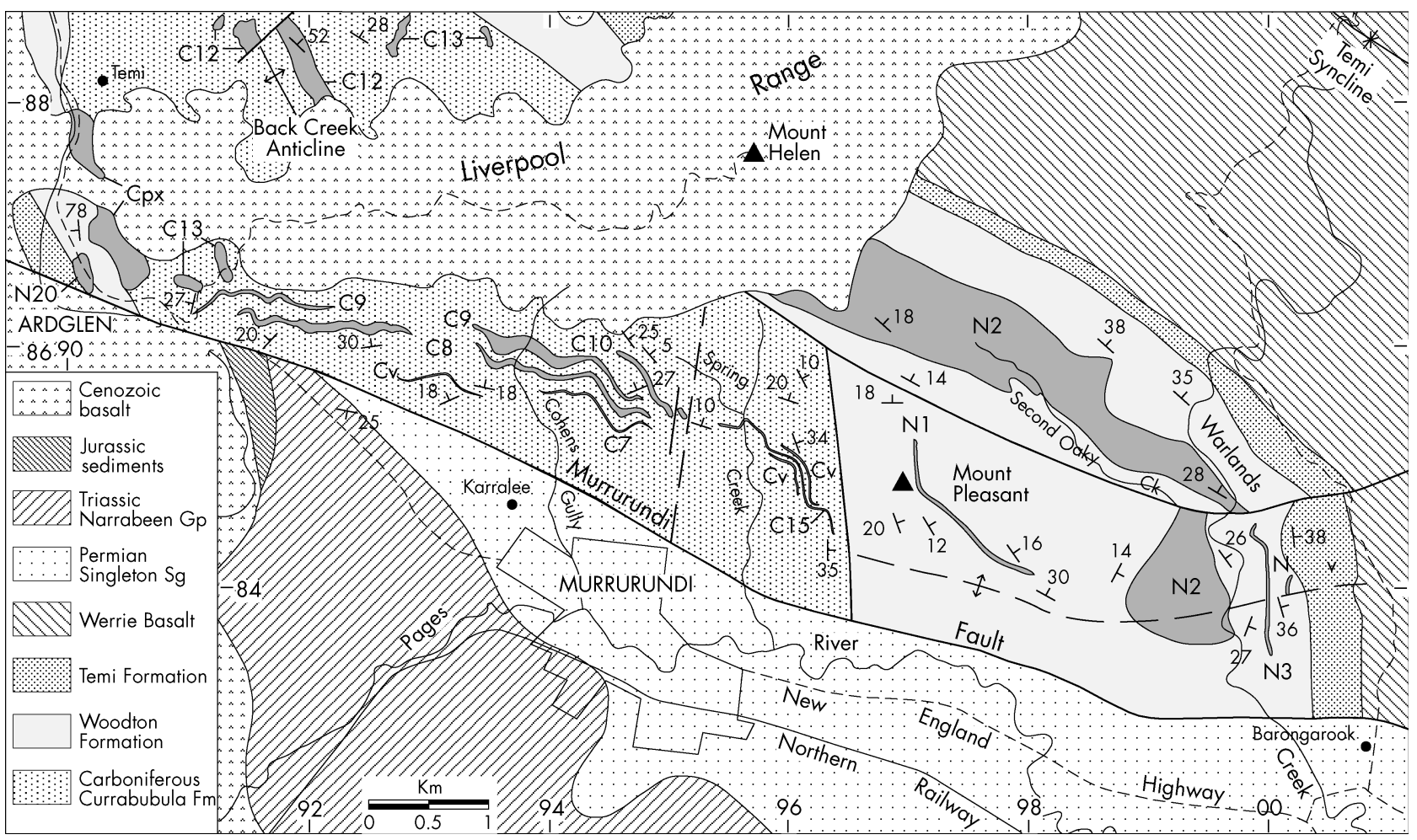

Figure 6 Geological map of the Murrurundi district illustrating the distribution of ignimbrites and lavas in the Upper Carboniferous Currabubula and lowest Permian (Asselian) Woodton Formations immediately north of the Murrurundi Fault. Volcanic members in the Currabubula Formation include Cv unnamed ignimbrites and lavas, C7 unnamed rhyodacite lava, C8 Murrurundi Ignimbrite Member, C9 Cohens Gully Ignimbrite Member, C10 Mt Helen Rhyodacite Member, Cpx unnamed pyroxene dacite, C12 Chilcotts Creek Ignimbrite Member, C13 Rockford Ignimbrite Member and C15 Karralee Ignimbrite Member. Those in the Woodton Formation include N1 Blandford Rhyodacite Member, N2 Warlands Creek Volcanic Member, N3 Barongarook Ignimbrite Member and Nv unnamed lava. 


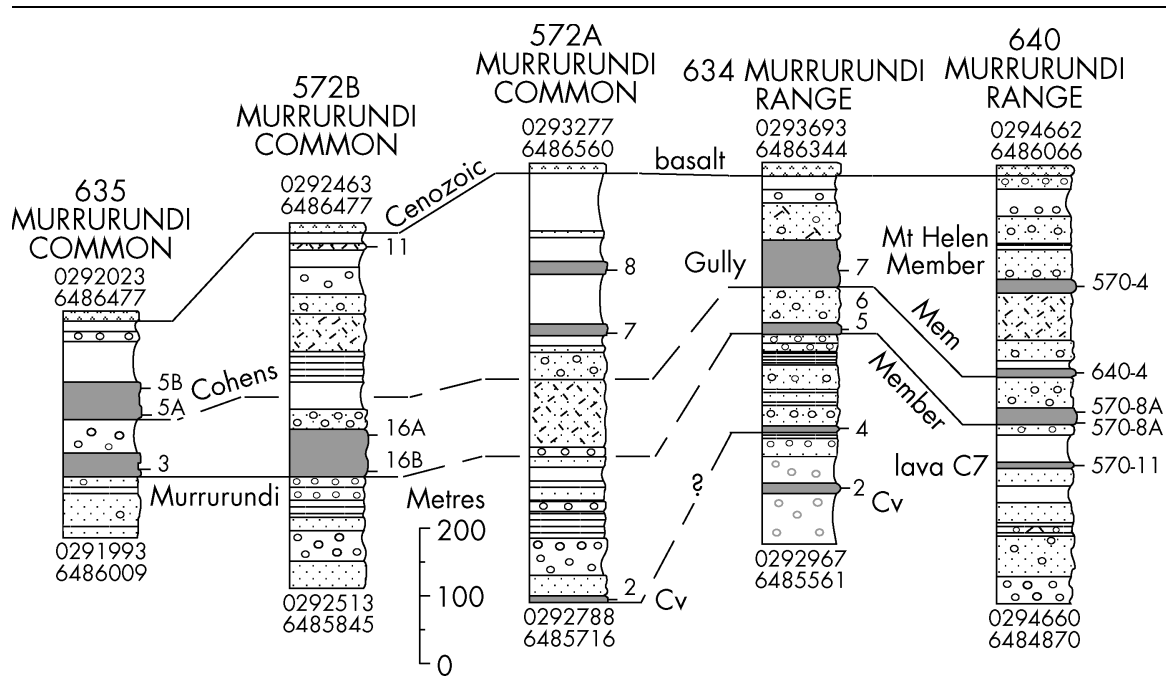

Figure 7 Measured stratigraphic sections from exposures of the Currabubula Formation between the Murrurundi Fault and the Liverpool Range. The absence of the Murrurundi and Cohens Gully Ignimbrite Members from section $572 \mathrm{~A}$ and the latter ignimbrite from section 572B illustrates a possible erosional channel. See Figure 3 for legend.
$6482100 \mathrm{~N})$ and Coogah (0311000E 647893N, both Timor 1:25 000 sheet) (Figure 3).

Major lithologies in the Currabubula Formation include extensive pebble to boulder conglomerate, volcanolithic sandstone (which is mainly coarse grained to gritty and frequently contains pebble stringers), siltstone, silty mudstone, varved shale, diamictite, ignimbrite and lava flows. They were derived from an erupting volcanic arc which was simultaneously being glaciated and eroded. The products of these processes were deposited in fluvial and lacustrine environments in adjacent western parts of the forearc basin (Whetten 1965; McKelvey \& McPhie 1985; McPhie 1987). Whilst resistant sandstone and conglomerate have produced a rugged landscape characterised by steep ridges and extensive cliff lines in the northern part of the Werrie Syncline, the Currabubula Formation in this region is more subdued than the partially equivalent Seaham Formation in the Rouchel block. A comparison of sections 465-466-468 (Figure 2) and 489-498-503 (Figure 3) suggests that the southernmost part of the formation has undergone more erosion than that immediately south of the Liverpool Range.

McPhie (1983) described the distribution of ignimbrites in the Currabubula Formation in the Werrie Syncline and Quirindi Dome and made correlations extending as far south as the Back Creek Anticline (Plate 1). She emphasised the importance of widespread superimposed disconformities in understanding the present distribution of ignimbrites in the formation. Disconformities also exist in the Currabubula Formation in eastern parts of the Wallabadah-Waverley district to the extent that only remnants of former ignimbrites are preserved. Volcanic units are more numerous in upper parts of the formation in the Back Creek Anticline and the Liverpool Range north of Murrurundi (Figures 4,6).

\section{Members of the Currabubula Formation}

Volcanic members of the Currabubula Formation vary laterally along the length of the Werrie block. Of the four major ignimbrite members identified by McPhie (1983) adjacent to the northern closure of the syncline and Quirindi Dome, only the Cana Creek Tuff Member extends into the southern part of the Werrie block, erosional remnants being found as far south as Chilcotts Creek, north of the Liverpool Range (Plate 1). Farther south, ignimbrites and lavas in the Currabubula Formation have a more limited extent, but in places are just as numerous. Channel-type erosion documented by McPhie (1983) in northern parts of the Werrie Syncline appears to extend southwards to the Liverpool Range as indicated by gaps in the Cana Creek Tuff Member (Plate 1).

\section{Eastern limb of Werrie Syncline and Castle Mountain Dome}

Two important members, the Cana Creek Tuff (McPhie 1983) and White Rocks Ignimbrite Members, are present in the north (Plate 1). The Cana Creek Tuff Member extends from the northern closure of the Werrie Syncline southwards to Chilcotts Creek. It consists of green, unwelded, ash-flow and air-fall pyroclastics and resedimented sandstone and siltstone. Two major outcrops of the tuff are present in the belt between the eastern margin of the Quipolly Dome and the Wallabadah district. Erosional remnants of the tuff are present both north and south of Big Double Mountain. In the Castle Mountain Dome, the Cana Creek Tuff is underlain by unnamed ignimbrite $\mathrm{C} 1$ (Appendix 1), also referred to as ignimbrite $\mathrm{Z}$ (McPhie 1983). The White Rocks Ignimbrite Member, a welded rhyodacitic ignimbrite with a vitrophyric base, overlies the Cana Creek Tuff Member in both regions. Outcrops of this ignimbrite occur adjacent to the Wallabadah-Quirindi road

Plate 1 Geological map of the western margin of the Tamworth Belt illustrating the geology of the southern part of the Werrie block and western part of the Rouchel block. The boundary between the two blocks, located along the Waverley Fault east of Wingen, seperates two different, but coeval, Carboniferous successions. The western margin of the Tamworth Belt is thrust over Permain rocks of the Sydney-Gunnedah Basin at the Mooki and Hunter Thrusts. Undifferentiated volcanics northwest of Quirindi have not been mapped in sufficient detail to be assigned to members of the Currabubula Formation. Black rectangles represent towns and villages, filled black circles homesteads, and black triangles prominent mountains. UR, Upper Rouchel; Ia, Isismurra; Ie, Isismede; E, Elmswood; MP, Mt Pleasant; WP, Waverley Pinnacle. 


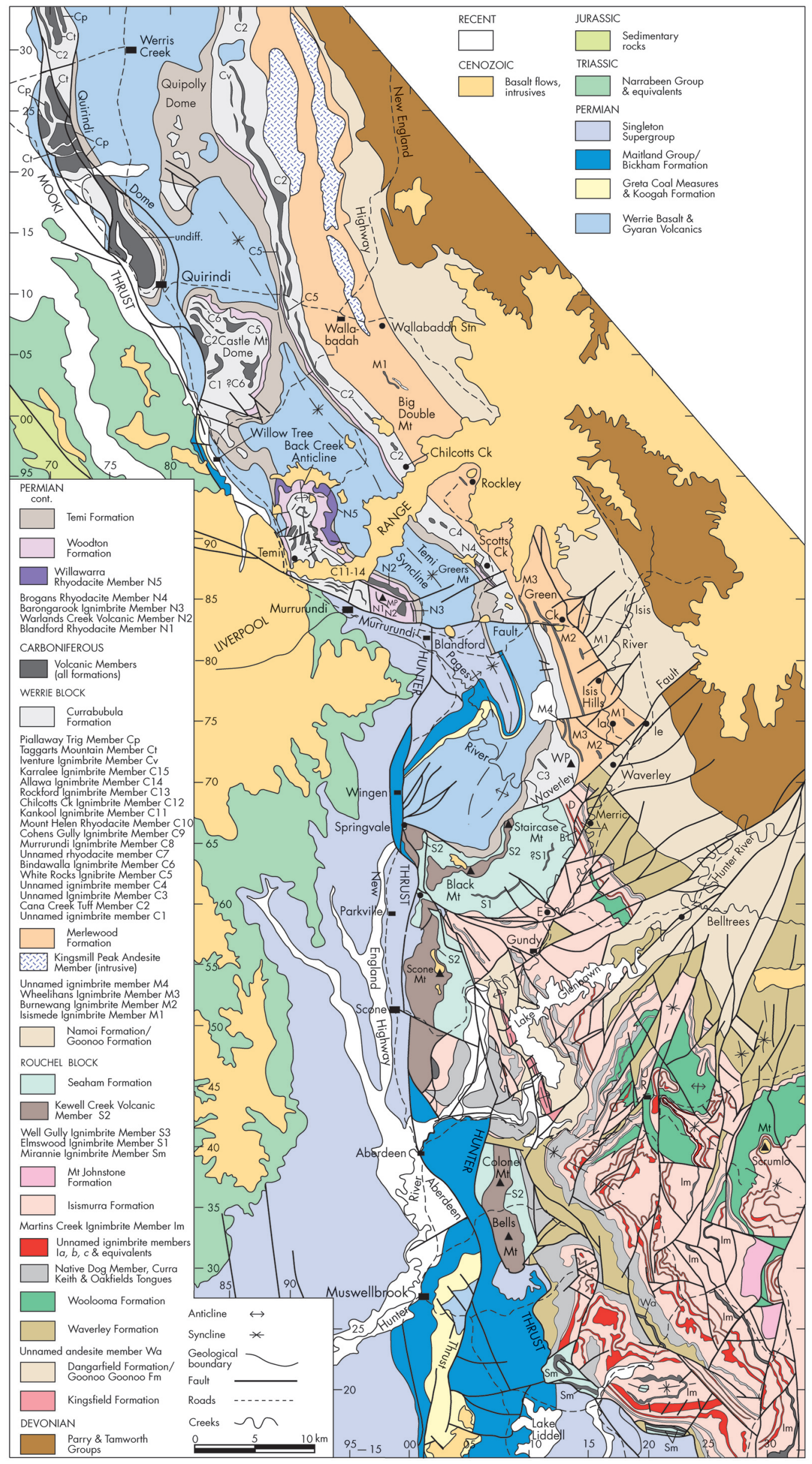


Figure 8 Measured stratigraphic sections of Currabubula Formation in the fault block between Spring Creek and the western margin of Mt Pleasant, and the Woodton Formation, Temi Formation and Werrie Basalt between Mt Pleasant and the Warlands Creek region. See Figure 3 for legend and Figure 6 for locations.

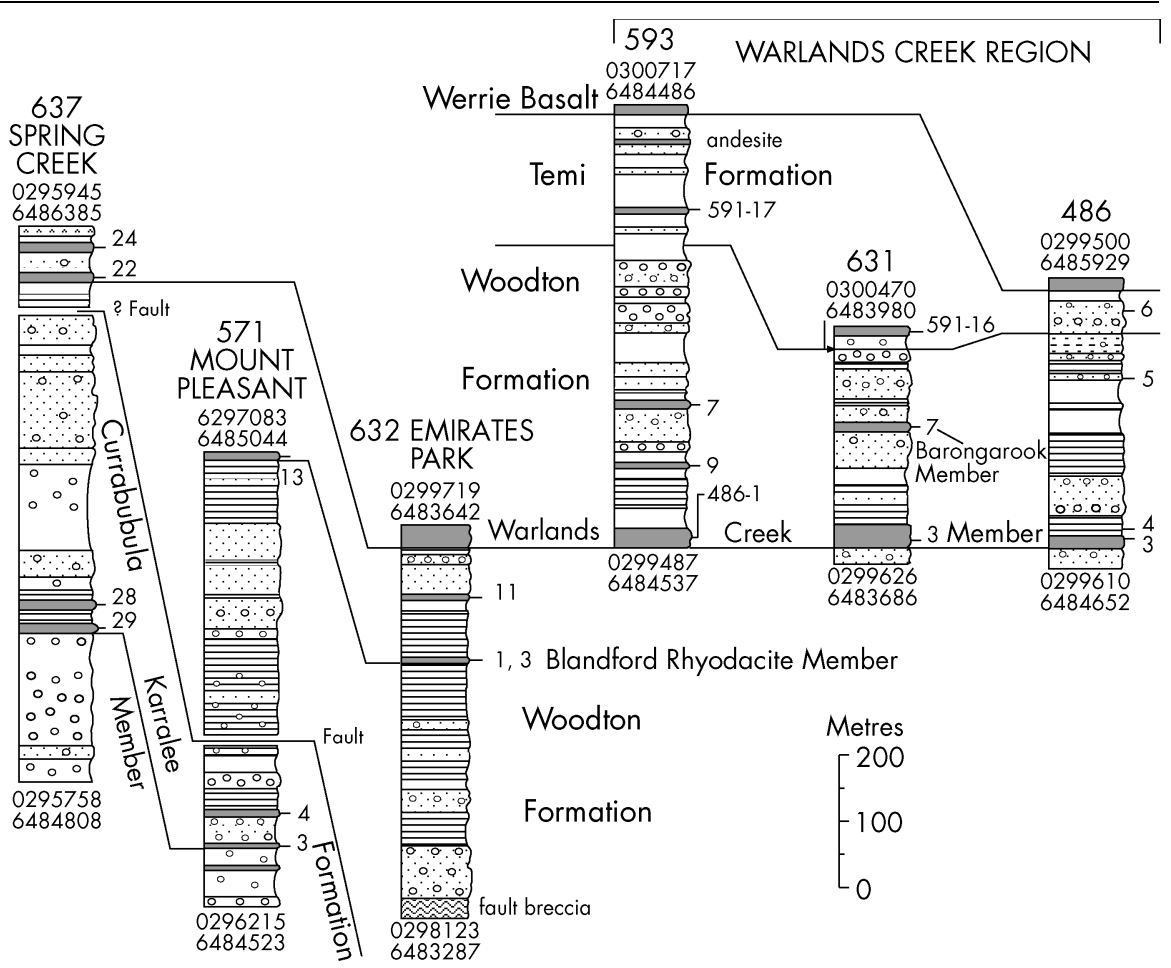

in the east and in the central part of Castle Mountain Dome. It has a SHRIMP AS3 age of $315.3 \pm 3.5 \mathrm{Ma}$ (sample 505-1, Figure 12e). At Bindawalla (0282000E $6508900 \mathrm{~N}$ Quirindi 1:25 000), in the Castle Mountain Dome, the White Rocks Ignimbrite Member is overlain by the Bindawalla Ignimbrite Member, a red to green unwelded ignimbrite.

South of the Liverpool Range, the Currabubula Formation contains the erosional remnants of two ignimbrites. Unnamed ignimbrite C3, a green to grey, unwelded ignimbrite, crops out west of Waverley Pinnacle $250 \mathrm{~m}$ below the preserved top of the formation; it has a SHRIMP AS3 age of 319.1 \pm 2.8 (sample 503-1, Figure 12c). Two outcrops containing unnamed ignimbrite C4, a brown, welded ignimbrite, are present $500 \mathrm{~m}$ below the top of the formation north of Greers Mountain. The SHRIMP AS3 age of ignimbrite C4 is $317.9 \pm 3.5$ Ma (sample 466-15. Figure 12d).

\section{Kankool-- Murrrurundi region}

In the Back Creek Anticline, east of Kankool (Figures 1, 4), a succession containing four rhyolitic pyroclastics, the Kankool, Chilcotts Creek, Rockford and Allawa Ignimbrite Members (Kelk 1986), is disconformably overlain by the Woodton Formation (Figures 4, 5). The ignimbrites crop out over an area of $\sim 6 \mathrm{~km}^{2}$ and are unknown elsewhere. SHRIMP AS3 dating of the Kankool and Allawa Ignimbrite Members gives ages in inverse stratigraphic order [308.9 $\pm 2.8 \mathrm{Ma}$ (sample 493-9, Figure 12f) and $311.5 \pm 2.9 \mathrm{Ma}$ (sample 493-3, Figure 13a)], suggesting that all four ignimbrites are around $310 \mathrm{Ma}$ old. The restricted occurrence of these members (Figure 4) could be due to erosion of the upper part of the formation elsewhere, or to a limited area of deposition. An unnamed pyroxene dacite located in a west-dipping succession near Ardglen (Kelk 1986) (Figure 4) may be in sequence with the rhyolitic ignimbrites. Contacts between the dacite and other rocks are obscured, preventing determination of whether it is a flow or a sill (Kelk 1986).

South of the Back Creek Anticline, a belt of Currabubula Formation occurs between Ardglen, the western margin of Mt Pleasant, and the Murrurundi Fault to the south. Faults on the western side of Mt Pleasant and in the vicinity of Second Oakey Creek separate the Currabubula and Woodton Formations (Figure 6). The belt of Currabubula Formation between Ardglen and Spring Creek contains three ignimbrites and two rhyodacite lavas. On the road to Mt Helen, the Cohens Gully Ignimbrite Member, the uppermost member at the western end of the range, underlies the Rockford Ignimbrite (Kelk 1986). This provides a link with the ignimbrite succession in the Back Creek Anticline and indicates that the succession on the southern margin of the Liverpool Range is older than $310 \mathrm{Ma}$. The lowest of the five flows mapped between the Mt Helen road and Spring Creek is an unnamed red ignimbrite cropping out $1 \mathrm{~km}$ northwest of Murrurundi township. North of the town, an unnamed beige to grey rhyodacite flow (C7) is present higher in the sequence, followed by two, substantial, red ignimbrites. The lower Murrurundi Ignimbrite Member is characterised by the rare occurrence of biotite and a groundmass that contains abundant vesicles and is frequently brick-red in colour. The succeeding Cohens Gully Ignimbrite Member is distinguished by its abundant biotite and paler pink to green colour. Towards the western end of the range, parts of both the Murrurundi and Cohens Gully Ignimbrite Members appear to have been removed by erosion (sections 572A, 572B, Figure 7). The uppermost Mt Helen Rhyodacite Member, a lava flow, is restricted 


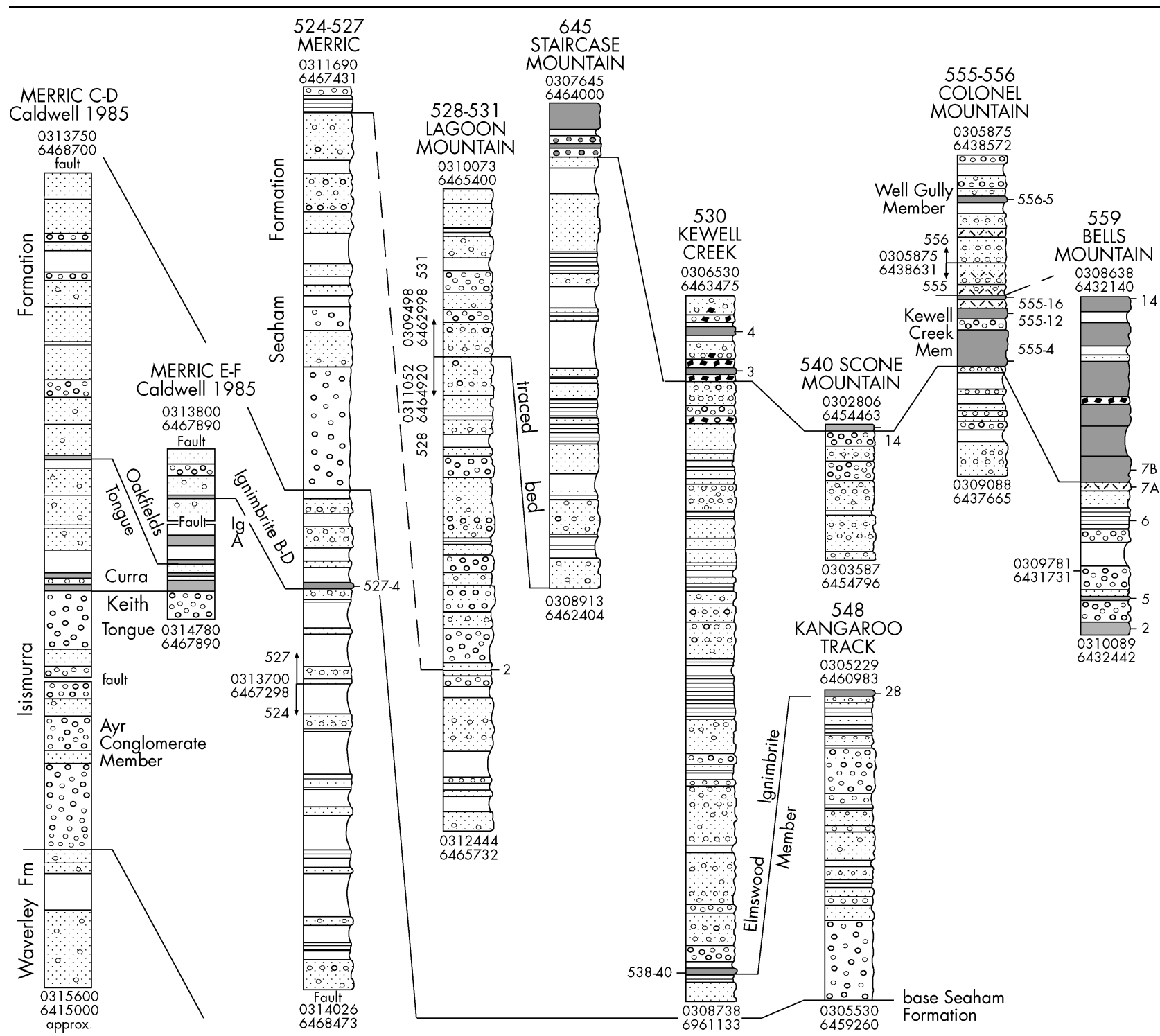

Figure 9 Measured stratigraphic sections from the Rouchel block illustrating the Carboniferous succession between the northern margin at the Waverley Fault and Bells Mountain, northeast of Muswellbrook. See Figure 3 for legend.

to a ridge crest in the mid-part of the range. Both rhyodacite lavas extend laterally for $<1 \mathrm{~km}$, whereas the two main red ignimbrites can be traced for almost $3 \mathrm{~km}$, although neither is continuous (Figure 6). The abrupt truncation of volcanic units north of Murrurundi township and repetition of a small distal part of the Mt Helen Rhyodacite Member suggest they are faulted in the east.

The fault block between Spring Creek and Mt Pleasant contains a different succession of the Currabubula Formation to that to the west. Areas of poor exposure, prolific scree and the possibility of additional faults prevent the establishment of a precise stratigraphic succession. That portrayed in Section 637 (Figure 8) covers the northern part of the block, southern parts being largely obscured by pebble and cobble scree. Section 637 was established from a traverse along a prominent ridge north of Spring Creek and appears to be cut in the north by the fault parallel with Second Oakey Creek (Figure 6); a possible second fault farther south is based on the truncation of prominent sandstone and conglomerate on the western slope of Mt Pleasant and the Karralee Ignimbrite Member towards the west (Figure 6). If this is the case, two different parts of the Currabubula Formation are represented in the lower and middle parts of Section 637 and the Woodton Formation in the uppermost part. The Karralee Ignimbrite Member, from the lower part of Section 637, is confined to the region between Spring Creek and Mt Pleasant. Rhyodacite flows of limited lateral extent both under and overlie the Karralee Ignimbrite Member adjacent to Spring Creek (Figure 6).

\section{WOODTON FORMATION (new name)}

The largely lacustrine Woodton Formation (Appendix 1) disconformably overlies the Currabubula Formation 


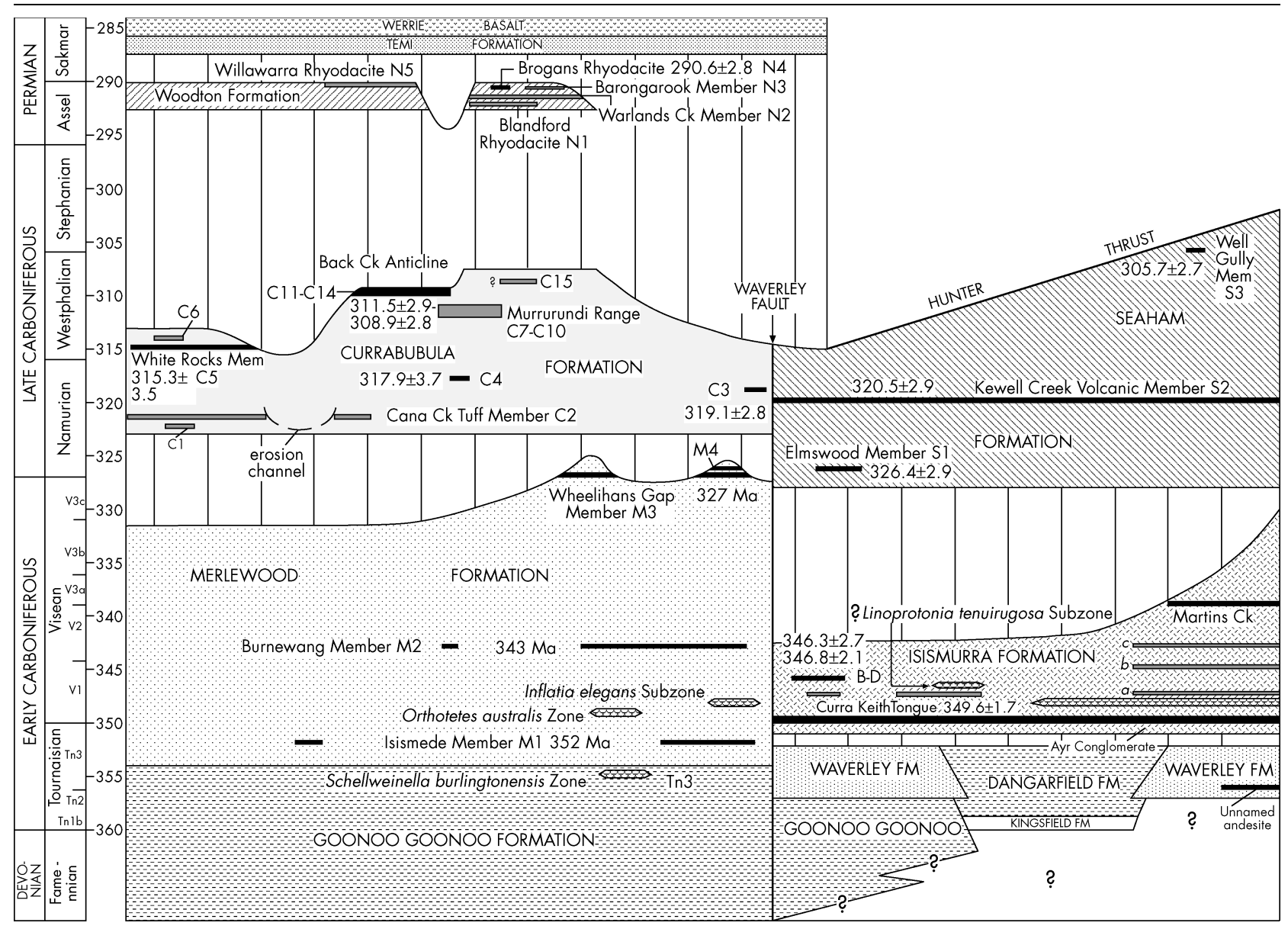

Figure 10 Time-space diagram of Carboniferous and Permian formations in the southern Werrie and Rouchel blocks. The diagram was constructed by projecting the distal limits of formations and members on to a line extending from the northern margin of the Castle Mountain Dome near Quirindi to the Waverley Fault and thence southwards to Bells Mountain (Plate 1). Time control is from SHRIMP AS3 dates and brachiopod zones from marine intercalations in the Merlewood and Isismurra Formations. SHRIMP SL13 dates for the Martins Creek Ignimbrite Member of the Isismurra Formation and an unnamed andesite from the Waverley Formation (Roberts et al. 1995a) have been increased in age by $2 \%$ following Black et al. (2003a). Volcanic members dated by SHRIMP are shown in black and undated units in grey. The Carboniferous time-scale has been modified at the Tournaisian-Visean boundary to accommodate the SHRIMP AS3 age of the Curra Keith Tongue, used to calibrate the international boundary between the Tournaisian and Visean Stages (Roberts et al. 1995a). The base of the Carboniferous is taken at 360 Ma following Trapp et al. (2004), who redated the two metabentonite beds 70 and 79 in the Hasselbachtal auxiliary global stratotype in Sauerland, Germany, rather than the 362 Ma age proposed by Williams et al. (2000).

and is overlain disconformably by the Lower Permian Temi Formation. Although previously mapped as a member of the Currabubula Formation, it is now known to be earliest Permian (Asselian) in age (Appendix 1). The formation is confined to the region between the Quipolly Dome and the Murrurundi Fault. Extensive outcrops are present in the Castle Mountain Dome, Back Creek Anticline and both limbs of the Temi Syncline (Figures 2, 5, 7). Two small inliers identified by Lowe (1971), too small to be shown in Plate 1, occur on an unnamed tributary of Borambil Creek, $1.5 \mathrm{~km}$ northwest of the closure of the back Creek Anticline and $4 \mathrm{~km}$ east of Willow Tree. The formation is characterised by laminated, or massive mudstone and siltstone, graded volcanolithic siltstone and sandstone, all of which may contain dropstones, conglomeratic debris flows and sandy diamictite (Kelk 1986). Multicoloured ash-rich siltstone is present at the northern and southern extremities of the member. In the Quipolly district, ash-rich siltstone is accompanied by mudstone and intraformational breccias.

Volcanic rocks are present in the Woodton Formation only in the Scotts Creek and Warlands Creek regions near Murrurundi and the northern closure and flanks of the Back Creek Anticline. At Scotts Creek, the Brogans Rhyodacite Member (Manser 1968) is interbedded with multicoloured siltstone, volcanolithic sandstone and pebble to cobble conglomerate. The rhyodacite, a red to pink lava flow with small flow folds, is known only from between the southeastern margin of Greers Mountain and the hillside immediately east of the nearby Scotts Creek. The SHRIMP AS3 age of $294.1 \pm 3.6 \mathrm{Ma}$ is earliest Permian (Asselian) (Sample 287-2A, Figure 13b). Small faults subparallel with a fracture extending from the east-northeasttrending axial region of the Temi Syncline displace 
Table 1 SHRIMP sample localities.

\begin{tabular}{|c|c|c|c|c|}
\hline Sample & Unit or Member & Grid reference & 1:25 000 sheet & Age (Ma) \\
\hline 284-2 & Kewell Creek Volcanics & $0308600 \mathrm{E} 6461200 \mathrm{~N}$ & Parkville 9034-2-S & $320.5 \pm 2.8$ \\
\hline $287-2 \mathrm{~A}$ & Brogans Rhyodacite & 0306450E $6486320 \mathrm{~N}$ & Temi 9034-1-S & $290.5 \pm 2.8$ \\
\hline $456-13 \mathrm{~A}$ & Burnewang Ignimbrite & 0304076E $6494394 \mathrm{~N}$ & Temi 9034-1-S & $343.0 \pm 3.0$ \\
\hline $466-15$ & Unnamed ignimbrite C4 & 0301627E $6491305 \mathrm{~N}$ & Temi 9034-1-S & $317.9 \pm 3.5$ \\
\hline $469-43$ & Wheelihans Ignimbrite & $0309515 \mathrm{E} 6484148 \mathrm{~N}$ & Murrurundi 9034-2-N & $327.4 \pm 3.7$ \\
\hline $470-13$ & Isismede Ignimbrite & 0314091E $6480509 \mathrm{~N}$ & Timor 9134-3-N & $352.4 \pm 3.0$ \\
\hline $472-1$ & Burnewang Ignimbrite & $0312374 \mathrm{E} 6481037 \mathrm{~N}$ & Timor 9134-3-N & $342.4 \pm 3.3$ \\
\hline $488-2 \mathrm{~A}$ & Burnewang Ignimbrite & 0315974E $6474511 \mathrm{~N}$ & Timor 9134-3-N & $348.9 \pm 2.9$ \\
\hline $488-16 \mathrm{C}$ & Unnamed ignimbrite M4 & 0312899E $6472910 \mathrm{~N}$ & Timor 9134-3-N & $328.1 \pm 2.9$ \\
\hline $490-2$ & Isismede Ignimbrite & 0318577E $6474636 \mathrm{~N}$ & Timor 9134-3-N & $355.5 \pm 2.0$ \\
\hline 493-3 & Allawa Ignimbrite & $0290289 \mathrm{E} 6490848 \mathrm{~N}$ & Temi 9034-1-S & $311.5 \pm 2.9$ \\
\hline $493-9$ & Kankool Ignimbrite & 0291334E $6489673 \mathrm{~N}$ & Temi 9034-1-S & $308.9 \pm 2.8$ \\
\hline $501-4$ & Isismede Ignimbrite & 0297700E $6504300 \mathrm{~N}$ & Wallabadah 9034-1-N & $351.7 \pm 3.2$ \\
\hline $503-1$ & Unnamed ignimbrite C3 & 0310692E $6471463 \mathrm{~N}$ & Parkville 9034-2-S & $319.1 \pm 2.9$ \\
\hline $505-1$ & White Rocks Ignimbrite & $0289706 \mathrm{~N} 6507911 \mathrm{~N}$ & Wallabadah 9034-1-N & $315.3 \pm 3.5$ \\
\hline $527-24$ & Unnamed ignimbrite D & 0313522E $6467004 \mathrm{~N}$ & Waverley 9134-3-S & $346.8 \pm 2.1$ \\
\hline $532-1 \mathrm{~A}$ & Unnamed ignimbrite B & $0313843 \mathrm{~N} 6466452 \mathrm{~N}$ & Waverley 9134-3-S & $346.3 \pm 2.7$ \\
\hline $538-40$ & Elmswood Ignimbrite & $0308448 \mathrm{~N} 6461072 \mathrm{~N}$ & Parkville 9034-2-S & $326.4 \pm 2.6$ \\
\hline $542-1$ & Curra Keith Tongue & $0315146 \mathrm{~N} 6464075 \mathrm{~N}$ & Waverley 9134-3-S & $349.6 \pm 1.7$ \\
\hline $556-5$ & Well Gully Ignimbrite & $0306282 \mathrm{~N} 6438112 \mathrm{~N}$ & Aberdeen 9033-1-S & $305.7 \pm 2.7$ \\
\hline
\end{tabular}

dextrally the Brogans Rhyodacite Member in the region east of Scotts Creek (Plate 1). Erosion prior to deposition of the Temi Formation appears to have removed the member southeast of locality $642-7$ (0306824E $6485556 \mathrm{~N}$ Temi 1:25 000 sheet) in this region.

On the western limb of the Temi Syncline, east of Murrurundi, there is a continuous, although disconformable, succession from the Woodton Formation into the Sakmarian Temi Formation and Werrie Basalt (Figure 6). The main succession (sections 571, 632, Figure 8), which is faulted against the Currabubula Formation, extends eastwards from Mt Pleasant. It consists of diamictite, grey to beige siltstone, volcanolithic sandstone and minor interbedded conglomerate. The overlying Blandford Rhyodacite Member is a beige to grey rhyodacite flow which extends for $2 \mathrm{~km}$. Beige siltstone, an unnamed second rhyodacite flow (section 632-11, Figure 8) (0298500E 6484191N Murrurundi 1:25000 sheet), volcanolithic sandstone, and pebble conglomerate are present beneath the Warlands Creek Volcanic Member, one of the most extensive volcanic units in the Liverpool Range (Plate 1, Figure 6). In the vicinity of Warlands Creek, the member consists predominantly of a beige to grey welded ignimbrite (Appendix 1). West of Warlands Creek and north of Second Oakey Creek, this ignimbrite decreases in significance and is replaced by lava flows and resedimented sandstone (Appendix 1).

East of Warlands Creek gorge, above the Warlands Creek Member, as many as three separate volcanic units are interbedded in a sequence of grey, siliceous siltstone, volcanolithic sandstone and conglomerate (section 593, Figure 8). Only the Barongarook Ignimbrite Member, a beige, unwelded ignimbrite is mappable. Rhyodacite flows of limited lateral extent are present $\sim 50 \mathrm{~m}$ above the Warlands Creek Member (Figure 8, locality 631-6, 0299749E 6483765N Temi 1:25 000 sheet) and above the Barongarook Ignimbrite Member (localities $643-9,643-10,0299965 \mathrm{E} 6484181 \mathrm{~N}$ to $0300194 \mathrm{E} 6484084 \mathrm{~N}$
Murrurundi 1:25000 sheet). Conglomerate containing large fragments of silicified wood signifies the boundary between the Woodton Formation and the Temi Formation in the region east of Warlands Creek (0300300E 6484020N Murrurundi 1:25 000 sheet). Pale-grey andesitic lava near the base of the Temi Formation is followed by coarse, beige to white lithic sandstone. The sandstone is quartz-poor and contains grains of fine-grained intermediate volcanics and devitrified ignimbrites, the latter probably of Carboniferous origin.

In the Back Creek Anticline, the Willawarra Rhyodacite Member at the top of the Woodton Formation (Figures 4,5) is disconformably overlain by the Lower Permian Temi Formation or Werrie Basalt. It consists of at least two flows of finely flow-banded lava and minor breccia (Kelk 1986).

\section{Rouchel block}

The Rouchel block is located between the Waverley Fault in the north, the Hunter Thrust in the west and south, and the Karrakurra Fault system in the east (Roberts et al. 1991). A detailed description of the Carboniferous stratigraphy of the block has been given by Roberts and Oversby (1974) and Roberts et al. (1991). The succession has an overall sequential and lithological similarity with that in the adjoining Werrie block, but in detail there are substantial differences. The basal Tournaisian Kingsfield Formation, known only from a limited region adjacent to Lake Glenbawn (Plate 1), contains marginal-marine to continental volcanolithic sedimentary rocks and pyroclastics (Roberts \& Oversby 1974; Mory 1978; Mory \& Crane 1982). It is equivalent to marine mudstones and siltstones north of Belltrees (Saxton 1984; Roberts et al. 1991) included in the Parry Group (Plate 1). Overlying the Kingsfield Formation are marine sandstones, the Brushy Hill Limestone Member, and a thick succession of fossiliferous mudstone of the 

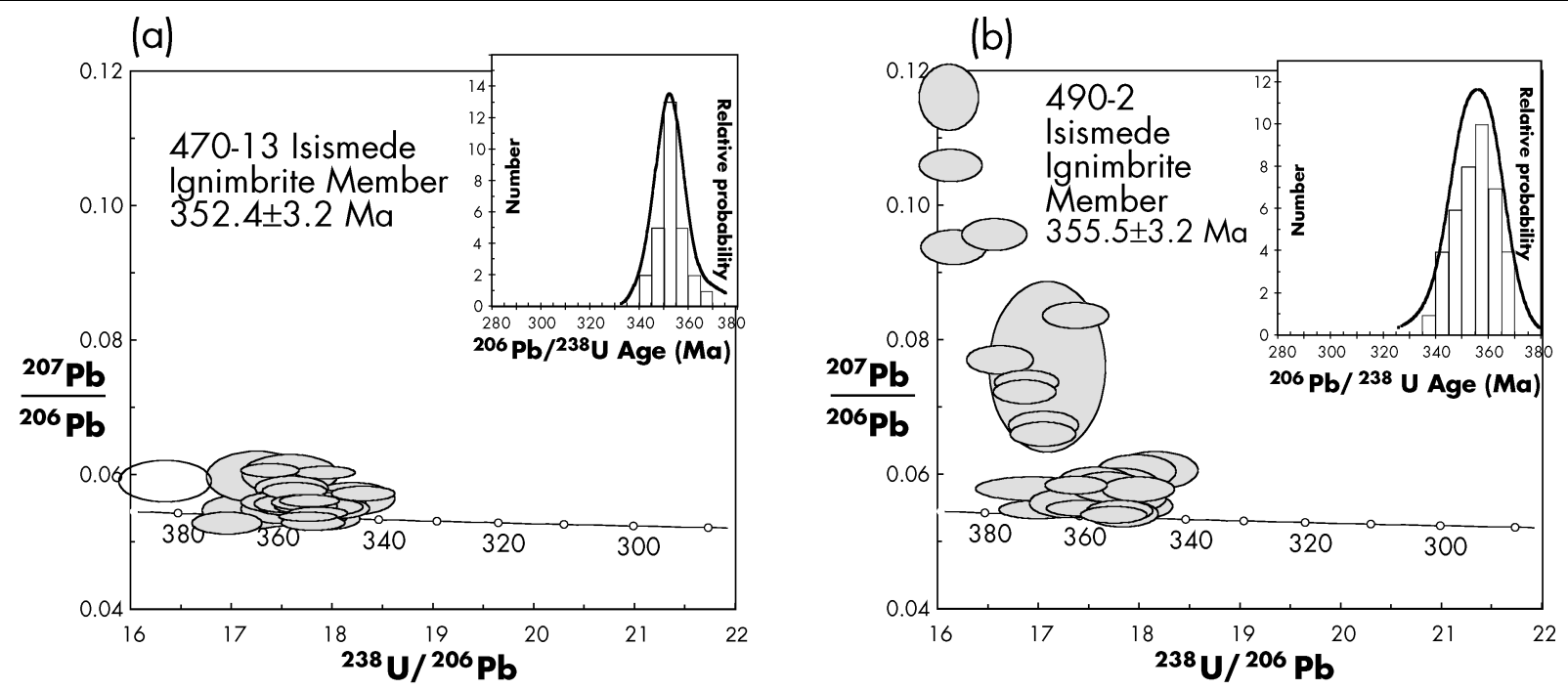

(c)

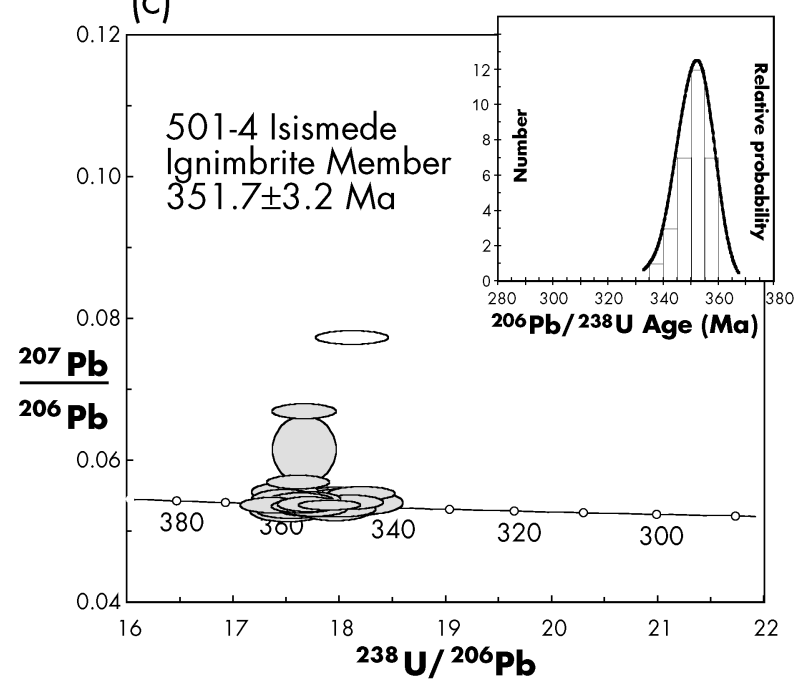

(d)

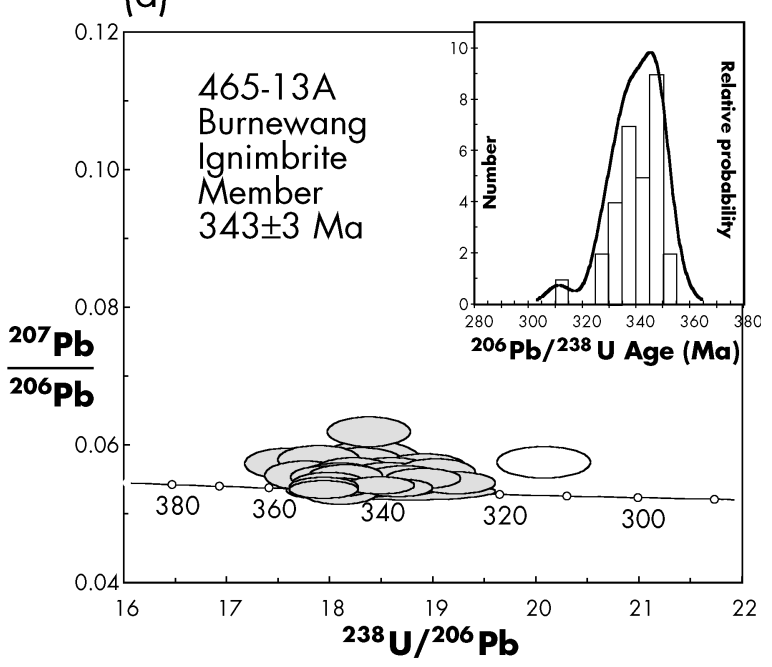

(e)
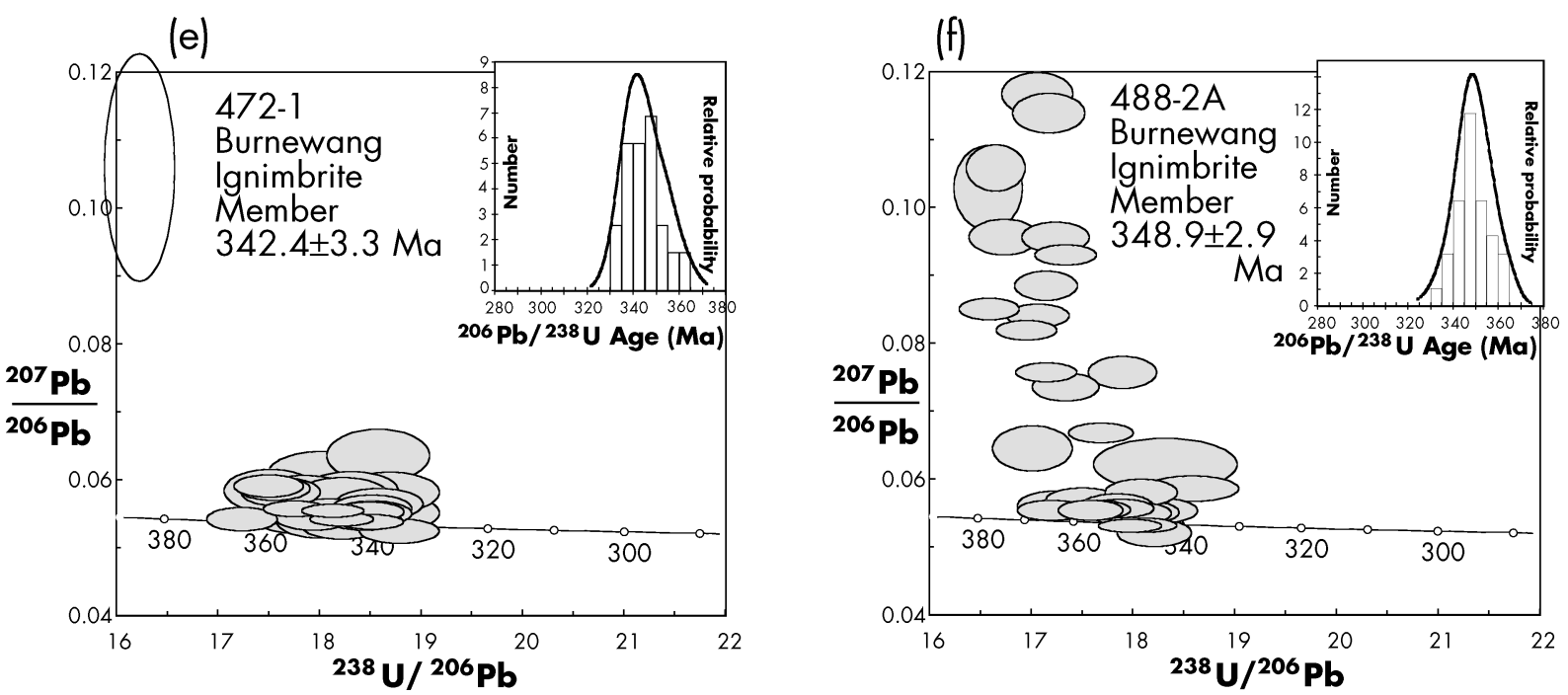

Figure 11 Tera and Wasserburg concordia plots (Tera \& Wasserburg 1972) of the calibrated total ${ }^{238} \mathrm{U} /{ }^{206} \mathrm{~Pb}$ ratios $v s$ the total ${ }^{207} \mathrm{~Pb} /{ }^{206} \mathrm{~Pb}$ ratio. Analyses plotted as $1 \sigma$ error ellipses. The inset is a probability density plot with stacked histogram; analyses used for the weighted mean ${ }^{206} \mathrm{~Pb} /{ }^{238} \mathrm{U}$ age calculation are shaded. The age uncertainty is given at $95 \%$ confidence limits and includes the uncertainty in the $\mathrm{U} / \mathrm{Pb}$ ratio calibration of the reference zircon. Plots and calculations based on ISOPLOT of Ludwig (1999). All samples are from the Merlewood Formation, southern Werrie block. (a) Sample 470-13, Isismede Ignimbrite Member; (b) Sample 490-2, Isismede Ignimbrite Member; (c) Sample 501-4, Isismede Ignimbrite Member; (d) Sample 465-13A, Burnewang Ignimbrite Member; (e) Sample 472-1, Burnewang Ignimbrite Member; (f) Sample 488-2A, Burnewang Ignimbrite Member. 

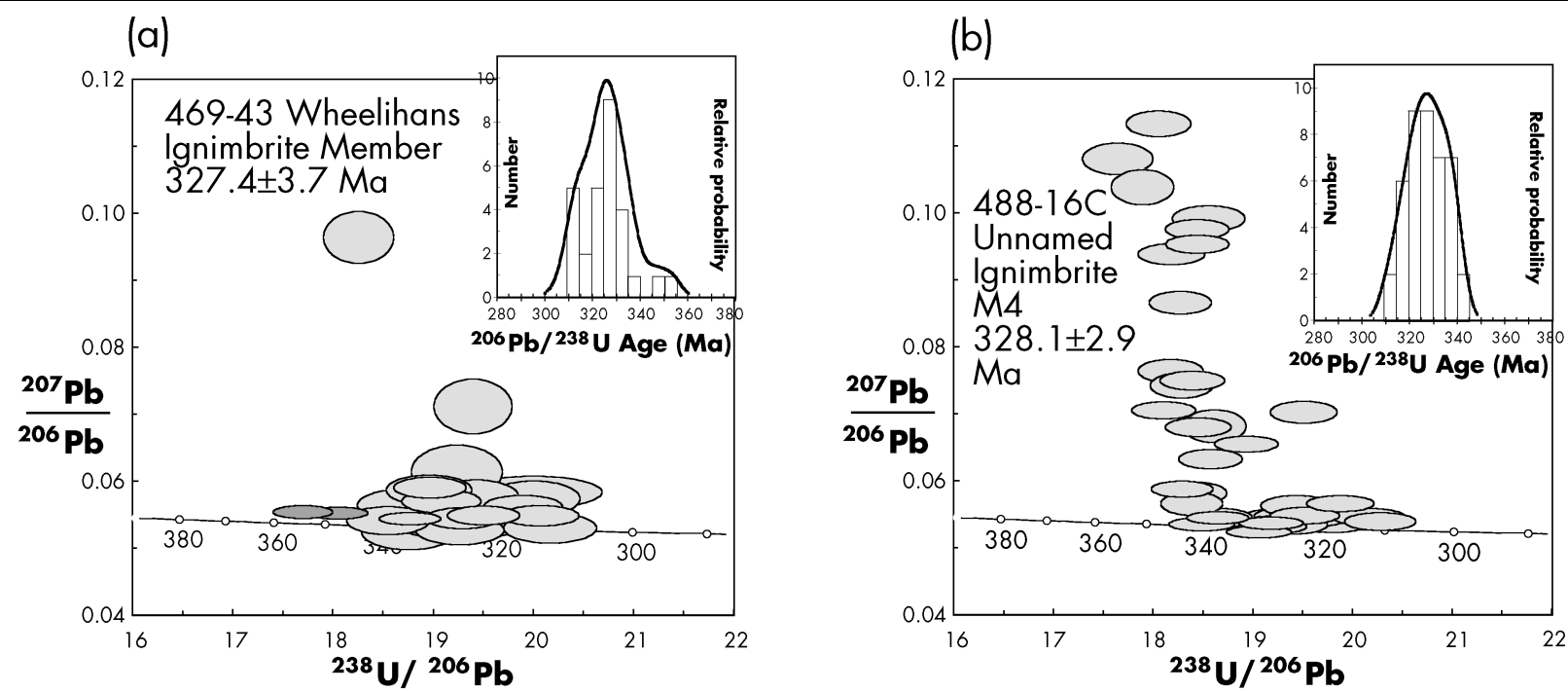

(c)

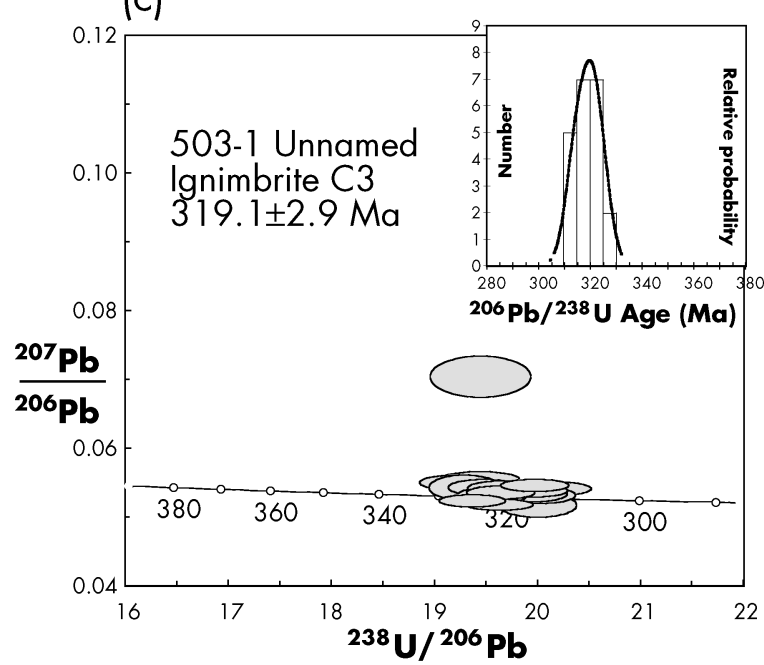

(d)

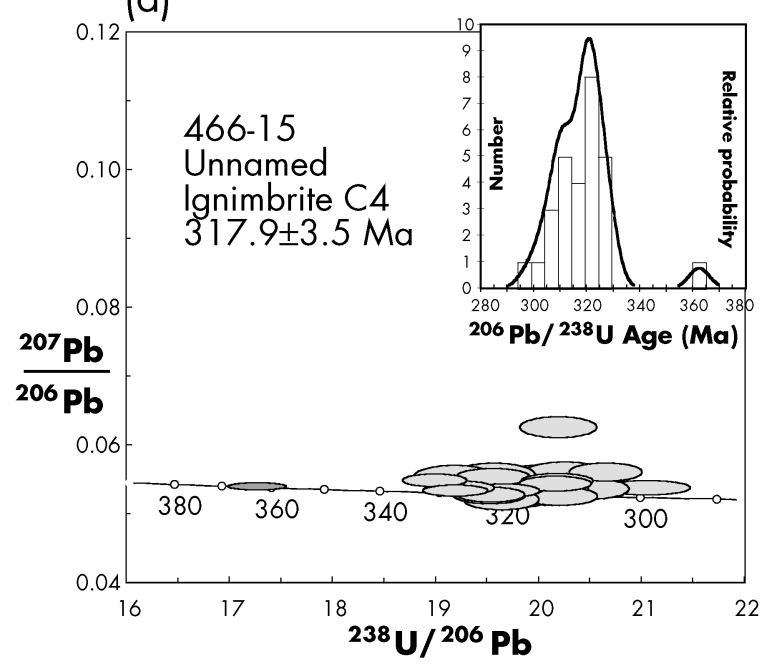

(e)

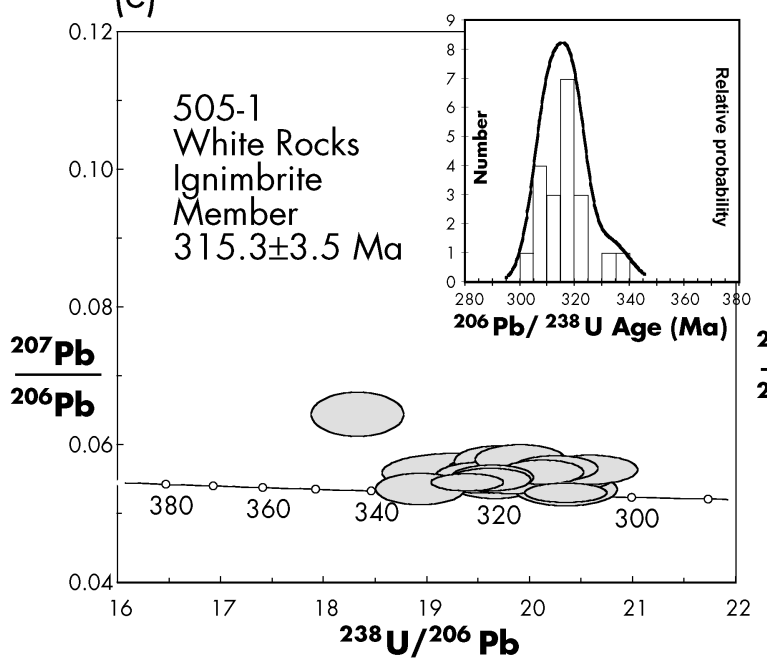

(f)

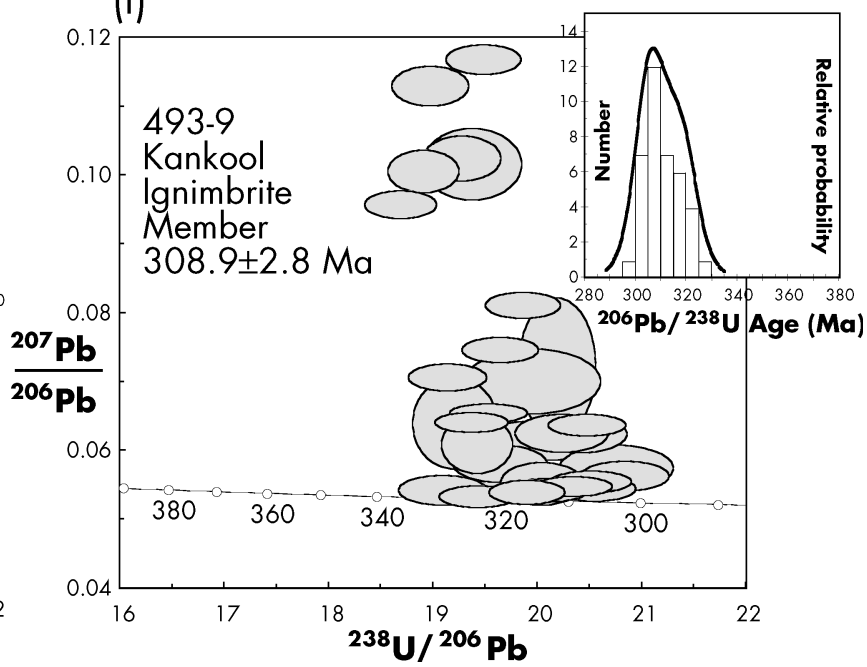

Figure 12 Tera and Wasserburg concordia plots of the calibrated total ${ }^{238} \mathrm{U} /{ }^{206} \mathrm{~Pb}$ ratios $v s$ the total ${ }^{207} \mathrm{~Pb} /{ }^{206} \mathrm{~Pb}$ ratio $(\mathrm{see}$ Figure 11 caption for details). (a) Sample 469-43, Wheelihans Gap Ignimbrite Member; (b) Sample 488-16C, unnamed Ignimbrite M4, both Merlewood Formation; (c) Sample 503-1, unnamed ignimbrite C3; (d) Sample 466-15, unnamed ignimbrite C4; (e) Sample 505-1, White Rocks Ignimbrite Member; (f) Sample 493-9, Kankool Ignimbrite Member; (c) to (f) from the Currabubula Formation. 

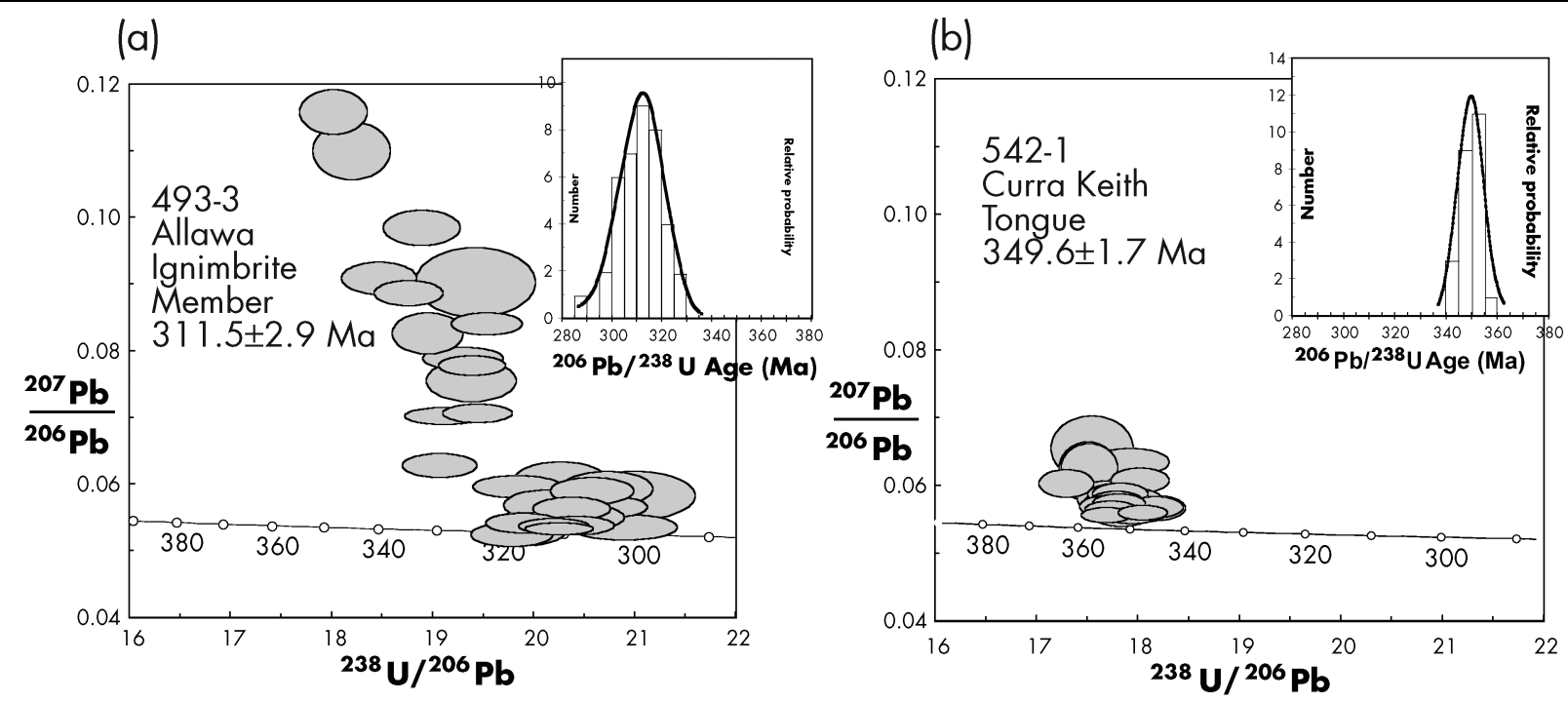

(c) $287-2$ A Brogans Rhyodacite

(d)
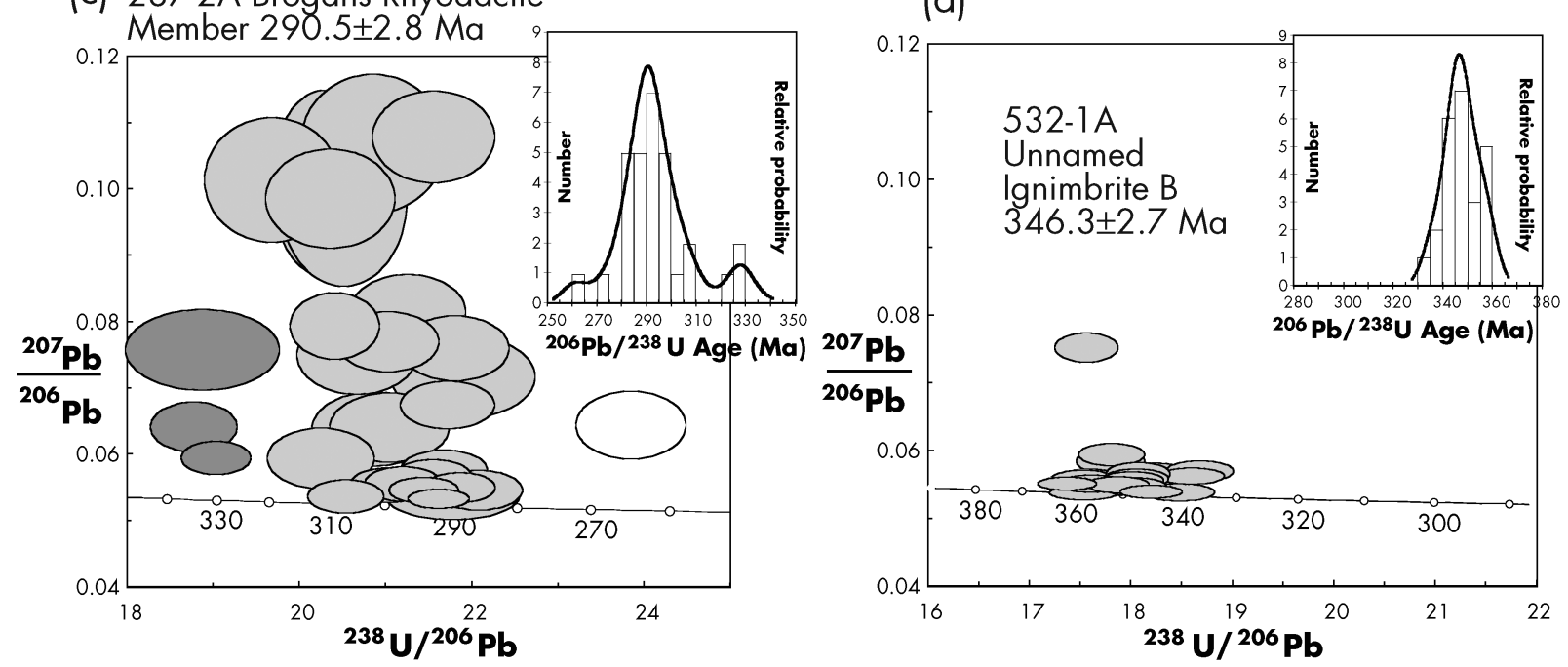

(e)
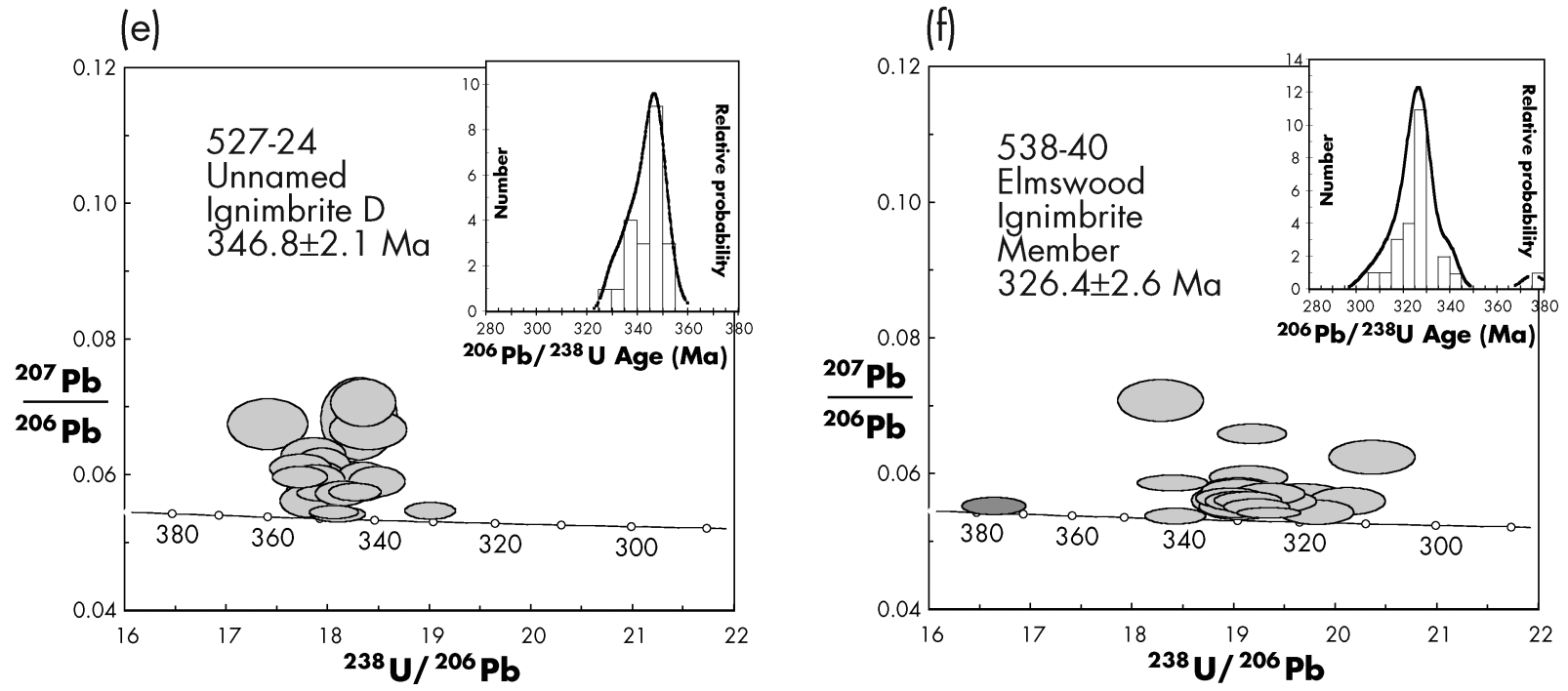

Figure 13 Tera and Wasserburg concordia plots of the calibrated total ${ }^{238} \mathrm{U} /{ }^{206} \mathrm{~Pb}$ ratios $v s$ the total ${ }^{207} \mathrm{~Pb} /{ }^{206} \mathrm{~Pb}$ ratio $(\mathrm{see}$ Figure 11 caption for details). (a) Sample 493-3, Allawa Ignimbrite Member, Currabubula Formation; (b) Sample 542-1, Curra Keith Tongue of the Native Dog Member, Isismurra Formation; (c) 287-2A, Brogans Ignimbrite Member, Woodton Formation; (d) Sample 532-1A, unnamed ignimbrite B, Isismurra Formation; (e) Sample 527-24, unnamed ignimbrite D, Isismurra Formation; (f) Sample 538-40, Elmswood Ignimbrite Member, Seaham Formation. 

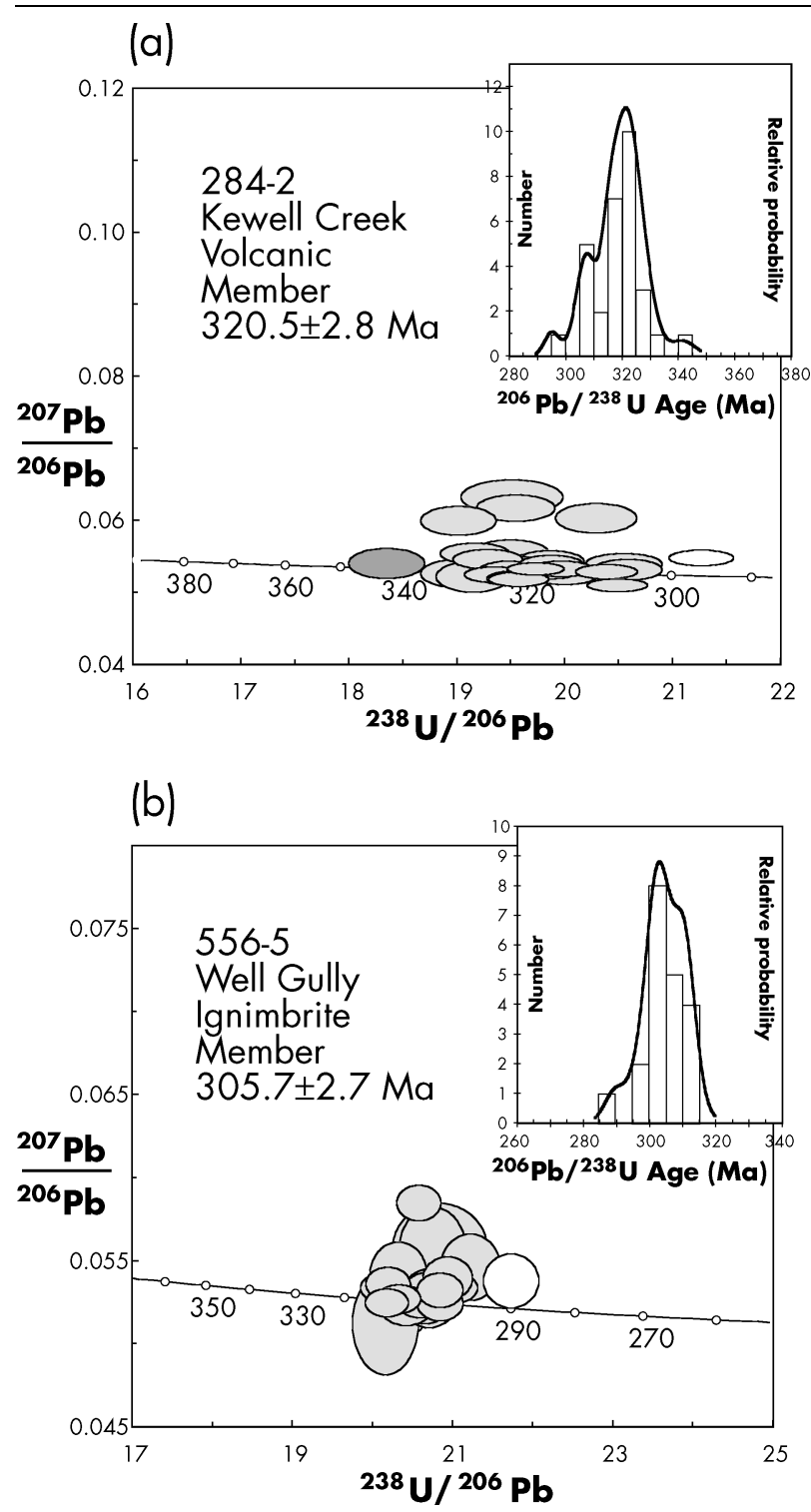

Figure 14 Tera and Wasserburg concordia plots of the calibrated total ${ }^{238} \mathrm{U} /{ }^{206} \mathrm{~Pb}$ ratios $v s$ the total ${ }^{207} \mathrm{~Pb} /{ }^{206} \mathrm{~Pb}$ ratio (see Figure 11 caption for details). (a) Sample 284-2, Kewell Creek Volcanic Member; (b) Sample 556-5, Well Gully Ignimbrite Member; both Seaham Formation.

Dangarfield Formation. This localised, shelfal mudstone intertongues northeastwards with mudstones of the Goonoo Goonoo Formation, and towards the north east and south with both marine and non-marine parts of the Tournaisian Waverley Formation (Roberts \& Oversby 1974; Roberts et al. 1991).

A hiatus between the Tournaisian and Visean successions throughout much of the Rouchel block is recognised beneath the Ayr Conglomerate Member of the Isismurra Formation (Roberts \& Oversby 1974). The overlying coarse volcanolithic sediments contain ignimbrites of the Native Dog Member and its Curra Keith and Oakfields Tongues, three unnamed red ignimbrites (Roberts \& Oversby 1974), and the Martins Creek Ignimbrite Member (Roberts et al. 1991). North and east of Upper Rouchel, the medial part of the Isismurra Formation intertongues with the marine Woolooma Formation containing fossiliferous siltstone, mudstone, sandstone and minor bioclastic limestone (Roberts \& Oversby 1974; Saxton 1984) (Plate 1). The marine intercalation occurs stratigraphically above the Oakfields Tongue of the Isismurra Formation. In the vicinity of Upper Rouchel, it contains brachiopod faunas of the Inflatia elegans Subzone (Delepinea aspinosa Zone) and $10 \mathrm{~km}$ east of Upper Rouchel the Orthotetes australis Zone and Inflatia elegans Subzone. The northernmost belt of Woolooma Formation between a major fault $4.5 \mathrm{~km}$ west of Belltrees and the Isis River contains a trilobite restricted to the younger Linoprotonia tenuirugosa Subzone (Saxton 1984). Upper Carboniferous rocks between the Waverley Fault and Muswellbrook, referred either to the Rossmore Formation (Manser 1968) or undivided Carboniferous and Permian rocks (Roberts \& Oversby 1974), are identified as Seaham Formation. This succession disconformably overlies the Isismurra Formation and contains rhyodacitic ignimbrites comparable with those in the Seaham Formation on the southern margin of the Rouchel Block (Roberts et al. 1991: Camberwell 1:100 000 sheet), the Mt View region (Brakel 1972), the Cranky Corner Basin (Stevenson 2003) and the southern margin of the Gresford block (Browne 1926). The Mirannie and Elmswood Ignimbrite Members are approximately the same age, when SHRIMP dates based on the SL13 and AS3 standards are corrected by either $+1 \%$ or $-1 \%$, respectively, to bring them to an approximate equivalence with the Temora 1 standard (Black et al. 2003b); they could therefore be the same unit. The Kewell Creek Volcanic Member, which extends southwards from the Waverley Fault and Black Mountain region to Bells Mountain, is comparable with agglomeratic units in the Hebden Thrust block (Brakel 1972) (Plate 1). Both the Mirannie Ignimbrite Member and rocks in the Hebden Thrust block belong to the Seaham Formation (Roberts et al. 1991).

\section{ISISMURRA FORMATION}

Comprehensive descriptions of the Isismurra Formation have been given by Roberts and Oversby (1974) and Roberts et al. (1991). Designation of a formal type section is possible now that the region between the Waverley Fault and Wallabadah has been remapped. This is formalised in Appendix 1. Stratigraphic sections measured through the Isismurra Formation and overlying Currabubula Formation are given in Figure 9.

\section{Members of the Isismurra Formation}

Discussion in this section is confined to those members in the northern part of the Rouchel block, adjacent to the Waverley Fault. Details of the Native Dog Member, Curra Keith and Oakfields Tongues, and Martins Creek Ignimbrite Member are given by Roberts and Oversby (1974) and Roberts et al. (1991). The Curra Keith Tongue emerges from the Native Dog Member at Dangarfield, between Aberdeen and Upper Rouchel, and extends northwards to the Waverley Fault (Caldwell 1985) and 
eastwards to the vicinity of Mt Scrumlo (0329650E 6439750N Rouchel Brook 1:25 000 sheet). It is underlain by the Ayr Conglomerate and overlain by a thin succession of sedimentary rocks and the Oakfields Tongue. Roberts et al. (1995a) used the SHRIMP SL13 age for the Curra Keith Tongue to define an age of $342.1 \pm 3.2 \mathrm{Ma}(2 \sigma)$ for the Tournaisian-Visean Stage boundary. Given doubts concerning the reliability of the SL13 standard and a difference of about $-2 \%$ when compared with ages derived from the AS3 standard (Black et al. 2003a), the Curra Keith Tongue was redated using the FC1 and AS3 standards. The weighted mean of 24 analyses gives an age of $349.6 \pm 1.7 \mathrm{Ma}$ (sample 542-1, Figure 13c). This age is approximately $2 \%$ older than that determined using the SL13 standard. It provides a basis for the Tournaisian-Visean boundary in Figure 10. Up to three red ignimbrites are commonly present above the Native Dog Member and Curra Keith and Oakfields Tongues throughout the Rouchel block. In most cases, they are unwelded and contain white phenocrysts of feldspar, quartz, and a shard-rich, glassy to partly devitrified groundmass. Those in the region adjacent to Upper Rouchel can be distinguished on the basis of petrological criteria (Roberts \& Oversby 1974) and were identified as ignimbrites $a, b$ and $c$. Elsewhere, the red ignimbrites are unwelded and indistinguishable from one another lithologically. They were not assigned letter symbols by Roberts et al. (1991).

At the northern boundary of the Rouchel block, fault blocks west of Merric (0314820E 6466800N Waverley 1:25 000 sheet) and the Isis River contain four separate bodies of red ignimbrite. Two are in sequence with the Oakfields and Curra Keith Tongues, but the other two lack stratigraphic control because of faulting. The red, unwelded ignimbrite overlying the Curra Keith and Oakfields Tongues $0.5 \mathrm{~km}$ west of Merric, termed ignimbrite A by Caldwell (1985), has a normal magnetic polarity (Geeve 2000). The same unit is tentatively identified in the adjacent fault block south of the Gundy Fault. The two ignimbrites lacking lower stratigraphic control in blocks west and northwest of Merric were termed ignimbrites B and D (Caldwell 1985). These units, which are slightly different lithologically from ignimbrite A (Appendix 1), are essentially identical and have SHRIMP AS3 ages of $346.3 \pm 2.7 \mathrm{Ma}$. (Sample 532-1A, Figure 13d) and $346.8 \pm 2.1 \mathrm{Ma}$ (sample 527-24, Figure 13e). Ignimbrite D has a reversed polarity (Geeve 2000). The most likely interpretation is that there are two red ignimbrites within the Isismurra Formation between the Isis River and the Waverley Fault: unnamed ignimbrite $\mathrm{A}$ and unnamed ignimbrite $\mathrm{B} / \mathrm{D}$.

In the vicinity of Gundy Mountain (0317900E $6461100 \mathrm{~N}$ Waverley 1:25000 sheet), a red unnamed ignimbrite underlies an intercalation of the Woolooma Formation (Saxton 1984). An occurrence of the trilobite Linguaphillipsia elongata elongata (Mitchell) in the Woolooma Formation less than $2 \mathrm{~km}$ to the south (Saxton 1984) indicates that the Woolooma Formation in this region is younger than that at Upper Rouchel (Appendix 1). The red unnamed ignimbrite between the Isis River and Belltrees could, therefore, be equivalent to ingimbrite $a$ at Upper Rouchel and ignimbrite A of Caldwell (1985). If correct, the reversed polarity of ignimbrite $\mathrm{D}$ may indicate that ignimbrite $\mathrm{B} / \mathrm{D}$ is equivalent to ignimbrite $c$ at Upper Rouchel (Geeve 2000).

\section{SEAHAM FORMATION}

The Namurian to Westphalian Seaham Formation (Sussmilch \& David 1920; Roberts et al. 1991) crops out south of the Waverley Fault in a belt along or close to the Hunter Thrust. In the northern part of the Rouchel block, a granitic, boulder to cobble conglomerate up to $300 \mathrm{~m}$ thick marks a major disconformity with the underlying Isismurra Formation. The conglomerate extends for $\sim 15 \mathrm{~km}$ from Merric (Figure 9, section 524527), immediately south of the Waverley Fault, to the southern margin of Black Mountain; it is normally poorly exposed but readily identifiable from the abundant scree of granitic clasts. Sedimentary rocks overlying the conglomerate include pebble to cobble conglomerate, grey, beige or multicoloured volcanolithc sandstone, siltstone and minor diamictite. The succession displays considerable lateral diversity (Appendix 1).

Members of the Seaham Formation

The Elmswood Ignimbrite Member (Plate 1; Appendix 1) crops out around the southern to southeastern flank of Black Mountain and on the eastern slope of Lagoon Mountain (0310500E6465400N Parkville 1:25 000 sheet). It appears to be located at about the same stratigraphic level as a green, ash-rich siltstone (locality 528-2 0211600E 6465590N Waverley 1:25 000 sheet). The ignimbrite has a SHRIMP AS3 age of $326.4 \pm 2.6$ Ma (sample 538-40, Figure 13f). The younger Kewell Creek Volcanic Member (Appendix 1) (Manser 1967) is a thick, widespread unit extending from south of the Waverley Fault and Wingen to Muswellbrook (Plate 1). It is a composite unit of rhyodacitic to dacitic ash-flow and ash-fall ignimbrites, volcanic agglomerate and epiclastic conglomerate, sandstone and multicoloured, ash-rich siltstone (Appendix 1). A sample from the base of the member has a SHRIMP AS3 age of $320.5 \pm 2.8 \mathrm{Ma}$ (sample 284-2, Figure 14a). The sedimentary sequence above the Kewell Creek Volcanic Member consists predominantly of grey to beige volcanolithic sandstone, pebble conglomerate and minor crystal tuff and siltstone. Ignimbrites from within the succession are known from two outcrops. The most substantial, the Well Gully Ignimbrite Member (Appendix 1), is present on the western slope of Colonel Mountain, $220 \mathrm{~m}$ above the Kewell Creek Volcanic Member. It has a SHRIMP AS3 age of $305.7 \pm 2.7 \mathrm{Ma}$ (sample 556-5, Figure 14b). The second ignimbrite, from a comparable stratigraphic position on the northwestern slope of Black Mountain (locality 544-20, 0302470E 6464604N Parkville 1:25 000 sheet) has a different composition (Appendix 1).

The boundary between the Seaham and Temi Formations in some places is difficult to define because the Temi Formation contains detritus derived from the erosion of Carboniferous strata. Sandstones, the most common lithology in the Temi Formation, are distinguished from those in the Seaham Formation in containing rounded to subrounded, well-sorted grains cemented by chlorite or chalcedony. 


\section{DISCUSSION}

\section{Comparison of the Werrie and Rouchel blocks}

Despite having an overall sequential and lithological similarity, there are differences in the timing of episodes of uplift, erosion, deposition and volcanism in Carboniferous successions of the Werrie and Rouchel blocks. A time-space chart of the region (Figure 10) constructed by projecting limits of outcrop on to a line extending from the northern margin the Castle Mountain Dome, near Quirindi, to the Waverley Fault and thence southwards to the southern end of Bells Mountain, east of Muswellbrook, provides a simplified picture of the relationships between the two blocks. Time control is by means of SHRIMP AS3 dates, two SHRIMP SL13 dates increased in age by $+2 \%$ following Black et al. (2003a), and brachiopod zones from marine intercalations in the Merlewood and Isismurra Formations.

Depositional facies in the two blocks suggest that the southern Werrie and Rouchel blocks were located in different depositional regions in the forearc basin. Deep-marine mudstones with sporadic conglomerate lenses (Manser 1968) (Goonoo Goonoo Formation), which shallow upwards and are succeeded by fluvial volcanolithic sandstone and the Isismede Ignimbrite Member (352 Ma) (Merlewood Formation), typify the southern Werrie block in the Tournaisian. In contrast, coeval successions in the Rouchel block were deposited in shallow shelfal to fluvial environments. Early Tournaisian volcanolithic sandstone, conglomerate, tuffs, minor pyroclastics and siltstone (Kingsfield Formation) were followed in the middle to late Tournaisian by a transgressive sequence of marine sandstone, oolitic limestone (Brushy Hill Limestone Member) and shelly mudstone, minor lithic sandstone and limestone (Dangarfield Formation) (Roberts \& Oversby 1974; Roberts et al. 1991). Fossiliferous shallow-marine mudstone and limestone existed well towards the east during the midTournaisian (Saxton 1984; Roberts et al. 1991). Renewed volcanism in the late Tournaisian led to deposition of fluvial to shallow-marine sandstone and siltstone (Waverley Formation) on the northern, eastern and southern flanks of the Dangarfield Formation.

Visean successions of both blocks are dominated by fluvial, volcanolithic sandstone, conglomerate and ignimbrite. In the southern Werrie block, there were two minor, early Visean, marine incursions (Orthotetes australis Zone and Inflatia elegans Subzone) into the fluvial facies (Merlewood Formation). Two episodes of volcanism produced the Burnewang Ignimbrite Member (343 Ma) and the Wheelihans Gap Ignimbrite Member and unnamed ignimbrite M4 (both ca $327 \mathrm{Ma}$ ). In the Rouchel block, there was uplift and erosion in the latest Tournaisian or earliest Visean, followed by deposition of piedmont conglomerate (Ayr Conglomerate Member) at the base of a thick volcaniclastic and ignimbritic succession (Isismurra Formation) (Roberts \& Oversby 1974). Volcanism from a centre located southwest of the modern location of Muswellbrook (Buck 1984) gave rise to extensive ignimbrites (Native Dog Ignimbrite Member, Curra Keith and Oakfields Tongues) (Roberts \& Oversby 1974). An early Visean marine transgression across a large part of the Rouchel block produced a substantial intercalation of shallow-marine sediments (Woolooma Formation). Shelly faunas of the Inflatia elegans Subzone predominate in the western part of the block, and the Orthotetes australis Zone and Inflatia elegans Subzone (Roberts \& Oversby 1974; Roberts 1975) are present farther east. These are coeval with the marine incursions into the Merlewood Formation in the southern Werrie block. Regression of the Woolooma Formation was followed by further volcanism producing unnamed red ignimbrites and volcanolithic sediments (Isismurra Formation) (Roberts \& Oversby 1974). In the region between the Isis River and Belltrees, marine sediments could be younger than those in the vicinity of Upper Rouchel, as they contain a trilobite typical of the younger Linoprotonia tenuirugosa Zubzone of the Delepinea aspinosa Zone. Later in the Visean, the distal part of an andesitic ignimbrite (Martins Creek Member), emanating from a source southeast of the Rouchel block (Roberts et al. 1991), was deposited in the southeastern part of the block.

Late Carboniferous continental, volcanogenic and glacigenic deposition commenced earlier in the Rouchel than in the Werrie block, with the basal part of the succession in the Rouchel block (Seaham Formation) possibly being diachronous with the uppermost preserved part of the Merlewood Formation of the Werrie block. This is suggested by SHRIMP AS3 ages of $326.4 \pm 2.9 \mathrm{Ma}$ for the Elmswood Ignimbrite Member, from about $700 \mathrm{~m}$ above the base of the Seaham Formation, and ca $327 \mathrm{Ma}$ for the Wheelihans Gap Ignimbrite Member from the uppermost part of the Merlewood Formation. The Werrie block was uplifted and eroded during the earliest Namurian, following which there was the deposition of volcanoclastic and glacigene sediments (Currabubula Formation). In the southern part of the block, deposition continued until at least $310 \mathrm{Ma}$, the age of the youngest dated ignimbrite members in the Back Creek Anticline. Volcanic successions typically contain many individual ignimbrites and lavas within a number of local successions, suggesting derivation from a number of smaller volcanic centres. Stratigraphic relationships between these local successions are reasonably well known, but those of the Karralee Ignimbrite Member and lavas in the fault block between Spring Creek and the western flank of Mt Pleasant (Figure 6) have not been determined. This succession could be either older than the adjacent sequence immediately north of Murrurundi, or younger than that in the core of the Back Creek Anticline. The Seaham Formation in the Rouchel block contains three mapped ignimbrites. The Elmswood Ignimbrite Member may be about the same age as the Mirannie Ignimbrite Member (SHRIMP SL13 321.3 + 4.4. Ma: Roberts et al. 1995b) from the lower part of the Seaham Formation in the southern parts of the Rouchel and Gresford blocks. The extensive Kewell Creek Volcanic Member (SHRIMP AS3 $320.5 \pm 2.9 \mathrm{Ma}$ ) (Plate 1 ) has no equivalent in the Werrie block but is similar to the Birken Head Volcanic Member of the Willuri Formation in the CarrollNandewar region of the Tamworth Belt in that it contains ignimbrites and epiclastic, rhyodacitic conglomerate, sandstone and siltstone (Roberts et al. 2004). 
The Well Gully Rhyodacite Member (SHRIMP AS3 $305.7 \pm 2.7 \mathrm{Ma}$ ), the youngest member of the Seaham Formation in the Rouchel block, is close in age to the Matthews Gap Dacitic Tuff Member (Brakel 1972) (IDTIMS $309 \pm 3$ Ma: Gulson et al. 1990), the uppermost member of the Pokolbin Hills Volcanics at Mt View, Pokolbin. Sediments identified as Seaham Formation overlie the Pokolbin Hills Volcanics at Mt View (Brakel 1972) and may be of a similar or younger age to the uppermost part of the Seaham Formation in the Rouchel block.

\section{Block boundaries}

The boundary between the Werrie and Rouchel blocks is defined by the Waverley Fault northeast of Staircase Mountain (Plate 1) and obscured to the southwest by the overlying Permian Temi Formation and Werrie Basalt (Plate 1). The Waverley Fault, which has the same orientation as a northeasterly group of faults in the Rouchel block, is interpreted as a thrust, although it also possesses evidence of both sinistral and dextral strike-skip movement based on the orientation of slickenlines, slickenfibres on shear joints, and displaced markers such as cobbles or bedding (R. Offler unpubl. data). Whether movement on the Waverley Fault is of sufficient magnitude to account for the differences between the blocks, outlined above, is unknown. Major faults in the southern Tamworth Belt delineating the boundaries between the Rouchel, Gresford and Myall blocks include the meridional to north-northeasttrending, steeply dipping Karrakurra and Williams River Faults. These appear to have been active during the Carboniferous in controlling rates of subsidence and depositional patterns, to the extent that different stratigraphic successions developed in the Rouchel, Gresford and Myall blocks (Roberts \& Engel 1987).

The nature of the block boundaries became more problematic after palaeomagnetic studies indicated that blocks in the southern Tamworth Belt had been rotated relative to the Australian craton; the Hastings block $230^{\circ}$ counterclockwise or $130^{\circ}$ clockwise (Schmidt et al. 1994), the Rouchel and Gresford blocks $80^{\circ}$ counterclockwise, and the western Myall block $120^{\circ}$ counterclockwise (Geeve et al. 2002). These studies were referenced to the SLP Apparent Polar Wander Path (Schmidt et al. 1990). Reassessment of data from Opdyke et al. (2000) by McElhinny et al. (2003), using a revised version of the SLP Apparent Polar Wander Path based solely on cratonic pole positions assessed by a Quality Index (Van der Voo 1990), determined that the Rocky Creek block was located well east of the cratonic polar wander path, whereas the Werrie block was closer to, but not on, the polar wander path. Both blocks were considered to be allochthonous.

In separate studies, Klootwijk $(2002,2003)$ used pole paths based on mean pole positions for individual volcanic members of the Currabubula Formation in the Werrie block and the Clifden Formation, Rocky Creek Conglomerate, and Lark Hill Formation in the Rocky Creek block to establish a Late Palaeozoic pole path for the northwestern Tamworth Belt. This was compared with a preliminary pole path from the
Rouchel and western Gresford blocks (Klootwijk 2003). A comparison of these paths with the KG Polar Wander Path (Klootwijk \& Giddings 1988; Klootwijk 1996) led him to conclude that there had been no rotation within northwestern and southwestern parts of the belt. However, the KG pole path includes "various poles rejected in the SLP definition which have been re-interpreted as Early Carboniferous overprints, and a considerable number of Middle and Late Palaeozoic pole positions obtained in the course of AGSO studies on the Tasman Orogenic zone (TOS) and cratonic basins' (Klootwijk 1996 p. 11). A major problem for the KG pole path is the need to interpret the Snowy River Volcanics (SRV) pole, which passes a fold test, as a mid-Late Carboniferous overprint. In addition, unlike the long-accepted and independently tested SLP polar wander path, recently updated by McElhinny et al. (2003), the KG pole path has been constructed in such a way to accommodate any block rotations by making the APWP more complex. Such an approach is to deny the existence of rotated blocks or terranes. None of the KG data has been scrutinised by a Quality Index such as that used by Van der Voo (1990) or the classification of $\mathrm{Li}$ and Powell (1993), as applied by Geeve et al. (2002). Schmidt and McElhinny (2003 p. 131), furthermore, maintained that 'Klootwijk's (2002) analysis of magnetisation components, his application of the fold test and his derivation of pole positions are flawed and cannot be used for tectonic studies in any way'. These comments, together with a warning that all Carboniferous to Permian palaeomagnetic results from the Tamworth Belt are not applicable to the Australian craton (McElhinny et al. 2003) are sufficient to cast doubt upon the validity of Klootwijk's (2003) conclusion that the blocks of the Tamworth Belt are autochthonous.

\section{Disconformities}

McPhie's (1987) work in the region north of the Castle Mountain Dome recognised the importance of disconformities to the internal architecture of the Currabubula Formation. Palaeovalleys were identified by the truncation of major ignimbrites or conglomerate infills. This style of erosion extends into the southern part of the Werrie block and affects the Currabubula and Woodton Formations. At least three major hiatuses are recognisable: (i) at the base of the Currabubula Formation in the early Namurian; (ii) beneath the Woodton Formation from the Stephanian to late Asselian; and (iii) beneath parts of the Temi Formation or Werrie Basalt during the early Sakmarian.

In the upper part of the Merlewood Formation, the discontinuous nature of the Wheelihans Gap Ignimbrite Member and unnamed ignimbrite M4 is clearly controlled by the disconformity at the base of the Seaham Formation. Discontinuous outcrops of the Isismede and Burnewang Ignimbrite Members could, however, be due to either penecontemporaneous erosion or poor outcrop. The majority of ignimbrites in the Currabubula Formation in the Wallabadah-Waverley region have undergone erosion. Major disconformities illustrated in Figure 10 confirm a previous interpretation (Davies 1988) of disconformities in the region encompassing the 
Quipolly Dome, Castle Mountain Dome and Chilcotts Creek. The Cana Creek Tuff is cut by a possible channel $2 \mathrm{~km}$ west of Wallabadah, extends a further $6 \mathrm{~km}$ southwards, and reappears only as remnants and eroded debris between Big Double Mountain and Chilcotts Creek homestead. South of the Liverpool Range, unnamed ignimbrites C4 and C3 appear to be erosional remnants, and a gap in outcrops of the Murrurundi and Cohens Gully Ignimbrite Members north of Murrurundi (Figure 6) may be indicative of channel erosion. The disconformity between the earliest Permian Woodton and the Late Carboniferous Currabubula Formations was responsible for the removal of the White Rocks Ignimbrite Member $4 \mathrm{~km}$ west of Wallabadah, and erosion of ignimbrites in the Back Creek Anticline. Further erosion in the latest Asselian to earliest Sakmarian removed the Woodton Formation from the region between the Liverpool Range and Greers Mountain and eroded the Willawarra Rhyodacite Member prior to deposition of the Temi Formation. The latter unit was also subjected to erosion before extrusion of the Werrie Basalt.

Channel-fill conglomerates and discontinuous ignimbrites are atypical of the Isismurra and Seaham Formations in the Rouchel block. An early Visean disconformity between the Isismurra Formation and the Dangarfield and Waverley Formations (Roberts \& Oversby 1974) in the Rouchel block has no apparent counterpart in the southern Werrie block. The Ayr Conglomerate Member at the base of the Isismurra Formation is a piedmont deposit (Roberts \& Oversby 1974), and an extensive, but poorly exposed, conglomerate at the base of the Seaham Formation may have a similar origin. The duration of the disconformity between the Seaham and Isismurra Formations (Roberts et al. 1995a, b) has been further clarified by additional SHRIMP dates (Figure 10).

\section{Late Carboniferous - Early Permian evolution of the southern New England Orogen}

Two recent models for the Late Palaeozoic evolution of the southern New England Orogen (Caprarelli \& Leitch 1998, 2001; Jenkins et al. 2002) involve alternative mechanisms, namely slab breakoff and rollback, respectively, to explain the timing of easterly migration of the subduction zone, generation of granitic suites, largescale volcanism and deformation. Both proposed the cessation of Late Carboniferous volcanism at around $310 \mathrm{Ma}$, prior to the commencement of either slab breakoff or rollback. Intrusion of Hillgrove Suite granitoids into the Tablelands Complex at 302 Ma (Collins et al. 1993; Kent 1994) was interpreted by Caprarelli and Leitch (1998) as a response to the melting of sediments by upwelling of asthenosphere, following slab breakoff; intrusion took place in a compressive environment. However, Jenkins et al. (2002) suggested that rollback by $300 \mathrm{Ma}$ had caused magmatism to move eastward into the subduction complex, resulting in generation of the Hillgrove Suite in an extensional environment.

SHRIMP ages for Carboniferous ignimbrites and tuffs in the Seaham Formation in the Rouchel block and DM Tangorin DDH1 (Claoué-Long \& Korsch 2003) in the
Gresford block to the southeast indicate that arc-type volcanism persisted beyond $310 \mathrm{Ma}$. The SHRIMP data include the Well Gully Ignimbrite Member (SHRIMP AS3 $305.7 \pm 2.7 \mathrm{Ma}$ ) and Mt Durham Tuff Members (SHRIMP SL13 306.5 $\pm 2.1 \mathrm{Ma}$ ) (Claoué-Long \& Korsch 2003). Tuffs, interbedded with conglomerates containing intermediate and basaltic clasts, in the younger Tamby Creek Formation in DM Tangorin DDH1 have SHRIMP SL13 ages ranging from 304 to $300 \mathrm{Ma}$ (Claoué-Long \& Korsch 2003). The tuffs were described as intermediate to felsic in origin (Stevenson 2003) in DM Tangorin DDH1 and of intermediate origin in DM Cranky Corner DDH3 (Stevenson 2003). A recent reconnaissance geochemical study of tuffs in the Tamby Creek Formation from DM Tangorin DDH1 indicate that they are dacitic to rhyodacitic in composition and of possible arc origin. Basaltic andesite to andesitic clasts in a conglomerate from the Tamby Creek Formation, however, have compositions that are transitional between oceanic and continental arc basalts (R. Offler unpubl. data). Basaltic andesite clasts having the same geochemical affinity are present in the Currabubula Formation, an equivalent of the Seaham Formation, at Camerons Gorge on the Pages River (locality 565-9, 0310428E 6469108 Waverley 1:25 000) (R. Offler unpubl. data). These occurrences do not support the suggestion of Claoué-Long and Korsch (2003) that an extensional event initiating rift basins in the southern New England Orogen took place prior to the Early Permian.

Deposition of Permian (Asselian) lacustrine sediments and extrusion of rhyodacitic lavas and ignimbrites (SHRIMP AS3 age of $290.6 \pm 2.8 \mathrm{Ma}$ ) of the Woodton Formation in the Werrie block took place at about the same time as that of rhyodacitic lava flows in the Carroll-Nandewar region (297-287 Ma) (Roberts et al. 2004) and subsidence and marine deposition (Lyonia bourkei Zone) in the Hastings block and Barnard and Nambucca Basins in the Tablelands Complex (Briggs 1998; Caprarelli \& Leitch 1998). Some geochemical data are available from the rhyodacites in the Woodton Formation at the western margin of the Tamworth Belt. These have a within-plate signature (R. Offler unpubl. data) confirming the rift setting that is believed to have existed at this time (Leitch 1993). Rifting in the southern New England Orogen, therefore, appears to have commenced in the Tablelands Complex between the Stephanian and Asselian. The age of the of the Woodton Formation provides a limit on the maximum age of the disconformably overlying Temi Formation and Werrie Basalt, both of which are widespread throughout the Werrie block and overlie the western extremity of the Waverley Fault and Seaham Formation in the northwestern part of the Rouchel block. Sparse marine fossils from these units, including the upper part of the Temi Formation at Willow Tree (Runnegar 1970) and a sandstone in the Werrie Basalt on Loders Mountain (Lowe 1971), are considered to be equivalent to the Sakmarian Strophalosia concentrica Zone (Briggs 1998).

Deformation of the Tamworth Belt has traditionally been related to the Late Permian Hunter-Bowen Orogeny. Scheibner and Veevers (2000) postulated a Late Carboniferous (320-300 Ma) deformation, dated by metamorphic events in the subduction complex to the 
east, which involved the Tamworth Belt being thrust over the volcanic arc and creating and filling a now obscured foreland basin to the west. For this to be the case, strata below the Gunnedah Basin in deep seismicreflection profile BMR91.G01 (Glen \& Brown 1993; Korsch et al. 1997) would have to reinterpreted as foreland basin fill rather than Lachlan Orogen. Field evidence for Early Permian or pre-Permian compressional deformation and faulting in the southern Tamworth Belt is available from east of Wingen and Barrington Tops. The Waverley Fault, east of Wingen, stops abruptly $2.4 \mathrm{~km}$ south of the entrance to the Pages River Gorge (GR 0309428E 6467602N Parkville 1:25000 sheet). Southwest of the termination, the sedimentary succession in the Temi Formation is undisturbed by faulting and overlies the Waverley Fault (Plate 1). The Kewell Creek Volcanic Member (AS3 $320.5 \pm 2.9 \mathrm{Ma}$ ) is overlain by the Temi Formation at Staircase Mountain, and at Colonel Mountain by sedimentary rocks and the Well Gully Ignimbrite Member (AS3 $305.7 \pm 2.7 \mathrm{Ma}$ ). These relationships suggest that the earliest movement on the Waverley Fault took place later than $306 \mathrm{Ma}$, the age of the Westphalian-Stephanian boundary, and prior to the Sakmarian.

In the Barrington Tops region, folded and faulted Devonian, Early Carboniferous and Early Permian successions have been intruded and contact metamorphosed by the I-type Barrington Tops Granodiorite (Bradshaw 1982; Cross 1983; Roberts et al. 1991). The precise age of the Barrington Tops Granodiorite is difficult to determine. Three $\mathrm{K}$ - Ar ages with an average age of $266 \mathrm{Ma}$ (Roberts et al. 1991) are close to the Rb-Sr age of $262 \mathrm{Ma}$ (Hensel et al. 1985). An IDTIMS analysis of five crystals from sample MR-1 produced a weighted mean ${ }^{206} \mathrm{~Pb} /{ }^{238} \mathrm{U}$ age of $265 \pm 8 \mathrm{Ma}$ or, with the exclusion of one sample, an age of $269 \pm 2$ Ma (R. Offler \& W. Collins unpubl. data). IDTIMS analyses (Kimbrough et al. 1993) produced discordant results, the ${ }^{206} \mathrm{~Pb} /{ }^{238} \mathrm{U}$ age grouping around $252 \mathrm{Ma}$ and the ${ }^{207} \mathrm{~Pb} /{ }^{238} \mathrm{U}$ age around $281 \mathrm{Ma}$. Kimbrough et al. (1993) interpreted the discordance to be the result of $\mathrm{Pb}$ loss rather than an inherited component. SHRIMP analysis of material from sample MR-1 of R. Offler and W. Collins (unpubl. data) gives a weighted mean ${ }^{206} \mathrm{~Pb} /{ }^{238} \mathrm{U}$ age of $280 \pm 5 \mathrm{Ma}$. Given that there appears to be agreement between the ${ }^{207} \mathrm{~Pb} /{ }^{238} \mathrm{U}$ IDTIMS age of $281 \mathrm{Ma}$ of Kimbrough et al. (1993) and the ${ }^{206} \mathrm{~Pb} /{ }^{238} \mathrm{U}$ SHRIMP age of $280 \pm 5 \mathrm{Ma}$, and that the ${ }^{207} \mathrm{~Pb} /{ }^{238} \mathrm{U}$ component of the IDTIMS analysis of sample MR-1 was poorly constrained, we favour an age of around 280 Ma for the Barrington Tops Granodiorite; this is Artinskian in terms of the time-scale of Menning (2001). Both the folding and faulting of Devonian, Carboniferous and Lower Permian sedimentary rocks in the Barrington Tops region and the existence of the Waverley Fault prior to the Sakmarian point towards orogenic events in the Tamworth Belt which were earlier than the Late Permian Hunter-Bowen Orogeny.

\section{CONCLUSIONS}

(1) A stratigraphic and environmental comparison of successions on either side of the Waverley Fault illustrates that both formations and members are restricted to either the Werrie or Rouchel blocks of the Tamworth Belt. These differences are unlikely to be explained by regional variation in depositional environments or faulting and indicate that the two blocks were not immediately juxtaposed during the greater part of the Carboniferous Period. Palaeopole positions for the two blocks (Geeve et al. 2002; McElhinny et al. 2003) provide confirmation that the two blocks are allochthonous, although there is a dissenting view in the case of the Werrie block (Klootwijk 2003).

(2) Uplift and erosion of the blocks were asynchronous, taking place in the latest Tournaisian-earliest Visean and latest Visean in the Rouchel block and early Namurian and latest Carboniferous or earliest Permian in the southern Werrie block. Deposition of formations of similar facies, for example the Merlewood and Isismurra Formations and Currabubula and Seaham Formations, also commenced at different times (Figure 10). Channel erosion, typical of the Currabubula Formation (McPhie 1987), is not a significant factor in the Seaham Formation in the Rouchel block.

(3) The Woodton Formation is earliest Permian (Asselian) rather than Carboniferous in age and approximately equivalent to earliest Permian marine successions in the northern Hastings block, Nambucca block and Barnard Basin, all of which contain the Asselian Lyonia bourkei Zone (Briggs 1998). The age of the Brogans Rhyodacite Member indicates that the overlying Temi Formation is younger than $290 \mathrm{Ma}$.

(4) Possible arc-type dacitic to rhyodacitic tuffs, and oceanic to continental arc basaltic andesite to andesite clasts in the Tamby Creek Formation, suggest that rifting in the southern New England Orogen did not occur until the Early Permian.

(5) Deformation affected parts of the Rouchel and Gresford blocks prior to intrusion of the Barrington Tops Granodiorite ( $c a 280 \mathrm{Ma}$ ) and the major PermoTriassic Hunter-Bowen Orogeny.

\section{ACKNOWLEDGEMENTS}

This research was funded by Large ARC Grant A39917100. David Keith, University of New England, is thanked for the loan of thin-sections and access to palaeobotanical specimens. Rodney Gould kindly identified the palaeobotanical specimens. Mark Dawson and Ken McDonald, New South Wales Mineral Resources, Armidale, provided access to compilations of geological maps and conversion of grid data. Bill Collins is thanked for the use of unpublished data and Phil Schmidt for advice on palaeomagnetics. Irene Wainwright carried out the XRF analyses. Mineral Resources New South Wales, particularly John Watkins, is thanked for supporting the cost of publication of Plate 1 . Constructive comments on the manuscript by Dick Glen, Barrie McKelvey and Albert Brakel are greatly appreciated. 


\section{REFERENCES}

Black L. P., Kamo S. L., Williams I. S., Mundil R., Davis. D. W. KoRSCH R. J. \& FoudOULIS C. 2003a. The application of SHRIMP to Phanerozoic geochronology: a critical appraisal of four zircon standards. Chemical Geology 200, 171-188.

Black L. P., Kamo S. L., Allen C. M., Aleinikoff J. N., Davis. D. W., KoRsCH R. J. \& Foudoulis C. 2003b. TEMORA 1: a new zircon standard for Phanerozoic U-Pb geochronology. Chemical Geology 200, $155-170$.

BRADSHAW J. 1982. Geology of the Omadale Brook district. BSc (Hons) thesis, University of New South Wales, Sydney (unpubl.).

BRAKEL A. T. 1972. The geology of the Mt. View Range district, Pokolbin, NSW. Journal and Proceedings of the Royal Society of New South Wales 105, 61-70.

BRIGGS D. J. C. 1998. Permian Productidina and Strophalosiidina from the Sydney-Bowen Basin and New England Orogen: systematics and biostratigraphic significance. Association of Australasian Palaeontologists Memoir 19.

BRownE W. R. 1926. The geology of the Gosforth district. Journal and Proceedings of the Royal Society of New South Wales 60, 213-277.

BucK M. 1984. Muswellbrook volcanic centre-a source for the Carboniferous ignimbrites in the Upper Hunter Valley. Geological Society of Australia Abstracts 12, 82-83.

CALDWELL C. 1985. The geology of the Waverley district. BSc (Hons) thesis, University of New South Wales, Sydney (unpubl.).

CAPRARELLI G. \& LeITCH E. C. 1998. Magmatic changes during the stabilisation of a cordilleran fold belt: the Late Carboniferous Triassic igneous history of eastern New South Wales, Australia. Lithos 45, 413-430.

CAPRARelli G. \& Leitch E. C. 2001. Geochemical evidence from Lower Permian volcanic rocks of northeast New South Wales for asthenospheric upwelling following slab breakoff. Australian Journal of Earth Sciences 48, 151-166.

CAREY S. W. 1934. The geological structure of the Werrie Basin. Proceedings of the Linnean Society of New South Wales 59, 351374.

CAREY S. W. 1937. The Carboniferous sequence in the Werrie Basin. Proceedings of the Linnean Society of New South Wales 62, 341376.

CHERRY D. P. 1987. A Late Palaeozoic sequence at Castle Mountain, southeast of Quirindi, NSW. BSc (Hons) thesis, University of New England, Armidale (unpubl.).

Cladoú́-Long J. C. \& KoRSCH R. J. 2003. Numerical time measurement in the DM Tangorin DDH1 drillcore. In: Facer R. A. \& Foster C. B. eds. Geology of the Cranky Corner Basin, pp. 179-205. New South Wales Department of Mineral Resources, Coal and Petroleum Bulletin 4.

ColLins W. J. 1991. A reassessment of the 'Hunter-Bowen Orogeny': tectonic implications for the southern New England Fold Belt. Australian Journal of Earth Sciences 38, 409-423.

Collins W. J., OfFler R., FARRell T. R. \& LANDENBERger B. 1993. A revised Late Palaeozoic-Early Mesozoic tectonic history for the southern New England Fold Belt. In: Flood P. G. \& Aitchison J. C. eds. New England Orogen eastern Australia, pp. 69-84. Department of Geology \& Geophysics, University of New England, Armidale.

CROOK K. A. W. 1961. Stratigraphy of the Parry Group (Upper Devonian-Lower Carboniferous), Tamworth-Nundle district, NSW. Journal and Proceedings of the Royal Society of New South Wales 94, 189-207.

Cross K. C. 1983. The Pigna Barney Ophiolitic Complex and associated basaltic rocks, northeastern New South Wales. PhD thesis, University of New England, Armidale (unpubl.).

DAVIES J. S. 1988. The palaeogeography and sedimentation of a Late Carboniferous volcaniclastic sequence in the WallabadahWoodton area, northeastern New South Wales. BSc (Hons) thesis, University of New England, Armidale (unpubl.).

DAwson T. M. 1988. The stratigraphy and sedimentation of a Late Palaeozoic sequence in the Emblem and Quipolly Dome areas, northeast of Quirindi, New South Wales. BSc (Hons) thesis, University of New England, Armidale (unpubl.).

ENGel B. A. 1966. Explanatory Notes on the Newcastle 1:250000 Geological Sheet SI 56-2. Geological Survey of New South Wales, Sydney.
ENGEL B. A. \& MoRris N. 1990. The biostratigraphic potential of Carboniferous trilobites from eastern Australia. Courier Forschungsinstitut Senkenberg 130, 189-198.

GeEve R. J. 2000. Palaeomagnetism in the southern Tamworth Belt. $\mathrm{PhD}$ thesis, University of New South Wales, Sydney (unpubl.).

GEEvE R. J., SCHMIDT P. W. \& ROBERTS J. 2002. Paleomagnetic results indicate pre-Permian counter-clockwise rotation of the southern Tamworth Belt, southern New England Orogen, Australia. Journal of Geophysical Research 107, B9, 2196, 1-16.

GLEN R. A. \& BROWN R. E. 1993. A transect through a forearc basin preliminary results from a transect across the Tamworth Belt at Manilla, NSW. In: Flood P. G. \& Aitchison J. C. eds. New England Orogen, eastern Australia, pp. 105-111. Department of Geology \& Geophysics, University of New England, Armidale.

Gulson B. J., DiesSel C. F. K., MASON D. R. \& KROGH T. E. 1990. High precision radiometric ages from the northern Sydney Basin and their implication for the Permian time interval and sedimentation rates. Australian Journal of Earth Sciences 37, 459-469.

Hensel H. D., McCulloch M. T. \& Chappell B. W. 1985. The New England Batholith: constraints on its derivation from $\mathrm{Nd}$ and $\mathrm{Sr}$ isotopic studies of granites and country rocks. Geochimica et Cosmochimica Acta 49, 369-384.

HoCKLEY J. J. 1966. A synthesis of the stratigraphy and petrography of some Carboniferous rocks from the Werrie Basin, New South Wales. BSc (Hons) thesis, University of New England, Armidale (unpubl.).

Jenkins R. B., LANDEnBerger B. \& Collins W. J. 2002. Late Palaeozoic retreating and advancing subduction boundary in the New England Fold Belt, New South Wales. Australian Journal of Earth Sciences 49, 467-489.

KELK P. 1986. The stratigraphy and sedimentation of a Late Carboniferous to Early Permian terrestrial pyroclasticepiclastic sequence $80 \mathrm{~km}$ south of Tamworth, New South Wales. BSc (Hons) thesis, University of New England, Armidale (unpubl.).

Kent A. J. R. 1994. Geochronology and geochemistry of Palaeozoic intrusive rocks of the Rockvale region, southern New England Orogen, New South Wales. Australian Journal of Earth Sciences 41, 365-379.

Kimbrough D. L., Cross K. C. \& Korsch R. J. 1993. U-Pb isotopic ages for zircons from the Pola Fogal and Nundle granite suites, southern New England Orogen. In: Flood P. G. \& Aitchison J. C. eds. New England Orogen, eastern Australia, pp. 403-412. Department of Geology \& Geophysics, University of New England, Armidale.

KLOOTWIJK C. T. 1996. Phanerozoic configuration of greater Australia: evolution of the North West Shelf. Part 2. palaeomagnetic and geologic constraints on reconstructions. Australian Geological Survey Organisation Record 1996/52.

KLOOTWIJK C. T. 2002. Carboniferous palaeomagnetism of the Rocky Creek Block, northern Tamworth Belt, and the New England pole path. Australian Journal of Earth Sciences 49, 375-405.

KLOOTwIJK C. T. 2003. Carboniferous palaeomagnetism of the Werrie Block, northwestern Tamworth Belt, and the New England pole path. Australian Journal of Earth Sciences 50, 865-902.

KLOOTWIJK C. T. \& GIDDINGS J. W. 1988. An alternative APWP for the middle to late Palaeozoic of Australia-implications for terrane movement in the Tasman Fold Belt. Geological Society of Australia Abstracts 21, 219-220.

KoRsch R. J., Johnstone D. W. \& WAKe-DysteR K. D. 1997. Crustal architecture of the New England Orogen based on deep seismic reflection profiling. In: Ashley P. M. \& Flood P. G. eds. Tectonics and Metallogenesis of the New England Orogen, pp. 29-51. Geological Society of Australia Special Publication 19.

LEITCH E. C. 1993. The floor of the Gunnedah Basin north of the Liverpool Range. In: Tadros N. Z. ed. The Gunnedah Basin, New South Wales, pp. 335-348. Geological Survey of New South Wales Memoir Geology 12.

Li Z. X \& Powell C. McA. 1993. Late Proterozoic to Early Paleozoic paleomagnetism and formation of Gondwanaland. In: Findlay R. H., Unrug R., Banks M. R. \& Veevers J. J. eds. Gondwana 8: Assembly, Evolution and Dispersal, pp. 9-21. A. A. Balkema, Rotterdam.

LowE S. P. 1971. Stratigraphy of the Willow Tree district, New South Wales. BSc (Hons) thesis, University of New England, Armidale (unpubl.). 
LUDWIG K. R. 1999. User's manual for Isoplot/Ex, Version 2.10, a geochronological toolkit for Microsoft Excel. Berkeley Geochronology Center Special Publication 1a.

LUDWIG K. R. 2000. SQUID 1.00, a user's manual. Berkeley Geochronology Center Special Publication 2.

MANSER W. 1967. Stratigraphic studies of the Upper Palaeozoic and Post-Palaeozoic succession in the Upper Hunter Valley. MSc thesis, University of New England, Armidale (unpubl.).

MANSER W. 1968. Geological Map of New England 1:100 000, Wingen Sheet (No. 359) with Parts of Nos 350, 351, 360, with marginal text and 1:50,000 Map of the Timor Anticline. University of New England, Armidale, New South Wales, Australia.

McElhinny M. W., Powell C. McA. \& Pisarevski S. A. 2003. Paleozoic terranes of eastern Australia and the drift history of Gondwana. Tectonophysics 362, 41-65.

McKelvey B. C. \& McPhiE J. 1985. Tamworth Belt. In: Wagner R. H., Winkler P. C. F. \& Granados L. F. eds. The Carboniferous of the World II. Australia, Indian Subcontinent, South Africa, South America \& North Africa, pp. 15-23. Instituto Geologica y Minero de Espana \& Empressa Nacional ADARO de Investigaciones Mineras, S.A., Madrid.

McPHIE J. 1983. Outflow ignimbrite sheets from Late Carboniferous calderas, Currabubula Formation, New South Wales, Australia. Geological Magazine 120, 487-503.

MCPHIE J. 1984. Permo-Carboniferous silicic volcanism and palaeogeography on the western edge of the New England orogen, north-eastern New South Wales. Australian Journal of Earth Sciences 31, 133-146.

MCPHIE J. 1987. Andean analogues for Late Carboniferous volcanic arc and arc flank environments of the western New England Orogen, New South Wales, Australia. Tectonophysics 138, 269 288.

MCPhie J., Doyle M. \& AlLen R. 1993. Volcanic Textures. A Guide to the Interpretation of Textures in Volcanic Rocks. Centre for Ore Deposit and Exploration Studies. University of Tasmania, Hobart.

MenNing M. 2001. A Permian time scale 2000 and correlation of marine and continental sequences using the Illawarra Reversal (265 MA). In: Cassinis, G. ed. Permian Continental Deposits of Europe and other Areas. Regional Reports and Correlations, pp. 355-362. Natura Bresciana, Annali Museo Civico di Scienze Naturali di Brescia Monografia 25.

MOORE D. \& ROBERTS J. 1976. The Early Carboniferous marine transgression in the Merlewood Formation, Werrie Syncline, NSW. Journal and Proceedings of the Royal Society of New South Wales, 109, 49-58.

MoRY A. J. 1978. The geology of Brushy Hill, Glenbawn, New South Wales. Journal and Proceedings of the Royal Society of New South Wales, 111, 19-27.

MoRY A. J. \& CRANE D. T. 1982. Early Carboniferous Siphonodella (Conodonta) faunas from eastern Australia. Alcheringa 6, 275303.

Murray C. G., Fergusson C. L., Flood P. G., Whitaker W. G. \& KoRSCH R. J. 1987. Plate tectonic model for the Carboniferous evolution of the New England Fold Belt. Australian Journal of Earth Sciences 34, 213-236.

OfFEnBERG A. C. 1971. Tamworth 1:250 000 Geological Series Sheet SH 56-13. New South Wales Department of Mines, Sydney.

Opdyke N. D., Roberts J., Claoué-Long J. \& Jones P. J. 2000. Base of the Kiaman: its definition and global stratigraphic significance. Geological Society of America Bulletin 112, 13151341.

OsBORNE G. D. 1950. The structural evolution of the HunterManning-Myall province New South Wales. Royal Society of New South Wales Monograph 1.

Paces J. B. \& Miller J. D. 1993. Precise U-Pb ages of Duluth Complex and related mafic intrusions, northeastern Minnesota: geochronological insights to physical, petrogenetic, paleomagnetic, and tectonomagmatic process associated with the $1.1 \mathrm{Ga}$ Midcontinent Rift System. Journal of Geophysical Research 98, $13997-14013$.

RatTigan J. H. 1967. The Balickera section of the Carboniferous Kuttung facies, New South Wales. Journal and Proceedings of the Royal Society of New South Wales 100, 75-84.

ROBERTS J. 1975. Early Carboniferous brachiopod zones of Eastern Australia. Journal of the Geological Society of Australia 22, 1-31.
Roberts J., ClaOUÉ-Long J. C. \& JONES P. 1995a. Australian Early Carboniferous time. In: Berggren W. A., Kent D. V., Aubry M-P. \& Hardenbol J. eds. Geochronology, Time Scales and Global Stratigraphic Correlation, pp. 23-40. SEPM Special Publication 54.

Roberts J., Claoué-Long J. C., Jones P. \& Foster C. B. 1995b. SHRIMP zircon age control of Gondwanan sequences in Late Carboniferous and Early Permian Australia. In: Dunnay R. A. \& Hailwood A. E. eds. Non-biostratigraphical Methods of Dating and Correlation, pp. 145-174. Geological Society of London Special Publication 89.

RoBerTS J. \& ENGeL B. 1987. Depositional and tectonic history of the southern New England Orogen. Australian Journal of Earth Sciences 34, 1-20.

RoBerts J., Engel B. \& ChAPMAN J. 1991. Geology of the Camberwell, Dungog and Bullahdalah 1:100 000 Sheets 9133, 9233, 9333. Geological Survey of New South Wales, Sydney.

ROBERTS J. \& GEEVE R. 1999. Allochthonous forearc blocks and their influence on an orogenic timetable for the Southern New England Orogen. In: Flood P.G. ed. New England Orogen: Regional Geology, Tectonics and Metallogenesis, pp. 105-114. Earth Sciences, University of New England, Armidale.

Roberts J., Leitch E. C., LenNox P. G. \& OfFleR R. 1995c. Devonian-Carboniferous stratigraphy of the southern Hastings Block, New England Orogen, eastern Australia. Australian Journal of Earth Sciences 42, 609-634.

Roberts J., OFFLER R. \& FANNING M. 2004. Upper Carboniferous to Lower Permian volcanic successions of the CarrollNandewar region, northern Tamworth belt, southern New England Orogen, Australia. Australian Journal of Earth Sciences 51, 205-232.

RoBerTS J. \& Oversby B. S. 1974. The Lower Carboniferous geology of the Rouchel district, New South Wales. Bureau of Mineral Resources Bulletin 147.

ROBERTS J., WANG X. \& FANNING M. 2003. Stratigraphy and correlation of Carboniferous ignimbrites, Rocky Creek region, Tamworth Belt, Southern New England Orogen, New South Wales. Australian Journal of Earth Sciences 50, 931-954.

RunNegar B. N. 1970. The Permian faunas of northern New South Wales and the connection between the Sydney and Bowen Basins. Journal of the Geological Society of Australia 16, $697-710$.

SAXTon A. 1984. Geology of the Belltrees area New South Wales. BSc (Hons) thesis, University of Newcastle, Newcastle (unpubl.).

Scheibner E. \& Veevers J. J. 2000. Tasman Fold Belt System. In: Veevers J. J. ed. Billion-year Earth History of Australia and Neighbours in Gondwanaland, pp. 154-234. GEMOC Press, Sydney.

SCHMEDJE T. M. 1984. The geology of the Timor district. BSc (Hons) thesis, University of New South Wales, Sydney (unpubl.).

Schmidt P. W., Aubourge C., Lennox P. G. \& Roberts J. 1994. Palaeomagnetism and tectonic rotation of the Hastings Terrane, eastern Australia. Australian Journal of Earth Sciences 41, 547560.

SCHMidT P. W. \& MCELhINNY M. W. 2003. Discussion. Carboniferous palaeomagnetism of the Rocky Creek Block, northern Tamworth Belt, and the New England pole path. Australian Journal of Earth Sciences 50, 129-131.

Schmidt P. W., Powell C.McA., Li Z. X. \& Thrupp G. A. 1990. Reliabilty of Palaeozoic palaeomagnetic poles and APWP of Gondwanaland. Tectonophysics 184, 87-100.

STERN R. A. \& AMELIN Y. 2003. Assessment of errors in SIMS zircon $\mathrm{U}-\mathrm{Pb}$ geochronology using a natural zircon standard and NIST SRM 610 glass. Chemical Geology 197, 111-142.

StEVENSON D. K. 2003. Stratigraphy, lithology and depositional setting of the Cranky Corner Basin. In: Facer R. A. \& Foster C. B. eds. Geology of the Cranky Corner Basin, pp. 15-50. New South Wales Department of Mineral Resources, Coal and Petroleum Bulletin 4.

Sussmilch C. A. \& DAVID T. W. E. 1920. Sequence, glaciation and correlation in the Hunter River district, New South Wales. Journal and Proceedings of the Royal Society of New South Wales 53, 310-322.

Tera F. \& WAsserburg G. 1972. U-Th-Pb systematics in three Apollo 14 basalts and the problem of initial $\mathrm{Pb}$ in lunar rocks. Earth and Planetary Science Letters 14, 281-304. 
Trapp E., Kaufmann B., Korn D. \& Weyer D. 2004. Numerical calibration of the Devonian-Carboniferous boundary: two new $\mathrm{U}-\mathrm{Pb}$ isotope dilution-thermal ionisation mass spectrometry single-zircon ages from Hasselbachtal (Sauerland, Germany). Geology 32, 857-860.

VAN DER VOO R. 1990. The reliability of paleomagnetic data Tectonophysics 184, 1-9.

Voisey A. H. \& WiLliams K. L. 1964. The geology of the Carroll-Keepit-Rangari area of New South Wales. Journal and Proceedings of the Royal Society of New South Wales 97, 6572 .

WARNER D. S. 1972. Late Palaeozoic stratigraphy and sedimentation in the Murrurundi area New South Wales. BSc (Hons) thesis, University of New South Wales, Sydney (unpubl.).
WHETTEN J. T. 1965. Carboniferous glacial rocks from the Werrie Basin, New South Wales, Australia. Geological Society of America Bulletin 76, 43-56.

Williams E. A., Friend P. F. \& Williams B. P. J. 2000. A review of Devonian time scales: databases, construction and new data. In: Friend P. F. \& Williams B. P. J. eds. New Perspectives on the Old Red Sandstone, pp. 1-21. Geological Society of London Special Publication 180.

WILLIAMS I. S. 1998. U-Th- Pb geochronology by ion Microprobe. In McKibben M. A., Shanks W. C. III \& Ridley W. I. eds. Applications of Microanalytical Techniques to Understanding Mineralizing Processes, pp. 1-35. Reviews in Economic Geology 7.

Received 20 May 2005; accepted 31 October 2005

\section{APPENDIX 1: STRATIGRAPHIC UNITS}

Topographic maps referred to throughout the text and appendices of this paper include the Quipolly 9035-3-S, Emblem 9035-2-S, Quirindi 9034-4-N, Wallabadah 9034-1N, Warrah 9034-4-S, Temi 9034-1-S, Isis River 9134-4-S, Murrurundi 9034-2-N, Timor 9134-3-N, Parkville 9034-2-S, Waverley 9134-3-S, Scone 9033-1-N, Woolooma 9133-4-N, Aberdeen 9033-1-S, Rouchel Brook 9033-4-S, Muswellbrook 9033-2-N, and Dawsons Hill 9133-3-N 1:25 000 topographic sheets. Grid references are to the AGD66 datum. Abbreviations in round brackets after the names of members [e.g. Burnewang Ignimbrite Member (new name) (M2)] are those used to identify volcanic units in Plate 1 and Figures 2-14. The term micropoikilitic, applied to the texture of some ignimbrites, is used in the sense of McPhie et al. (1993).

\section{MERLEWOOD FORMATION (Voisey \& Williams 1964; McKelvey \& McPhie 1985)}

\section{Isismede Ignimbrite Member (new name) (MI)}

Name From the property Isismede (0319570E $6474300 \mathrm{~N}$ Timor 1:25 000 sheet).

Synonymy Isismede Member (Caldwell 1985).

Distribution Crops out discontinuously over about $1 \mathrm{~km}$ north of the end of Fullers Lane (Lewis Road) at Penmore (0297900E 6502160N Wallabadah 1:25000 sheet) $5 \mathrm{~km}$ southeast of Wallabadah. South of the Liverpool Range, there are discontinuous outcrops on Green Isis, Isis Hills, and Isismede (0314091E 6480509N; 0315682E $6476296 \mathrm{~N}$; and $0318577 \mathrm{E} 6474636 \mathrm{~N}$, respectively, Timor 1:25 000 sheet).

Type locality Locality 490-2 0318577E 6474636N (Timor 1:25 000 sheet) $\left(31^{\circ} 50^{\prime} 59^{\prime \prime} \mathrm{S}, 151^{\circ} 04^{\prime} 57^{\prime \prime} \mathrm{E}\right)$ at Isismede.

Thickness Maximum of $\sim 5 \mathrm{~m}$.

Lithology Pale-red, unwelded, ignimbrite containing scattered (5-10\%), fine to coarse phenocrysts (up to 2.5 $\mathrm{mm}$ in length) of plagioclase, opaque minerals and, at one locality each, minor hornblende and quartz. Pumice fragments have flow-foliated and vesicle-rich textures. Volcanic rock fragments rare. Shards undeformed, frequently broken, commonly triaxons and randomly to moderately well oriented; vesicles common and slightly deformed. Groundmass normally a chloritezeolite mosaic; micropoikilitic at locality 502-1 southeast of Wallabadah (0297700E 6504300N Wallabadah 1:25 000 sheet) close to an andesite sill. At Green Isis the ignimbrite contains interbeds of fine- to mediumgrained resedimented volcanolithic sandstone.

Age Three samples have been dated by SHRIMP AS3. Sample 501-4 (Figure 11c), from the Wallabadah district, has an age $351.7 \pm 3.2 \mathrm{Ma}$ and sample $470-13$ (Figure 11a), from Green Isis, an age of $352.4 \pm 3.2 \mathrm{Ma}$. The best estimate of age of sample 490-2 (Figure 11b), from Isismede, is $355.5 \pm 3.2$ Ma. Given problems of high common $\mathrm{Pb}$ in one session and a relatively low $\mathrm{U}$ content with sample 490-2 from Isismede, the most appropriate age is around $352 \mathrm{Ma}$. Early Carboniferous, Tournaisian.

\section{Burnewang Ignimbrite Member (new name) (M2)}

Derivation of name After the property Burnewang (0313820E 6482100N Timor 1:25 000 sheet).

Synonymy Wheelihans Gap Ignimbrite Member (Schmedje 1984).

Distribution Continuous but faulted outcrops from about $1 \mathrm{~km}$ north of the Blandford-Timor Road (0310525E 6483608N Murrurundi 1:25 000 sheet) on Rocklands to locality 491-3 (0314002E 6476000N Timor 1:25 000 sheet) on Isis Hills. Discontinuous outcrops are present at and adjacent to locality 488-2 (0315974E 6474511N) on the southern boundary of Isis Hills and on Waverley at locality 489-2 (0315707E 6472170N Timor 1:25 000 sheet). In the north, there is a single roadside exposure on Rockley (locality 465-13 0304002E 6494516N Temi 1:25 000 sheet).

Type locality Locality 478-19 (0311450E 6482787N Timor $1: 25000$ sheet) $\left(31^{\circ} 46^{\prime} 29^{\prime \prime} \mathrm{S}, 151^{\circ} 00^{\prime} 32^{\prime \prime} \mathrm{E}\right)$ in a cutting on a disused portion of the Blandford-Timor road, $1.5 \mathrm{~km}$ east of Wheelihans Gap.

Thickness $5-10 \mathrm{~m}$.

Lithology Bright-red, unwelded ignimbrite containing scattered (5-10\%), fine to coarse (up to $2.5 \mathrm{~mm}$ in length) phenocrysts of plagioclase, minor quartz, minor biotite and opaque minerals; specimen 488-2 (0315974E 6474511N Timor 1:25000 sheet) differs in possessing biotite. Pumice fragments generally small, elongate laths or lenticles with a fibrous or vesicle-rich texture. Rock fragments rare, mostly fine-grained devitrified volcanics but at times coarser ignimbrites. Shards and vesicles abundant, undeformed to slightly compressed and normally well oriented; triaxons common. Groundmass a fine mosaic of chlorite and zeolite. On Rockley, the 
ignimbrite at locality $465-13$ is composed of up to seven thin bands interbedded with crystal-rich, pink to brown epiclastic sandstone and ash and/or crystalbearing grey siltstone. Some ignimbrite bands appear to have been redeposited. Parts of the unit at locality 488-2 on Isis Hills contain pebble clasts and are probably reworked. XRF analyses of samples W18 from Rockley and W21A from the type locality indicate a rhyolitic composition; those from W15A, B, $1.1 \mathrm{~km}$ northwest of the type locality, are rhyolitic to rhyodacitic (Tables $22^{*}, 23^{*}$ ).

Age Three samples have been dated by SHRIMP AS3. Sample 465-13A (Figure 11d) $343 \pm 3 \mathrm{Ma}$; sample 472-1 (Figure 11e) $341.4 \pm 3.3 \mathrm{Ma}$; sample 488-2A (Figure 11f) $348.9 \pm 2.9 \mathrm{Ma}$. Given that Early Visean brachiopod faunas belonging to the Orthotetes australis Zone are present beneath the member at Green Creek and the Inflatia elegans Subzone at Isis Hills and Burnewang, the age of sample 488-2A is questionable. This is because the Curra Keith Ignimbrite Tongue of the Native Dog Member (349.6 $\pm 1.7 \mathrm{Ma}$ ) (Figure 13b) in the Rouchel district underlies both the above zones. The approximate age of the Burnewang Ignimbrite Member is taken as $343 \mathrm{Ma}$. Early to ?middle Visean.

Correlatives Unnamed ignimbrite B-D in the Isismurra Formation on Merric bears lithological resemblance with the Burnewang Ignimbrite but is slightly older, having an age of around $346 \mathrm{Ma}$.

\section{Wheelihans Gap Ignimbrite Member (new name) (M3)}

Derivation of name From Wheelihans Gap (0309900E $6482900 \mathrm{~N}$ Murrurundi 1:25 000 sheet) on the BlandfordTimor road.

Distribution Extends as two separate beds from 0308900E $6484950 \mathrm{~N}$ (Murrurundi 1:25 000 sheet) on Rocklands in the north to the Murrurundi Fault, south of which it is offset to the east by more than $1 \mathrm{~km}$. The ignimbrite extends for only $400 \mathrm{~m}$ south of the fault before being eroded by a disconformity at the base of the overlying Currabubula Formation. A single unit in the fault block immediately north of the Waverley Fault extends from about 0313000E 6475200N (Timor 1:25 000 sheet) in the north to locality 498-1 (0314343E 6471622N Waverley 1:25 000 sheet) $300 \mathrm{~m}$ east of Waverley Pinnacle in the south.

Type locality The interval between and including localities $469-43$ and $469-44$ (0309515E $6484148 \mathrm{~N}$ and 0309336E $6484228 \mathrm{~N}$, respectively, Murrurundi 1:25 000 sheet) ( $31^{\circ} 45^{\prime} 44^{\prime \prime} \mathrm{S}, 150^{\circ} 59^{\prime} 19^{\prime \prime} \mathrm{E}$ to $\left.31^{\circ} 45^{\prime} 41^{\prime \prime} \mathrm{S}, 150^{\circ} 59^{\prime} 13^{\prime \prime} \mathrm{E}\right)$. Thickness About $20 \mathrm{~m}$ in the type area, where there are two flows, and $10 \mathrm{~m}$ in the single flow at locality $488-15$ (0313229E 6474074N Timor 1:25 000 sheet), $1 \mathrm{~km}$ north of Waverley Pinnacle.

Lithology Fine, unwelded to slightly welded, grey, purple or beige ignimbrite with rare $(<5 \%)$ phenocrysts $(1-1.5 \mathrm{~mm})$ of plagioclase, minor quartz, and opaque minerals. Pumice fragments rare, thin laths oriented parallel with flow foliation of shards. Shards slender, undistorted to occasionally slightly flattened and normally aligned. Vesicles undistorted to slightly flattened. Groundmass micropoikilitic. XRF analyses (samples
W12, W14, W23B: Tables 22*, 23*) indicate a rhyolitic composition.

Age Sample 469-43 (Figure 13a) gives a SHRIMP AS3 age of $327.4 \pm 3.7$ Ma. Latest Visean to earliest Namurian.

\section{Unnamed Ignimbrite (M4)}

Distribution Unnamed ignimbrite M4 is present at the uppermost part of the Merlewood Formation in the fault block north of the Waverley Fault. From outcrops adjacent to an arcuate fault at about $0323830 \mathrm{E} 6475150 \mathrm{~N}$ (Timor 1:25 000 sheet), the ignimbrite extends southwards for more than $1 \mathrm{~km}$ along a ridge crest before descending southwestwards into Box Tree Creek where it is cut by a disconformity at the base of the Currabubula Formation. A reworked equivalent of the ignimbrite may be present above the Wheelihans Ignimbrite Member in the uppermost beds of the Merlewood Formation immediately below cliffs of Currabubula Formation at locality 498-2 (0314142E 6471573N Timor 1:25 000 sheet) at Waverley Pinnacle (section 489-498-499, Figure 3).

Thickness $\sim 7 \mathrm{~m}$ in section 488 .

Lithology Unwelded ignimbrite, pink and pumiceous at the base, beige medially and purple and pumiceous at the top. All parts contain fine to coarse phenocrysts $(0.5-2.5 \mathrm{~mm}$, rarely to $3.5 \mathrm{~mm})$ of quartz, plagioclase, biotite and opaque minerals; the upper part also with K feldspar. Pumice fragments are slivers, tabular or blocky with irregular edges; those in the upper part fine and lamellar. Rock fragments grey to beige devitrified or ferruginised volcanics. Shards and vesicles undeformed, and frequently broken. Groundmass a chloritic and zeolitic mosaic. An XRF analysis (sample W23A: Tables $22^{*}, 23^{*}$ ) indicates a rhyodacitic composition.

Age Sample 488-16C (Figure 12b) has a SHRIMP AS3 age of $328.1 \pm 2.9$ Ma. Latest Visean to earliest Namurian.

\section{CURRABUBULA FORMATION}

Synonymy Upper Kuttung Series (Lower Glacial, Interglacial and Upper Glacial Stages) (Carey 1937). Currabubula Formation (Voisey \& Williams 1964; McKelvey \& McPhie 1985). Rossmore Formation (in part) (Manser 1968).

Distribution Extends southwards from the northern closure of the Werrie Syncline south of Donnellys Gap (0270300E 6564500N Winton 1:25 000 sheet) along both limbs of the Werrie Syncline. Also in the Quipolly, Quirindi and Castle Mountain Domes, Back Creek Anticline, eastern and western limbs of the Temi Syncline, the eastern limb of which continues to the Waverley Fault.

Type locality The type section designated by Voisey and Williams (1964) is part of Carey's (1937) Woodlands section. Approximate coordinates for the base and top of the formation in the Woodlands section, derived from information in Carey (1937), are 0287100E $6534300 \mathrm{~N}$ and 0284200E 6535300N Goonoo Goonoo and Werris Creek 1:25 000 sheets, respectively. 


\section{Unnamed ignimbrite $(C 1)$}

Synonymy Ignimbrite Z (McPhie 1983). Gun Barrel Tuff Member (Cherry 1987).

Distribution Crops out between 0283100E 6503200N and 0283800E $6504800 \mathrm{~N}$ (Quirindi 1:25 000 sheet) south and north of Sick Sheep Creek, on the central-western part of the range of hills $3 \mathrm{~km}$ southeast of Braefield (0281370E 6505780N Quirindi 1:25 000 sheet).

Thickness Averages $30 \mathrm{~m}$ but as much as $60 \mathrm{~m}$ (Cherry 1987).

Lithology Unwelded, beige to grey ignimbrite with medium to coarse phenocrysts of quartz, plagioclase, minor biotite and opaque minerals. Pumice fragments rare, small, lensoidal to elongate, devitrified to a chlorite-zeolite mosaic and colourless zeolite crystals. Volcanic rock fragments rare. Shards thick, densely packed, arcuate to undulating and well oriented. Vesicles slightly deformed but largely broken. Groundmass normally strongly spherulitic but may also be a chlorite-zeolite mosaic or micropoikilitic.

Relationships McPhie (1983), using the terminology of ignimbrite $\mathrm{Z}$, proposed a correlation of unnamed ignimbrite $\mathrm{C} 1$ with the second highest ignimbrite, now the Rockford Ignimbrite Member, in the Currabubula Formation east of Kankool. Whilst both share similarities in mineralogy and texture, it is unlikely they are correlatives because unnamed ignimbrite $\mathrm{C} 1(\mathrm{Z})$ underlies the Cana Creek Tuff Member (McPhie 1983; Cherry 1987). The Cana Creek Tuff Member is older than the Taggarts Mountain Ignimbrite Member (SHRIMP AS3 age $319 \mathrm{Ma}$ ) (Roberts et al. 2004), whereas the Rockford Ignimbrite Member at Kankool (Ignimbrite Z of McPhie 1983) is bracketed by SHRIMP AS3 ages of $311.5 \pm 2.9 \mathrm{Ma}$ for the overlying Allawa Ignimbrite Member and $308.9 \pm 2.8 \mathrm{Ma}$ for the underlying Back Creek Ignimbrite Member. Unnamed ignimbrite $\mathrm{C} 1$ is clearly older than Rockford Ignimbrite Member.

Age Namurian.

\section{Cana Creek Tuff Member (C2)}

Derivation of name From Cana Creek, a transient stream which cuts through a range of hills $8.5 \mathrm{~km}$ northwest of Werris Creek and extends on to the Liverpool Plain. Synonymy Cana Creek Tuff Member (McPhie 1983; Opdyke et al. 2000).

Distribution In the Wallabadah district, the Cana Creek Tuff Member extends southwards along the western margin of White Rock Ridge almost to the Wallabadah-Quirindi Road, where it has been removed by a channel-like disconformity. The tuff reappears on the southern margin of Ponds Mountain and extends a further $6.5 \mathrm{~km}$ south-southeastwards to 0293100E $6502400 \mathrm{~N}$ (Wallabadah 1:25 000 sheet) adjacent to the junction between the Woodton Road and the now disused Kangaroo Creek Flat Road. Remnants of the tuff and epiclastic sandstone and pebble conglomerate are present on the same stratigraphic level immediately northwest of basalt cover on the crest of Big Double Mountain (0297490 6498550 Temi 1:25 000 sheet), on the southern slope of Big Double Mountain towards Chilcotts Creek and immediately south of Chilcotts
Creek homestead (at 0299004E 6496390N Temi 1:25000 sheet).

Type locality Cana Creek between 0268910E $6533450 \mathrm{~N}$ and $0269040 \mathrm{E}$ and $6533750 \mathrm{~N}$ (Werris Creek 1:25 000 sheet) $\left(31^{\circ} 18^{\prime} 37^{\prime \prime} \mathrm{S}, 150^{\circ} 34^{\prime} 18^{\prime \prime} \mathrm{E}\right.$ to $\left.31^{\circ} 18^{\prime} 27^{\prime \prime} \mathrm{S}, 150^{\circ} 33^{\prime} 45^{\prime \prime} \mathrm{E}\right)$.

Thickness $85 \mathrm{~m}$ in the type section in Cana Creek (Opdyke et al. 2000); $40 \mathrm{~m}$ in section 495 measured $0.5 \mathrm{~km}$ northwest of the southern end of main exposures of the tuff northeast of the junction of the Woodton-Kangaroo Creek Flat road (0293070E $6502600 \mathrm{~N}$ Temi 1:25 000 sheet).

Lithology In section 495, parts of the tuff consist of unwelded, pale-green, pumiceous ignimbrite containing coarse to fine phenocrysts of angular quartz, plagioclase and ?sanidine. Pumice fragments are mainly small, broken, laminated or fibrous, and contain abundant vesicles; larger pumice fragments are subquadrate with filamentous margins. Shards and vesicles are very coarse and frequently broken. Groundmass glassy to chloritic and zeolitic. Other parts are fine- to mediumgrained epiclastic sandstone with ash-rich bands. Epiclastic sandstone and conglomerate in the Big Double Mountain region contain grains and clasts of Cana Creek Tuff in a matrix of coarse shards, vesicles and pumice cemented by zeolite and chlorite. The tuff adjacent to Chilcotts Creek homestead is red but contains the same minerals and pumice fragments as the normal green variety. XRF analysis of sample W3 from outcrops adjacent to the Wallabadah-Woodton road indicates a rhyolitic composition (Tables $22^{*}, 23^{*}$ ). Age The Cana Creek Tuff Member has not been dated. In the Werrie Syncline, it is bracketed by two dated ignimbrites, an unnamed ignimbrite at Figtree Creek with a SHRIMP SL13 age of $313.6+3.6 \mathrm{Ma}$ (Opdyke et al. 2000) and the Taggarts Mountain Ignimbrite Member dated by SHRIMP AS3 at $319.3 \pm 2.8 \mathrm{Ma}$ (Roberts et al. 2004). Given the $2 \%$ difference in ages produced by the SL13 and AS3 standards (Black et al. 2003a), it is reasonable to assume that the Cana Creek Tuff Member is older than 319 Ma. Namurian.

\section{White Rocks Ignimbrite Member (new name) (C5)}

Derivation of name After White Rocks homestead (0288850E 6509810N Wallabadah 1:25 000 sheet).

Synonymy Ignimbrite W (McPhie 1983), Castle Mountain Tuff Member (Cherry 1987), White Rocks Tuff Member (Dawson 1988; Davies 1988).

Distribution Crops out on the eastern limb of the Werrie Syncline and in the Castle Mountain Dome. In the Werrie Syncline, there are two main bodies between Kangaroo Creek (0289770E 6507840N Wallabadah 1:25 000 sheet) and the western slope of Loders Peak (0288730E 6525100N Emblem 1:25 000 sheet). Two erosional remnants are present north of Jacob and Joseph Creek and west of Paradise Mountain, one immediately north of Edenhope (previously Tara) homestead and the other 1.5 $\mathrm{km}$ northwest of Edenhope; in the south, there is a single erosional remnant at $0290200 \mathrm{E} 650707120 \mathrm{~N}$ (Wallabadah 1:25 000 sheet). In the Castle Mountain Dome, a narrow belt extending between Bindawalla (0282000E 6508900N Quirindi 1:25 000 sheet) and Castle 
Mountain becomes broader and more widespread northeastwards towards Auburn Vale (0286500E $6508150 \mathrm{~N}$ Wallabadah 1:25 000 sheet). Extensive outcrops are also present $4 \mathrm{~km}$ southeast of Castle Mountain and 1 $\mathrm{km}$ northeast of Otter Estate (0283350E 6499570N Quirindi (1:25 000 sheet).

Type locality Locality 505-1 (0289796E 6507911N Wallabadah 1:25 000 sheet) $\left(31^{\circ} 32^{\prime} 40^{\prime \prime} \mathrm{S}, 150^{\circ} 47^{\prime} 09^{\prime \prime} \mathrm{E}\right)$ on the northern bank of Kangaroo Creek at Eastern Grange (formerly Wackatane) (0289550E 6507770N Wallabadah 1:25 000 sheet).

Thickness Normally $5-15 \mathrm{~m}$, but up to $23 \mathrm{~m}$ at the southernmost major outcrop at Kangaroo Creek (Davies 1988).

Lithology Davies (1988) and Dawson (1988) reported two main units in the White Rocks Ignimbrite Member, a lower, highly welded ignimbrite with a dark basal vitrophyre and an upper, much paler, ignimbrite. The latter unit, sampled in this study for dating, is a moderately welded beige ignimbrite containing scattered $(\sim 5 \%)$ fine to medium phenocrysts $(0.5-2 \mathrm{~mm})$ of plagioclase, minor hornblende and opaque minerals. Pumice fragments are small, numerous, subrectangular, lensoidal or subrounded and oriented parallel to the foliation. Rock fragments include rare devitrified volcanics. Shards are well oriented, arcuate to nearly flat and abundant. Vesicles are common. The groundmass is spherulitic. XRF analysis of a sample from the type locality indicates a rhyodacitic composition (sample W2: Tables $22 *, 23 *$ ).

Relationships The upper beige ignimbrite of the White Rocks Ignimbrite Member is virtually identical with the Castle Mountain Tuff Member of Cherry (1987). Three of Cherry's (1987) samples differ in containing quartz; two of these are also coarser grained.

Age Sample 505-1 (Figure 12e) has a SHRIMP AS3 age of $315.3 \pm 3.5$ Ma. Westphalian.

\section{Bindawalla Ignimbrite Member (new name) (C6)}

Derivation of name From the property Bindawalla (0282000E 6508900N Quirindi 1:25 000 sheet).

Synonymy Bindawalla Tuff Member (Cherry 1987).

Distribution Extends for about $1 \mathrm{~km}$ immediately northeast and east of Bindawalla on the northwestern margin of the Castle Mountain Dome. A second outcrop is present on the eastern margin of the dome $1 \mathrm{~km}$ southwest of Carinya (0288460E 6505740N Wallabadah 1:25 000 sheet).

Type locality Locality 507-2 (0282500E 6508928N Quirindi 1:25 000 sheet) $\left(31^{\circ} 32^{\prime} 03^{\prime \prime} \mathrm{S}, 150^{\circ} 42^{\prime} 14^{\prime \prime} \mathrm{E}\right)$ at Bindawalla.

Thickness 2-3 m (Cherry 1987).

Lithology Red to green unwelded ignimbrite containing rare $(<5)$ phenocrysts (up to $1 \mathrm{~mm}$ ) of quartz, plagioclase, biotite, and opaque minerals. Pumice fragments common, glassy, subcircular to rectangular, filamentous or vesicle-rich. Shards coarse, randomly oriented, triaxons common; vesicles undeformed, some aggregated. Groundmass chloritic and zeolitic.

Age Younger than the White Rocks Ignimbrite Member. Westphalian.

\section{Unnamed ignimbrite (C3)}

Distribution Known only in the vicinity of locality 5031 (0310692E 6471463N Parkville 1:25 000 sheet) in a thick succession of beige to pink lithic sandstone, conglomerate and minor siltstone exposed in a range of hills $3.2 \mathrm{~km}$ west of Waverley Pinnacle and west of Box Tree Creek (Figure 4 section 503). It does not crop out in the adjacent Camerons Gorge on the Pages River.

Thickness $20 \mathrm{~m}$.

Lithology Green unwelded ignimbrite with fine to coarse $(<0.5$ to rarely $3 \mathrm{~mm})$ phenocrysts $(20-30 \%)$ of plagioclase, quartz, biotite and opaque minerals. Pumice small, elongate, lensoidal and lamellar near the base, but larger and more blocky in mid- to upper parts of the ignimbrite. Rare fragments of a trachytic-textured volcanic. Shards and vesicles undeformed; triaxons present. Groundmass chloritic and zeolitic.

Age Sample 503-1 (Figure 12c) has a SHRIMP AS3 age of $319.1 \pm 2.8$ Ma. Westphalian.

\section{Unnamed ignimbrite (C4)}

Distribution An erosional remnant extending for $\sim 200 \mathrm{~m}$ southeast of locality 466-15 (0301627E $6491305 \mathrm{~N}$ Temi 1:25 000 sheet) at Warlands Creek, reappearing at locality 496-12 (0302486E 6491015N Temi 1:25 000 sheet) and extending for a further $400 \mathrm{~m}$ southeastwards along a ridge crest towards Greers Mountain.

Thickness $\sim 5 \mathrm{~m}$.

Lithology Brown welded ignimbrite with medium to coarse $(<0.5-2 \mathrm{~mm}$, rarely $4 \mathrm{~mm})$ phenocrysts $(25-30 \%)$ of plagioclase, sanidine, quartz, an altered $\mathrm{Fe} / \mathrm{Mg}$ mineral and opaque minerals. Pumice fragments large, lensoidal, coarsely recrystallised or spherulitic. Rock fragments (up to $14 \mathrm{~mm}$ ) mainly fine devitrified ignimbrites. Shards thick, flattened, strongly aligned. Vesicles almost flat. Groundmass chloritic to partially micropoikilitic.

Age Sample 466-15 (Figure 12d) has a SHRIMP AS3 age of $317.9 \pm 3.5 \mathrm{Ma}(\mathrm{MSWD}=1.8)$. Late Namurian.

\section{Kankool Ignimbrite Member (new name) (C11)}

Derivation of name From the Parish of Kankool (Temi 1:25 000 sheet).

Synonymy Back Creek Tuff Member (Kelk 1986).

Distribution A single major outcrop on the axis of the Kankool Anticline immediately adjacent to Back Creek, $1.7 \mathrm{~km}$ northeast of Temi homestead (Figure 4).

Type locality Locality 493-9 (0291334E 6489673N Temi 1:25 000 sheet) ( $\left.31^{\circ} 42^{\prime} 43^{\prime \prime} \mathrm{S}, 150^{\circ} 47^{\prime} 53^{\prime \prime} \mathrm{E}\right)$.

Thickness More than $10 \mathrm{~m}$, base not exposed.

Lithology Beige, unwelded ignimbrite with fine to medium $(<0.5-1.5 \mathrm{~mm}$, rarely $2 \mathrm{~mm})$ phenocrysts $(\sim 15 \%)$ of plagioclase, quartz, biotite and opaque minerals. Pumice small, mostly thin, elongate and lamellar or fibrous, others thicker with spherulitic to fibrous recrystallisation. Rock fragments fine-grained, ferruginous volcanics, some with feldspars. Shards slender, some triaxons, and poorly oriented; vesicles rare. Groundmass micropoikilitic. 
Age Sample 493-9 from the type locality has a SHRIMP AS3 age of $308.9 \pm 2.8 \mathrm{Ma}$. Westphalian. Since that is younger than that of the overlying Allawa Ignimbrite Member (SHRIMP AS3 $311.5 \pm 2.9 \mathrm{Ma}$ ), both ignimbrites are regarded as having an age of about $310 \mathrm{Ma}$. Westphalian.

\section{Chilcotts Creek Ignimbrite Member (new name) (C12)}

Derivation of name From Chilcotts Creek which extends from southeast of Big Double Mountain to Kankool.

Synonymy Chilcotts Creek Tuff Member (Kelk 1986).

Distribution Crops out extensively on both northern and southern sides of Chilcotts Creek south of Rockford (0290580E 6493200N Temi 1:25 000) in the axial region of the Kankool Anticline and in six separate outcrops, some separated by faults, on the western limb of the anticline between Back Creek in the north and Cenozoic basalts of the Liverpool Range in the south. A single outcrop on the eastern limb of the syncline occurs immediately north of the Liverpool Range (Figure 4).

Type locality Locality 493-4 (0290810E 6492293N Temi $1: 25000)\left(31^{\circ} 41^{\prime} 08^{\prime \prime} \mathrm{S}, 150^{\circ} 47^{\prime} 35^{\prime \prime} \mathrm{E}\right)$ in exposures north of Chilcotts Creek.

Thickness $\sim 15 \mathrm{~m}$ (Kelk 1986).

Lithology Beige, slightly welded to unwelded ignimbrite with fine to medium (up to $1.5 \mathrm{~mm}$, rarely $2 \mathrm{~mm}$ ) phenocrysts (up to 14\%: Kelk 1986), of feldspar minor biotite and opaque minerals. Pumice elongate, thin and fibrous to laminated or thick with spherulitic recrystallisation. Rock fragments of beige glassy or banded ignimbrite and grey devitrified volcanic. Groundmass micropoikilitic (sample 493-4, 0290810E 6492293N). Sample 288-1 from beneath the main flow on Chilcotts Creek $(0293000 \mathrm{E} 6493500 \mathrm{~N})$ and a breccia from sample $493-2$ $(0291383 \mathrm{E} 6488962 \mathrm{~N})$ on Temi Station both contain quartz. Similar, possibly resedimented, rocks are present north of the main outcrops south of Rockford $(0290550 \mathrm{E} 6493200 \mathrm{~N}$; all grid references to the Temi 1:25 000 sheet).

Age Westphalian.

\section{Rockford Ignimbrite Member (new name) (C13)}

Derivation of name After the property Rockford (0290580E 6493200N Temi 1:25 000 sheet).

Synonymy Highlands Tuff Member (Kelk 1986).

Distribution Crops out south of Chilcotts Creek on both limbs of the Back Creek Anticline (Figure 4). On the eastern limb, outcrops extending for more than $2 \mathrm{~km}$ south of Chilcotts Creek and north of Back Creek are disconformably overlain by the Woodton Formation; three other scattered outcrops are present between Back Creek and the Liverpool Range (Kelk 1986). Two extensive outcrops separated by a fault are present on the western limb of the anticline north of Temi homestead, and a further two small outcrops have been identified on the road between the New England Highway and Mt Helen at the crest of the Liverpool Range (Kelk 1986); that at locality 641-8 (0291083E 6486491N
Murrurundi 1:25000 sheet) is petrologically identical with the main eastern outcrops of the Rockford Ignimbrite Member.

Type locality Locality 493-1 0291873E 6490109N Temi 1:25 000 sheet $\left(31^{\circ} 40^{\prime} 38^{\prime \prime} \mathrm{S}, 150^{\circ} 47^{\prime} 27^{\prime \prime} \mathrm{E}\right)$.

Thickness Up to $20 \mathrm{~m}$ (Kelk 1986).

Lithology Purple to beige, unwelded to possibly slightly welded ignimbrite. Medium to coarse (up to $1.5-2 \mathrm{~mm}$ ) phenocrysts (11-15\%: Kelk 1986) of plagioclase, rare ?K feldspar, quartz, biotite, opaque minerals and minor pumice and rock fragments. Shards thick, arcuate, randomly oriented to partly moderately well aligned. Vesicles slightly flattened. Groundmass micropoikilitic. Age Westphalian.

\section{Allawa Ignimbrite Member (new name) (C14)}

Derivation of name After the property Allawa (0288510E 6490950N Temi 1:25000 sheet).

Synonymy Allawa Tuff Member (Kelk 1986).

Distribution Crops out in one large and two small bodies on the western limb of the Kankool Anticline east of Doughboy Creek, midway between Temi and the Chilcotts Creek road (Figure 4).

Type locality Locality 493-3 (0290289E 6490848N Temi $1: 25000$ sheet) $\left(31^{\circ} 41^{\prime} 54^{\prime \prime} \mathrm{S}, 150^{\circ} 47^{\prime} 14^{\prime \prime} \mathrm{E}\right)$ at the northern edge of the main exposure.

Thickness $10 \mathrm{~m}$ (Kelk 1986).

Lithology Beige unwelded ignimbrite with small (up to $1.5 \mathrm{~mm}$ ) phenocrysts (16\%: Kelk 1986) of plagioclase, ?Kfeldspar, quartz, minor biotite and opaque minerals. Pumice fragments uncommon, small, elongate, lamellar and recrystallised. Rock fragments beige and ferruginised, fine-grained volcanics. Shards slender, randomly oriented; triaxons common. Vesicles slightly flattened but normally broken. Groundmass micropoikilitic. Kelk (1986) described the member as being crystal-rich and partially to completely welded, but variable along strike.

Age Sample 493-9 (Figure 13a) has a SHRIMP AS3 age of $311.5 \pm 2.9 \mathrm{Ma}$. Since that unit is older than the underlying Kankool Ignimbrite Member, both are considered to be about $310 \mathrm{Ma}$ in age. Westphalian.

\section{Unnamed pyroxene dacite member Cpx}

Synonymy Two pyroxene Andesite (Kelk 1986).

Distribution Two main outcrops are present south of Temi homestead; in a re-entrant into Cenozoic basalt on the northern side of the Liverpool Range, and northeast of Ardglen between the New England Highway and the Liverpool Range (Figure 4).

Thickness $<10 \mathrm{~m}$ (Kelk 1986).

Lithology Grey to black dacite with coarse phenocrysts of plagioclase, augite and hypersthene. Groundmass glassy or a devitrified mosaic of chlorite and zeolite. XRF analysis of a sample from cuttings near Temi indicates a dacitic composition (sample LM29: Tables $22^{*}, 23^{*}$ ). Kelk (1986) was uncertain whether the dacite was a flow or a sill because poor exposures at the margins prevented a determination of the type of contact with surrounding sedimentary rocks.

Age Possibly Late Carboniferous or Permian. 


\section{Unnamed rhyodacite member (C7)}

Distribution Crops out over about $0.5 \mathrm{~km}$ from section $570 \quad(0294638 \mathrm{E} \quad 6485250 \mathrm{~N}$ to locality $633-3 \quad(0294219 \mathrm{E}$ $6485618 \mathrm{~N}$ Temi 1:25 000 sheet) on the southern slope of the Liverpool Range north of Murrurundi east of Cohens Gully (Figure 6).

Thickness $\sim 5 \mathrm{~m}$.

Lithology Beige to grey rhyodacite lava with medium to coarse (up to $3 \mathrm{~mm}$ ) phenocrysts $(\sim 15-20 \%$ ) of plagioclase, some in aggregates with opaque minerals up to 4.5 $\mathrm{mm}$. Groundmass contains unoriented, felted, feldspars, and minor zeolite and opaque minerals.

Age Westphalian.

\section{Murrurundi Ignimbrite Member (new name) (C8)}

Derivation of name From the town of Murrurundi. Distribution Two distinct belts of outcrop, one extending eastwards for more than $1 \mathrm{~km}$ from Section 641, $0.5 \mathrm{~km}$ east of the Mt Helen Road near Ardglen, and the second for about $2 \mathrm{~km}$ in the vicinity of Cohens Gully (Figure 6). The apparent replacement of the ignimbrite by volcanolithic sandstone in Section 572A (Figure 7) may indicate erosion in that area.

Type locality Cutting on a track in Murrurundi Common between localities 572B-17 and 16 (0292555E $6486090 \mathrm{~N}$ and $0292525 \mathrm{E} 6486143 \mathrm{~N}$ Temi 1:25 000 sheet) $\left(31^{\circ} 44^{\prime} 30^{\prime \prime} \mathrm{S}, 150^{\circ} 48^{\prime} 37^{\prime \prime} \mathrm{E}\right.$ and $\left.31^{\circ} 44^{\prime} 28^{\prime \prime} \mathrm{S}, 150^{\circ} 48^{\prime} 35^{\prime \prime} \mathrm{E}\right)$.

Thickness $70 \mathrm{~m}$ in the type section to $25 \mathrm{~m}$ in Section 640.

Lithology Unwelded, red to pink ignimbrite containing fine to mainly coarse $(<0.5-2.5 \mathrm{~mm}$, rarely $3 \mathrm{~mm})$ phenocrysts $(\sim 20 \%)$ of plagioclase, embayed quartz, rare biotite and opaque minerals. Pumice fragments tabular to lensoidal and devitrified to a fine chloritezeolite mosaic, or partially glassy, laminated or flow banded with abundant vesicles. Rock fragments uncommon, mainly ignimbrites. Shards are thick, abundant, and undeformed. Vesicles are large and abundant. Glass in the groundmass is largely replaced by a fine chloritezeolite mosaic. The unit is commonly ferruginised.

Age Probably Westphalian.

\section{Cohens Gully Ignimbrite Member (new name) (C9)}

Derivation of name From Cohens Gully, a tributary of the Pages River, north of Murrurundi.

Distribution Two belts of outcrop are present between the Mt Helen Road near its junction with the New England Highway and locality 640-4 (0294688E 6485727N Temi 1:25 000 sheet) (Figures 6, 7). A gap in the ignimbrite of approximately $1 \mathrm{~km}$ in the region adjacent to sections $572 \mathrm{~A}$ and $\mathrm{B}$ contains sedimentary rocks, suggesting erosion of the ignimbrite in that region.

Type locality Southern slope of the Liverpool Range, northwards from locality 634-6 (0293569E 6485948N) to $0293600 \mathrm{E} 6484065 \mathrm{~N}$, Temi $1: 25000$ sheet $\left(31^{\circ} 44^{\prime} 35^{\prime \prime} \mathrm{S}\right.$, $150^{\circ} 49^{\prime} 15^{\prime \prime} \mathrm{E}$ to $31^{\circ} 44^{\prime} 36^{\prime \prime} \mathrm{S}, 150^{\circ} 49^{\prime} 15^{\prime \prime} \mathrm{E}$ ).

Thickness $70 \mathrm{~m}$ in the type section to $10 \mathrm{~m}$ in Section 640 .
Lithology Unwelded, pink, green or red ignimbrite containing phenocrysts $(<0.5-2 \mathrm{~mm}, \sim 25 \%)$ of plagioclase, quartz, abundant biotite and opaque minerals. Pumice fragments common in upper part of flow, rounded to elongate and diffuse. Felsic ignimbrite and lava fragments are rare. Shards are small, frequently broken, and poorly to moderately aligned. Vesicles are common and little deformed. The groundmass is largely devitrified to a fine chlorite-zeolite mosaic. The eastern extremity of the member contains scattered pebbles.

Age Probably Westphalian.

\section{Mt Helen Rhyodacite Member (new name) (C10)}

Derivation of name From Mt Helen at the top of the Liverpool Range north of Murrurundi (0295630E 0287600N Temi 1:25 000 sheet).

Distribution The flow is confined to the central part of the Murrurundi Range between localities 633-1 and 640-9 (0294625E 6485909N and 0295085E 6485400N, respectively, Temi 1:25 000 sheet). It forms a prominent arcuate ridge and is cut by faults at its eastern extremity (Figure 6). Type locality Locality 570-4 0294811E 6485755N Temi 1:25 000 sheet $\left(31^{\circ} 44^{\prime} 43^{\prime \prime} \mathrm{S}, 150^{\circ} 50^{\prime} 02^{\prime \prime} \mathrm{E}\right)$.

Thickness $20 \mathrm{~m}$ at the type locality.

Lithology Grey to purple rhyodacite lava containing coarse (up to $3 \mathrm{~mm}$ ) phenocrysts $(\sim 10 \%)$ of plagioclase, some aggregated, and minor opaque minerals. Fine, felted, feldspars in groundmass are flow foliated.

Age Probably Westphalian.

\section{Karralee Ignimbrite Member (new name) (C15)}

Derivation of name From the property Karralee (0293850E 6484620N Murrurundi 1:25 000 sheet) on the northwestern outskirts of Murrurundi.

Distribution Extends for $\sim 2 \mathrm{~km}$ from locality 638-9 (0295477E 6485314N Temi 1:25 000 sheet) on a ridge adjacent to Spring Creek to the western slope of $\mathrm{Mt}$ Pleasant (Figure 6); two separate ignimbrites are present in the latter area (Figure 8, Section 571, localities 3,4$)$.

Type locality Locality 637-7 (0296105E 6485007N Murrurundi 1:25 000 sheet) ( $\left.31^{\circ} 45^{\prime} 08^{\prime \prime} \mathrm{S}, 150^{\circ} 50^{\prime} 51^{\prime \prime} \mathrm{E}\right)$.

Thickness $\sim 10 \mathrm{~m}$ at locality $637-29$ (0295895E $6485138 \mathrm{~N}$ Murrurundi 1:25 000 sheet).

Lithology Purple to brown, welded to unwelded ignimbrite with rare, coarse (up to $2.5 \mathrm{~mm}$ ) phenocrysts (5-10\%) of plagioclase, minor K-feldspar and sanidine, minor quartz and opaque minerals. In the type area, lower part strongly flow foliated, with prominent fiamme and large tabular pumices; upper part containing scattered phenocrysts in a spherulitic groundmass. Elsewhere, the ignimbrite is characterised by a foliated pumiceous groundmass (locality 637-29), well-defined shards and vesicles (localities 638-4 0296151E 6484752N Murrurundi 1:25 000 sheet and 638-9 029547E 6485314N Temi 1:25 000 sheet). Groundmass a zeolite-chlorite mosaic, or micropoikilitic.

Relationships In the vicinity of Spring Creek, the Karralee Ignimbrite Member is interbedded between 
less extensive, unnamed rhyodacite flows. Both are grey to beige and contain scattered medium to large phenocrysts of plagioclase in a groundmass containing slender, well-oriented laths of feldspar, chlorite and chalcedony. The stratigraphic position of the Karallee Ignimbrite Member within the Currabubula Formation is unclear because it is restricted to a single fault block. It could either be older or younger than the volcanic succession established within the Currabubula Formation between the Liverpool Range and the Back Creek Anticline.

Age Probably Westphalian.

\section{WOODTON FORMATION (new name)}

Derivation of name After the property Woodton (0295400E 6499250N Wallabadah 1:25 000 sheet).

Synonymy Inglewood Mudstone and Kankool Formation (Lowe 1971). Inglewood Mudstone (Warner 1972). Inglewood Formation (Kelk 1986; Cherry 1987; Davies 1988). Tara Formation (Hockley 1966; Dawson 1988).

Distribution The Woodton Formation is present along the eastern limb of the Werrie Syncline from $0.7 \mathrm{~km}$ north of the Wallabadah-Quirindi road to the northern flank of the Liverpool Range south of Chilcotts Creek; on the southeastern margin and centre of Quipolly Dome; northern and eastern margins of the Castle Mountain Dome; the closure and both limbs of the Back Creek Anticline, including two small inliers on an unnamed tributary of Borambil Creek, $4 \mathrm{~km}$ east of Willow Tree (Lowe 1971); and both limbs of the Temi Syncline, with exposures on the eastern limb limited to the region adjacent to Greers Mountain and Scotts Creek.

Type locality The type section is taken at a section measured by Kelk (1986) along Back Creek from the junction between undifferentiated Currrabubula Formation at $0292550 \mathrm{E} 6489250 \mathrm{~N}$ to the end of exposures at 0293800E 6489150N (Temi 1:25 000 sheet) $\left(31^{\circ} 42^{\prime} 48^{\prime \prime} \mathrm{S}\right.$, $150^{\circ} 48^{\prime} 39^{\prime \prime} \mathrm{E}$ to $31^{\circ} 42^{\prime} 52^{\prime \prime} \mathrm{S}, 150^{\circ} 29^{\prime} 46^{\prime \prime} \mathrm{E}$ ) (Figure 4). A subsidiary section illustrating the upper boundary of the Woodton Formation (Kelk 1986) extends along Chilcotts Creek from (0292200E 6492800N) to the base of the Willawarra Rhyodacite (0293200E 6493180N Temi $1: 25000$ sheet) $\left(31^{\circ} 40^{\prime} 52^{\prime \prime} \mathrm{S}, 150^{\circ} 48^{\prime} 18^{\prime \prime} \mathrm{E}\right.$ to $31^{\circ} 40^{\prime} 41^{\prime \prime} \mathrm{S}$, $\left.150^{\circ} 49^{\prime} 06^{\prime \prime} \mathrm{E}\right)$.

Thickness The type section, in which the top of the formation is unexposed, is greater that $230 \mathrm{~m}$; the subsidiary section in which the base is unexposed is about $215 \mathrm{~m}$. Other measurements include $85 \mathrm{~m}$ at Old Quipolly Dam $10.5 \mathrm{~km}$ northeast of Quirindi, $115 \mathrm{~m}$ on Jacob \& Joseph Creek west of Tara (0288200E 6515450N Emblem 1:25 000 sheet) (Dawson 1988), $233 \mathrm{~m}$ on Inglewood (0292540E $6502050 \mathrm{~N}$ Wallabadah 1:25 000 sheet) (Davies 1988), $96 \mathrm{~m}$ in section 480 on Chilcotts Creek immediately east of 0297600E 6496350N (Temi 1:25 000 sheet) and $\sim 900 \mathrm{~m}$ on the western limb of the Temi Syncline east of Mt Pleasant (Figure 9 sections 571, 632 and 539); the faulted section at Scotts Creek (section 467, Figure 3) is $\sim 240 \mathrm{~m}$ thick.

Lithology The Woodton Formation is typified by laminated to massive mudstone and siltstone and minor volcanolithic sandstone, conglomerate and diamictite.
Rhyodacitic lavas and ignimbrites are present only at the top of the Woodton Formation in the Back Creek Anticline and within the unit on the southwestern and southeastern flanks of the Temi Syncline. Kelk's (1986) description of the most common lithologies is summarised as follows. Mudstones and siltstones are green, brown, or beige, laminated forms having graded laminae between 1 and $20 \mathrm{~mm}$ thick. Dropstones up to $100 \mathrm{~mm}$ in diameter and soft-sediment folds and slumps are present in both mudstones and sandstones. Volcanolithic sandstones are fine- to medium-grained, well sorted, massive, graded, or slightly rippled, and may contain mudstone clasts. Diamictites are generally sandy and contain granules, pebbles, and rare cobbles; current ripples are present at the base of a pebble diamictite in Doughboy Hollow Creek on Temi Station. Conglomerates are similar to those in the Currabubula Formation. Laminated siliceous, ash-rich mudstone, and siltstone are present in the Quipolly Dome, outcrops east of Willow Tree, and in the Temi Syncline at Warlands Creek gorge and between Greers Mountain and immediately east of Scotts Creek. In the eastern part of Quipolly Dome, the main lithologies are pink, green, or beige, zeolitised, laminated, ash-rich siltstone with carbonaceous bands and interbeds of fine- to mediumgraded sandstone, white to brown mudstone, commonly with soft-sediment deformation structures, and intraformational breccia (Dawson 1988). At Warlands Creek gorge, north of Barongarook (0300500E 6482500N Murrurundi 1:25 000 sheet), white to grey, or purple, laminated and cross-bedded cherty siltstone is associated with the Warlands Creek Volcanic and Barongarook Ignimbrite Members. Thinly bedded, pink to green, ash-rich siltstones accompany the Brogans Rhyodacite Member at Scotts Creek.

Depositional environment Laminated and massive mudstone, dropped pebbles, diamictite and both graded and well-sorted sandstone, some of which is rippled, and lensoidal conglomerates are compatible with a glaciolacustrine environment of deposition. The prevalence of lavas accompanied by siliceous siltstones in the region adjacent to the Murrurundi Fault suggest a lacustrine environment close to a volcanic source.

Relationships The Woodton Formation disconformably overlies the Currabubula Formation and is overlain disconformably by either the Lower Permian Temi Formation or Werrie Basalt.

Age The Woodton Formation is younger than the Allawa and Back Creek Ignimbrite Members $(311.5 \pm 2.9$ and $308.9 \pm 2.8 \mathrm{Ma}$, respectively) in the underlying Currabubula Formation, and older than the Early Permian Temi Formation and Werrie Basalt. Plant fossils originally identified as glossopterid leaves were collected by Lowe (1971) from 0288265E 6496214N (Temi 1:25 000 sheet) on the banks of an unnamed tributary of Borambil Creek on Gemmawalla (0288550E 6498890N Temi 1:25 000 sheet). Warner (1972) subsequently re-identifed the material as Cardiopteris sp., thus changing the age to Carboniferous. Reassessment of the specimens by R. Gould (unpubl. data) indicates a leaf that may be Gangamopteris and a strap-like impression that could be assigned to Noeggerathiopsis. Both of these genera indicate a Permian age. Sample 
287-2A (Figure 13b) has a SHRIMP AS3 age of $290.5 \pm$ 2.8 Ma, which is Early Permian (Menning 2001). Asselian.

\section{Brogans Rhyodacite Member (N4)}

Derivation of name From Brogans Gully, a tributary of Scotts Creek, $8 \mathrm{~km}$ northeast of Blandford.

Synonymy Brogans Tuff Member (Manser 1968).

Distribution Crops out between 030550E 6487520N at the eastern end of Greers Mountain and 0306824E 6485556N (Temi 1:25 000 sheet) $0.5 \mathrm{~km}$ east of Scotts Creek.

Type locality Locality 287-2 roadside and creek exposures (0306450E 6486320N Temi 1:25000 sheet) ( $\left.31^{\circ} 44^{\prime} 32^{\prime \prime} \mathrm{S}, 150^{\circ} 57^{\prime} 24^{\prime \prime} \mathrm{E}\right)$.

Thickness $\sim 8 \mathrm{~m}$.

Lithology A pink rhyodacite lava containing scattered medium to coarse (up to $4 \mathrm{~mm}$ ) phenocrysts $(\sim 10 \%)$ of plagioclase, rare quartz and biotite, fine-grained, irregular accumulations of chalcedony and opaque minerals. The groundmass has fine, slender, felted plagioclase laths and small irregular areas of chalcedony. Uppermost part with foliated, contorted and broken folds. Foliation in the folds varies from fine to coarse (up to $4 \mathrm{~mm}$ thick), the bands being delineated by accumulations of thin or globular pumice fragments or accumulations of opaque minerals overlain by fibrous crystals of zeolite and chlorite. This suggests that the uppermost surface of the flow has been preserved. XRF analysis of a samples from the type area indicates a rhyodacitic composition (samples W17A, W17B: Tables $\left.22^{*}, 23^{*}\right)$.

Age Sample 287-2A (Figure 13b) has a SHRIMP AS3 age of $290.5 \pm 2.8 \mathrm{Ma}$. Asselian.

\section{Blandford Rhyodacite Member (new name) (N1)}

Derivation of name After the town of Blandford on the New England Highway.

Distribution An arcuate belt extends for $2 \mathrm{~km}$ from the northern part of Mt Pleasant to the northern end of a southeast-trending ridge northwest of Blandford Park (0299480E 64821450N Temi 1:25 000 sheet) (Figure 6).

Type locality Locality 571-13 at Mt Pleasant (0297083E $6485044 \mathrm{~N}$ Murrurundi 1:25000 sheet) (31 $45^{\prime} 07^{\prime \prime} \mathrm{S}$, $\left.150^{\circ} 51^{\prime} 28^{\prime \prime} \mathrm{E}\right)$.

Thickness $7-10 \mathrm{~m}$.

Lithology Beige to white rhyodacite lava with scattered medium to coarse $(0.5-3 \mathrm{~mm})$ phenocrysts $(15-20 \%)$ of plagioclase and fine opaque minerals. Groundmass of slender to subquadrate feldspar laths, slender forms exhibiting well-developed flow foliation.

Age Asselian.

\section{Warlands Creek Volcanic Member (N2)}

Derivation of name Warlands Creek which extends from Wallabadah Rocks to the Pages River at Blandford. Synonymy Warlands Creek Tuff Member (Manser 1967, 1968); Barangarook Tuff Member (Warner 1972).

Distribution Extends from basalt cover at the Liverpool Range (0296500E 6486300N Temi 1:25 000 Sheet) to within $0.5 \mathrm{~km}$ of the southern margin of Warlands Creek gorge, $4.5 \mathrm{~km}$ east of Murrurundi (Plate 1, Figure 6).

Type locality Continuous outcrop on Warlands Creek between $0299687 \mathrm{E} 6483681 \mathrm{~N}$ and $0299603 \mathrm{E} 6484386 \mathrm{~N}$ Murrurundi $1: 25000$ sheet) $\left(31^{\circ} 45^{\prime} 53^{\prime \prime} \mathrm{S}, 150^{\circ} 53^{\prime} 06^{\prime \prime} \mathrm{E}\right.$ to $31^{\circ} 45^{\prime} 30^{\prime \prime} \mathrm{S}, 150^{\circ} 53^{\prime} 03^{\prime \prime} \mathrm{E}$ ), about $4 \mathrm{~km}$ north-northwest of Blandford, as designated by Manser (1967).

Thickness $25 \mathrm{~m}$ at the type locality.

Lithology In the region immediately adjacent to Warlands Creek, the member is a beige to grey welded, partly flow-foliated ignimbrite with scattered medium to coarse phenocrysts $(<0.5-3.5 \mathrm{~mm}$, rarely $4 \mathrm{~mm}$; $\sim 15 \%$ ) of plagioclase, minor quartz and opaque minerals. Pumice fragments at the base of the flow are absent elsewhere. Shards are largely obscured by recrystallisation but appear to be mainly flattened and well oriented. Groundmass spherulitic to micropoikilitic. North of Second Oakey Creek, between Warlands Creek and Cenozoic basalt of the Liverpool Range, the member contains a wide variety of lithologies. From the base, these include fine, beige to pink lavas and welded ignimbrite with scattered phenocrysts $(1-2 \mathrm{~mm}$; $\sim 15 \%$ ) of plagioclase, and epiclastic sandstone and conglomerate; ignimbrite identical with that in the type area but interbedded with epiclastic sandstone and conglomeratic equivalents; and at the top, grey to beige unwelded ignimbrite with phenocrysts $(>0.5-$ $2 \mathrm{~mm}$, rarely $>2 \mathrm{~mm} ; 20 \%$ ) of plagioclase, minor $\mathrm{K}$ feldspar, quartz, biotite and opaque minerals. The basal lava is similar to a rhyodacite lava (locality 632-11 0298500E 6484194N Murrurundi 1:25 000 Sheet) $40 \mathrm{~m}$ beneath the main southern body of the Warlands Creek Volcanic Member west of Warlands Creek (section 632, Figure 8).

Age Asselian.

\section{Barongarook Ignimbrite Member (new name) (N3)}

Name From the property Barongarook (0300820E 6482750N Murrurundi 1:25 000 sheet).

Distribution A single belt of outcrop $\sim 1 \mathrm{~km}$ in length along the mid-western slope of a prominent, unnamed hill between Warlands Creek gorge and the Warlands Creek Road, $3 \mathrm{~km}$ north of Blandford (Figure 6).

Type locality Locality 637-7 (0300006E 6483858N Murrurundi $1: 25000$ sheet) $\left(31^{\circ} 45^{\prime} 48^{\prime \prime} \mathrm{S}, 150^{\circ} 53^{\prime} 18^{\prime \prime} \mathrm{E}\right)$.

Thickness $12 \mathrm{~m}$.

Lithology Beige, unwelded ignimbrite with small to medium ( $<0.5-2 \mathrm{~mm}$, rarely $3 \mathrm{~mm} ; \sim 20-25 \%)$ phenocrysts of plagioclase \pm minor biotite and opaque minerals. Pumice fragments with variable shapes, abundance, and devitrification; large fragments mostly coarsely devitrified. Rock fragments include lavas and ignimbrites. Shards arcuate and triaxons, randomly to moderately well oriented. Vesicles undeformed, slightly flattened, or broken. Groundmass a chlorite-zeolite mosaic with rare spherulites.

Relationships Approximately stratigraphically equivalent to, but lithologically different from, a beige, eutaxitic ignimbrite with large $(3 \mathrm{~mm})$ phenocrysts of plagioclase, biotite and opaque minerals, and elongate and small fiamme at locality 593-7 (0299860E 6484516N 
Murrurundi 1:25 000 sheet) $0.5 \mathrm{~km}$ to the north. A rhyodacite lava containing large phenocrysts of feldspar in a fine felted groundmass is present above the Barongarook Ignimbrite Member at locality 643-10 (0300194E 6484084N Murrurundi 1:25 000 sheet) near the top of the Woodton Formation.

Age Asselian.

\section{Willawarra Rhyodacite Member (new name) (N5)}

Name From the property Willawarra (0288780E 6492300N Temi 1:25 000 sheet).

Synonymy Willawarra Dacite (Lowe 1971). Willawarra Rhyodacite (Kelk 1986).

Distribution Extensive outcrops are present on the eastern and northwestern limbs of the Back Creek Anticline. That on the eastern limb extends northwards from Back Creek towards the northern closure of the syncline $1.7 \mathrm{~km}$ northwest of The Basins $(0292880 \mathrm{E}$ 6493020N Temi 1:25 000 sheet) where it either disappears beneath Cenozoic basalt or has been removed by erosion. That on the western limb extends from south of Little Jack White Mountain (0289900E 6494700N Temi 1:25 000 sheet) to Willawarra (0288780E 649230N0 Temi 1:25 000 sheet) where it is either overlain, eroded out, or faulted against Lower Permian Werrie Basalt and also covered by alluvium.

Type locality Exposures along Chilcotts Creek between 0293200E and 6493180N and 0293200E 6493180N (Temi 1:25 000 sheet) (modified from Kelk 1986) (31 $40^{\circ} 41^{\prime \prime} \mathrm{S}$, $150^{\circ} 49^{\prime} 06^{\prime \prime} \mathrm{E}$ to $31^{\circ} 40^{\prime} 21^{\prime \prime} \mathrm{S}, 150^{\circ} 49^{\prime} 11^{\prime \prime} \mathrm{E}$ ) near The Basins. Good exposures are also present in road cuttings north of The Basins.

Thickness $\sim 350 \mathrm{~m}$ at The Basins (Kelk 1986).

Lithology Beige to white flow-banded (1.5-4 mm) rhyodacite lava containing fine to medium $(<0.5-2$ $\mathrm{mm} ; 10 \%$ ) phenocrysts of plagioclase. ?Feldspar laths in the groundmass extremely fine, felted and moderately well oriented parallel with the main flow bands. $\mathrm{XRF}$ analysis of sample LM 28 from the type area indicates a rhyodacitic composition (Tables $22^{*}, 23^{*}$ ). Kelk (1986) reported breccias belonging to the member at 0290100E 6486500 (Temi 1:25 000 sheet) adjacent to Ardglen.

Relationships Both conformable and disconformable with units in the Woodton Formation in the Back Creek Anticline. Disconformably overlain by either the Lower Permian Temi Formation or Werrie Basalt.

Age Earliest Permian. Asselian.

\section{ISISMURRA FORMATION}

Name After the property Isismurra 0315600E $6474400 \mathrm{~N}$ (Timor 1:25 000 sheet).

Synonymy Isismurra Formation (Manser 1968) south of the Waverley Fault; Isismurra Formation (Roberts \& Oversby 1974; Roberts et al. 1991).

Distribution Crops out in the western and southern parts of the Rouchel block (Roberts et al.1991).

Type locality Section 4 Dangarfield of Roberts and Oversby (1974) is taken as the type section. It contains a minor fault and is incomplete at the top of the formation.

Thickness $620 \mathrm{~m}$ in the type section. Greater than $670 \mathrm{~m}$ in Section 37 Scrumlo (Roberts \& Oversby 1974).

Lithology See Roberts and Oversby (1974) and Roberts et al. (1991).

Age Visean.

\section{Curra Keith Tongue}

Stratigraphic details of the Curra Keith Tongue of the Native Dog Member were given by Roberts and Oversby (1974). The tongue was redated because the original SHRIMP SL13 age (Roberts et al. 1995a) age was complicated by problems of inheritance and $\mathrm{Pb}$ loss. The age of the Curra Keith Tongue is used to calibrate the boundary between the Tournaisian and Visean Stages of the Carboniferous (Roberts et al. 1995a).

Age Sample 542-1 (Figure 13c) has a SHRIMP AS3 age of $349.5 \pm 1.8$. Ma. Visean.

\section{Unnamed red ignimbrites A, B and D of Caldwell (1985)}

Distribution Four discontinuous or fault-bounded bands of red ignimbrite crop out in fault blocks between the Isis and Pages Rivers west and south of Merric (0314820E 6466800N Waverley 1:25 000 sheet) (Caldwell 1985). Ignimbrite $A$ is distinguished from others by its stratigraphic position only $60 \mathrm{~m}$ above the Curra Keith and Oakfields Tongues, coarser lithology and possibly its normal polarity. Ignimbrites D and B are lithologically identical and have the same SHRIMP AS3 age; they are interpreted as the same unit. Ignimbrite D has reversed polarity (Geeve 2000). The fourth ignimbrite may be equivalent to ignimbrite $\mathrm{A}$.

Thickness Ignimbrite A has a thickness of $50 \mathrm{~m}$ and ignimbrite B $15 \mathrm{~m}$ in a section measured west of Merric (Caldwell 1985). Ignimbrite D is $18 \mathrm{~m}$ thick in section 524 (Figure 10).

Lithology Ignimbrite A is bright red and unwelded, and contains phenocrysts $(<0.5-3 \mathrm{~mm}$ : $25 \%)$ of plagioclase, opaque minerals, and fragments of pumice and fine to coarse $(>6 \mathrm{~mm})$ feldspathic volcanic rocks. Shards are poorly oriented, thick and replaced by strongly ferruginised zeolite; triaxons are common and vesicles largely intact. The groundmass is a mosaic of chlorite and zeolite. Ignimbrites B and D contain similar phenocrysts $(<0.5-2.5 \mathrm{~mm} ; 20-25 \%)$, but differ from Ignimbrite A in having less dense phenocrysts, a paler colour, and containing rare quartz and volcanic rock fragments and closely packed shards.

Age Sample 532-1A from Ignimbrite B (Figure 13d) has a SHRIMP AS3 age of $346.3 \pm 2.7 \mathrm{Ma}(\mathrm{MSWD}=0.61)$. Sample 527-24 from Ignimbrite D (Figure 13e) has a SHRIMP FC1/AS3 age of $346.8 \pm 2.1$ Ma. Visean.

\section{RED IGNIMBRITES MAPPED BY SAXTON 1984}

A belt of Isismurra Formation between the Isis River south of Merric and Belltrees contains a major red ignimbrite located stratigraphically below an 
intercalation of the marine Woolooma Formation (Saxton 1984). At Upper Rouchel, however, the Woolooma Formation underlies the first of three red ignimbrites $[a, b$ and $c$ and their lateral equivalents (Roberts \& Oversby 1974)] in the Isismurra Formation. Brachiopods of the Inflatia elegans Subzone of the Delepinea aspinosa Zone indicate that the Woolooma Formation at Upper Rouchel is older than that between the Isis River and Belltrees, which contains a fauna including the trilobite Linguaphillipsia elongata elongata (Mitchell), typical of the younger Linoprotonia tenuirugosa Subzone of the D. aspinosa Zone (Engel \& Morris 1990). Hence, it is possible that the red ignimbrite below the Woolooma Formation in the north is the same as the lowest red ignimbrite (unnamed ignimbrite $a$ and lateral equivalents) of Roberts and Oversby (1974) and ignimbrite A of Caldwell (1985). The reversed polarity of Ignimbrite D (Geeve 2000) may indicate correlation of ignimbrite B/D (Caldwell 1985) with unnamed red ignimbrite $c$ (Roberts \& Oversby 1974) at Upper Rouchel.

\section{SEAHAM FORMATION}

Synonymy Seaham Formation (Sussmilch \& David 1920; Engel 1966; Roberts et al. 1991); Grahamstown Lake Formation (Rattigan 1967).

Distribution Extends from the western margin of the Myall block at Raymond Terrace in a narrow belt along southern parts of the Gresford and Rouchel blocks and then northwards along the western margin of the Rouchel block to the Waverley Fault; it is also present at Mt View near Cessnock (Brakel 1972).

Lithology Details on the succession in the Myall, Gresford, and southern Rouchel blocks are given in Roberts et al. (1991). In the northern part of the Rouchel block, a granitic boulder to cobble conglomerate up to $300 \mathrm{~m}$ thick at the base of the Seaham Formation marks a major disconformity with the underlying Isismurra Formation. The conglomerate is present at Merric (section 527, Figure 9), immediately south of the Waverley Fault, and around the southern margin of Black Mountain; it is normally poorly exposed but readily identifiable by an abundant scree of large granitic clasts. Between the conglomerate and the Elmswood Ignimbrite Member, the section contains coarse to fine, beige, grey or purple volcanolithic sandstone, some cross-bedded, thick beds of grey to beige pebble and cobble conglomerate, both matrix and clast supported, and multicoloured siltstone, some of which is highly silicified. One particular conglomerate differs from others in containing abundant clasts of the Curra Keith Ignimbrite Tongue from the Isismurra Formation (locality 535-3A 0309160E 6460830N Parkville 1:25 000 sheet). In the vicinity of Kewell Creek, at the western margin of Black Mountain, the first $560 \mathrm{~m}$ of the succession above the Elmswood Ignimbrite Member is dominated by interbedded pebble to cobble conglomerate and coarse, zeolitic, volcanolithic sandstone. The remaining $440 \mathrm{~m}$ of the section to the base of the Kewell Creek Volcanic Member has fewer conglomerates but a greater proportion of thinly bedded to laminated siltstone and interbedded volcanolithic sandstone. This pattern does not persist laterally; for example, fewer siltstones are present beneath the Kewell Creek Volcanic Member on Staircase Mountain, possibly because of poor exposures; and farther west, there are fewer conglomerates in the lower part of the sequence. The sedimentary sequence above the Kewell Creek Volcanic Member varies in thickness because of erosion prior to deposition of the Lower Permian Temi Formation. It consists predominantly of interbedded coarse grained, thickly bedded, grey to beige volcanolithic sandstone and pebble conglomerate, with minor grey to beige siltstone. The sandstones have angular, poorly sorted grains and are cemented by zeolite and chlorite. Detrital material in the sandstone and conglomerate consists of quartz, feldspar, mainly Carboniferous dacitic ignimbrites and lavas and andesite lavas, as well as minor quartzite and granite. A thin, unnamed bleached ignimbrite from towards the upper part of the preserved section on the northwestern slope of Black Mountain (locality 544-20 0302470E 6464604N Parkville 1:25 000 sheet) is the only volcanic unit above the Kewell Creek Volcanic Member in the northern part of the Rouchel block. The unnamed ignimbrite has small phenocrysts of plagioclase, slender fibrous pumice fragments and ferruginised rock fragments; shards are thick, mainly flat, and well aligned, and the groundmass is micropoikilitic.

Age Latest Visean or early Namurian to possibly Stephanian.

\section{Elmswood Ignimbrite Member (new name) (S1)}

Derivation of name After the property Elmswood (0311890E 6459350N) Waverley 1:25 000 sheet).

Distribution Extends as narrow, faulted belt from just west of the main southern track from Black Mountain homestead to the crest of Black Mountain (0305000E $6461050 \mathrm{~N})$ to a fault $100 \mathrm{~m}$ west of Lagoon Creek (0309225E 6461878N Parkville 1:25 000 sheet). A second belt on the steep eastern flank of Lagoon Mountain between about $0311700 \mathrm{~N} 6464700 \mathrm{E}$ and $0311100 \mathrm{E} 64627000 \mathrm{~N}$ (Waverley 1:25 000 sheet) appears to represent the upper part of the unit.

Type locality Locality 538-14 0306943E 6460297N (Parkville 1:25 000 sheet) ( $\left.31^{\circ} 58^{\prime} 37^{\prime \prime} \mathrm{S}, 150^{\circ} 57^{\prime} 25^{\prime \prime} \mathrm{E}\right)$ adjacent to the track from Elmswood to the crest of Black Mountain and $0.2 \mathrm{~km}$ east of a major power transmission line crossing the eastern flank of Black Mountain. This locality reflects the upper part of the unit but is unaltered in contrast to exposures to the east of a fault west of Kewell Creek.

Thickness $15 \mathrm{~m}$ in section 530, adjacent to Kewell Creek. Lithology Lower part of flow slightly welded, grey to purple, with phenocrysts (up to 2.5 or $3 \mathrm{~mm} ; 10-20 \%$ ) of plagioclase, embayed quartz, rare biotite and opaque minerals. Pumice fragments elongate, thin, and strongly recrystallised. Shards thick, arcuate to less commonly flat and well aligned; triaxons present. Vesicles large and slightly compressed. Groundmass is a chlorite-zeolite mosaic. Upper part of flow unwelded, beige to brown, finer than lower part, with sparse, small to medium (up to $1.5 \mathrm{~mm}$ : $\sim 10 \%$ ) phenocrysts of 
the same minerals. Shards slender and strongly arcuate or triaxons and vesicles intact and undeformed. Groundmass strongly micropoikilitic. Minor volcanic rock fragments are present in both parts of the flow.

Age Sample 538-40 (Figure 13f) has a SHRIMP AS3 age of $326.4 \pm 2.6 \mathrm{Ma}$. Latest Visean to early Namurian.

\section{Kewell Creek Volcanic Member (S2)}

Derivation of name After Kewell Creek, a tributary of the Pages River in the region adjacent to Black Mountain.

Synonymy Kewell Creek Tuff Member of the Rossmore Formation (Manser 1967, 1968).

Distribution Crops out in a discontinuous belt adjacent to the Hunter Thrust between Springvale in the north and the southern margin of Bells Mountain, and in a continuous, arcuate body extending from $2 \mathrm{~km}$ west of Lagoon Mountain to Staircase and Black Mountains, terminating about $4 \mathrm{~km}$ northeast of Parkville. The most prominent outcrops are between Staircase Mountain and Black Mountain and on Scone, Colonel and Bells Mountains; outcrops in the block southeast of Scone township are generally less well exposed and tentatively assigned to the member on the basis of ash fall ignimbrites and less common ash flow ignimbrites.

Type locality The type section, as redefined in this study, is on Colonel Mountain between 0308354E $6437792 \mathrm{~N}$, east of the crest of the mountain, to $0307083 \mathrm{E}$ 6437744N (Aberdeen 1:25 000 sheet) on the western slope $\left(32^{\circ} 10^{\prime} 48^{\prime \prime} \mathrm{S}, 150^{\circ} 58^{\prime} 02^{\prime \prime} \mathrm{E}\right.$ to $\left.32^{\circ} 10^{\prime} 49^{\prime \prime} \mathrm{S}, 150^{\circ} 57^{\prime} 14^{\prime \prime} \mathrm{E}\right)$. This section is thicker and contains a greater variety of lithologies than those at and adjacent to an unpublished type locality on Kewell Creek (Manser 1967).

Thickness $155 \mathrm{~m}$ in the type section; $\sim 550 \mathrm{~m}$ on Bells Mountain.

Lithology A composite unit consisting of interbedded, dacitic ash-flow and ash-fall ignimbrites, volcanic agglomerate, epiclastic conglomerate, volcanolithic sandstone and multicoloured, ash-rich siltstone. Ashflow ignimbrites are unwelded to moderately welded and have a rhyodacitic to dacitic composition (samples LM1 and LM2, 0308490E 6466370N and 0307820E $6465910 \mathrm{~N}$ : Tables $22 *, 23 *$ ). They range in colour from grey to beige, pink, red, purple or white and normally contain medium to coarse (1.5-2, rarely to $3.5 \mathrm{~mm}$ ) phenocrysts $(10-30 \%)$ of plagioclase, quartz, biotite, and opaque minerals; in some cases, biotite and/or quartz may be absent. Pumice fragments range from abundant to absent. Shards and vesicles are abundant, normally large, thick and axiolitic. The groundmass is micropoikilitic, a chlorite and zeolite mosaic or spherulitic.

Other lithologies include:

(1) A hornblende-bearing ignimbrite present at or near the base of the member at Black Mountain (localities 284-2 and 545-26 0308600E 6461200N and 0305368E 6462085N), Springvale (locality 543-22 0301440E 6464594N, all on the Parkville 1:25 000 sheet) and Colonel and Bells Mountains (localities 555-4 0308354E 6437792N and 559-7A 0309316E 6431535, Aberdeen 1:25 000 sheet, respectively). Two occurrences in a fault block south of Springvale (localities 551-44 0300400E 6463806N and 551-47, Parkville 1:25 000 sheet) cannot be assigned a stratigraphic position because of poor outcrop and faulting. Apart from the presence of hornblende in place of biotite and, in some instances, a greater abundance of phenocrysts $(\sim 35-40 \%)$, the hornblende-bearing ignimbrite is similar in composition to the most common form (above).

(2) Fine, flow-foliated ignimbrite is present at Black Mountain (locality 547-10 0301994E 6462572N), Springvale (locality 543-5 0300111E $6466107 \mathrm{~N}$ ), on the track from Black Mountain to Springvale (locality 545-15 0305725E $6462991 \mathrm{~N}$, both on Parkville 1:25 000 sheet), and on the northern part of Scone Mountain (locality 562-7 03020084E 6456712N Scone 1:25 000 sheet). Phenocrysts are the same as in the predominant type of ignimbrite, but are smaller (1.5-2 $\mathrm{mm}$, rarely $2.5 \mathrm{~mm}$ ) and more scattered $(10-15 \%)$, and there are thin, discontinuous, horizontal lineations of chalcedony. Shards are not visible. The groundmass is micropoikilitic or spherulitic.

(3) Unwelded ignimbrite containing scattered $(\sim 10)$, small $(<0.5-2 \mathrm{~mm}$ ) phenocrysts of quartz and plagioclase and delicate, undeformed shards and vesicles in a mosaic of chlorite and zeolite. These occur at Staircase Mountain (localitiy 536-1, 0308490E 6466374N Parkville 1:25 000 sheet) and on Scone Mountain (locality 563-15, 0302465E $6452218 \mathrm{~N}$, Scone 1:25 000 sheet); a similar ignimbrite is present on Bells Mountain, $160 \mathrm{~m}$ below the main body of the Kewell Creek Volcanic Member (locality 559-5, 0309896E 6432257N Aberdeen 1:25 000 sheet).

Ash-fall ignimbrites are red to white and contain very fine phenocrysts of quartz, broken shards and pumice debris; the original glassy groundmass is largely replaced by pink-stained zeolites; this rock type is present at Scone Mountain (locality 563-5, 0301450E $6451525 \mathrm{~N}$ ) and on the eastern part of St Aubins (locality $566-7 \mathrm{~A}$ at and adjacent to $0301066 \mathrm{E} 6445897 \mathrm{~N}$, both localities on Scone 1:25 000 sheet). XRF analyses (samples LM1 and LM3: Tables $22^{*}, 23^{*}$ ) indicate a rhyodacitic to dacitic composition.

Depositional environment The significant content of epiclastic sediments in the member, together with a predominance of ash-flow over ash-fall ignimbrites, indicates deposition on the proximal to medial flanks of a volcanic centre.

Geomorphic expression Mountains and ridges containing cliff lines.

Age. Sample 284-2 (Figure 14a), from the base of the member, has a SHRIMP AS3 age of $320.5 \pm 2.8 \mathrm{Ma}$. Namurian.

\section{Well Gully Ignimbrite Member (new name) (S3)}

Derivation of name After Well Gully, a tributary of Sandy Creek on the Aberdeen 1:25 000 sheet).

Distribution and type locality Known only from a single outcrop $2 \mathrm{~km}$ northeast of Well Gully homestead (0304480E 6497120N Aberdeen 1:25 000 sheet) (31 $38^{\prime} 40^{\prime \prime} \mathrm{S}$, $\left.150^{\circ} 56^{\prime} 17^{\prime \prime} \mathrm{E}\right)$, west of Colonel Mountain.

Thickness $10-15 \mathrm{~m}$.

Lithology Grey to beige, unwelded ignimbrite containing medium to coarse $(1-1.5 \mathrm{~mm}$, rarely to $3.5 \mathrm{~mm})$ phenocrysts $(\sim 10 \%)$ of quartz, altered feldspar and irregular, recrystallised pumice fragments. Shards unoriented, slender, small, frequently triaxons, 
accompanied by broken and intact vesicles. Groundmass micropoikilitic.

Age Sample 556-5 (Figure 14b) has a SHRIMP AS3 age of $305.7 \pm 2.7 \mathrm{Ma}$. Latest Westphalian to earliest Stephanian.

\section{APPENDIX 2: SHRIMP DATING PROCEDURES}

Heavy-mineral concentrates were prepared from totalrock samples using standard crushing, desliming, heavy-liquid (SG 2.96 and 3.3), and paramagnetic procedures. Zircons were hand-picked from the mineral separates, mounted in epoxy together with chips of the AS3 (or FC1) reference zircons, sectioned approximately in half and polished. Reflected- and transmitted-light photomicrographs were prepared for all zircons. Cathodoluminescence SEM images have been used to decipher the internal structures of the sectioned grains and to select for analysis-specific simple magmatic zones within the grains.

The $\mathrm{U}-\mathrm{Th}-\mathrm{Pb}$ analyses were made using SHRIMP II and, in some cases, SHRIMP I at the Research School of Earth Sciences, Australian National University, Canberra. Each analysis consisted of six scans through the mass range, with a reference zircon analysed for every three unknown zircon analyses. The data have been reduced in a manner similar to that described by Williams (1998 and references therein), using the SQUID Excel Macro of Ludwig (2000). The $\mathrm{Pb} / \mathrm{U}$ ratios have been normalised relative to a value of 0.01859 for the AS3 Duluth Gabbro reference zircon, equivalent to an age of $1099 \mathrm{Ma}$ (Paces \& Miller 1993). Uncertainties given for individual analyses (ratios and ages) are at the $1 \sigma$ level, although the uncertainties in calculated weighted mean ages are reported as 95\% confidence limits. The Tera and Wasserburg (1972) concordia plots, probability density plots with stacked histogram, and weighted mean ${ }^{206} \mathrm{~Pb} /{ }^{238} \mathrm{U}$ age calculations were carried out using ISOPLOT/EX (Ludwig 1999), and are reported in Tables $2^{*}-21^{*}$ and shown in Figures 11-14. Comments on the SHRIMP dates are given in Appendix $3^{*}$.

The 20 samples reported herein were analysed relative to the AS3 reference zircon over 12 extended sessions, together with a number of other samples in this study reported elsewhere. For samples 465-13A,

\section{SUPPLEMENTARY PAPERS}

Appendix 3 Comments on SHRIMP dates.

Table 2 Summary of SHRIMP U-Pb zircon results for sample 284-2.

Table 3 Summary of SHRIMP U-Pb zircon results for sample 287-2A.

Table 4 Summary of SHRIMP U-Pb zircon results for sample 465-13A.

Table 5 Summary of SHRIMP U-Pb zircon results for sample 466-15.

Table 6 Summary of SHRIMP U-Pb zircon results for sample 469-43.

Table 7 Summary of SHRIMP U-Pb zircon results for sample 470-13.

Table 8 Summary of SHRIMP U-Pb zircon results for sample 472-1.
Correlatives A thin, bleached, unnamed ignimbrite from above the Kewell Creek Volcanic Member on the northwestern slope of Black Mountain (locality 544-20, 0302470E 6464604N Parkville 1:25 000 sheet) occupies a comparable stratigraphic position.

466-15, 469-43, 470-13 and 472-1, an extended SHRIMP I session was run in addition to a SHRIMP II session. The uncertainties in the $\mathrm{U} / \mathrm{Pb}$ calibration of AS3 were $0.54 \%$ and $0.57 \%$, respectively, for these two sessions. All other analyses were analysed using SHRIMP II, and the data are reported relative to the AS3 reference zircon $\mathrm{U}-\mathrm{Pb}$ calibrations; the uncertainties in the $\mathrm{U} / \mathrm{Pb}$ ratio calibrations being $0.33 \%, 0.46 \%, 0.27 \%$, $0.39 \%, 0.63 \%, 0.52 \%, 0.53 \%, 0.27 \%$ and $0.51 \%$, respectively, as given in the footnotes for each sample data tabulation.

The analyses of samples 527-24 and 542-1 were made in an extended SHRIMP II session together with a number of other samples from a related study. During this session, both the AS3 and FC1 reference zircons were analysed; the uncertainty in the $\mathrm{U} / \mathrm{Pb}$ calibration relative to AS3 was $0.27 \%$ for 20 of 23 analyses and $0.31 \%$ for 20 of 22 analyses of $\mathrm{FC} 1$. Weighted mean ${ }^{206} \mathrm{~Pb} /{ }^{238} \mathrm{U}$ ages calculated for these samples relative to AS3 and FC1 differ by $<0.1 \%$; for $527-24$, the weighted mean ages are 347.1 Ma versus $346.8 \mathrm{Ma}$, and for 542-1, they are 349.5 Ma versus 349.6 Ma, respectively for AS3 and FC1 calibrations. This is well within the long-term external analytical SHRIMP $\mathrm{U}-\mathrm{Pb}$ uncertainty of $\pm \sim 1 \%$ at $95 \%$ confidence limits [as determined by M. Fanning \& R. Armstrong (unpubl. data) and many others, e.g. Stern \& Amelin (2003)]. Therefore, at the $\pm 1 \%$ level, $\mathrm{U}-\mathrm{Pb}$ ages relative to AS3 and $\mathrm{FC} 1$ are indistinguishable. Further, during the extended SHRIMP II session during which sample 556-5 was analysed, 17 of 18 analyses of the Temora reference zircon (Black et al. 2003b) gave a weighted mean ${ }^{206} \mathrm{~Pb} /{ }^{238} \mathrm{U}$ age of $417 \pm 4$ Ma $(\mathrm{MSWD}=3.2$ ). This demonstrates that, at least for that analytical session, there is no bias between the $\mathrm{U}-\mathrm{Pb}$ calibration of the AS3 (or FC1) Duluth Gabbro reference zircon and Temora.

Table 9 Summary of SHRIMP U-Pb zircon results for sample 488-2A.

Table 10 Summary of SHRIMP U-Pb zircon results for sample 488-16C.

Table 11 Summary of SHRIMP U-Pb zircon results for sample 490-2.

Table 12 Summary of SHRIMP U - Pb zircon results for sample 490-2.

Table 13 Summary of SHRIMP U-Pb zircon results for sample 493-9.

Table 14 Summary of SHRIMP U-Pb zircon results for sample 503-1.

Table 15 Summary of SHRIMP U-Pb zircon results for sample 501-4. 
Table 16 Summary of SHRIMP U-Pb zircon results for sample 505-1.

Table 17 Summary of SHRIMP U - Pb zircon results for sample 527-24.

Table 18 Summary of SHRIMP $\mathrm{U}-\mathrm{Pb}$ zircon results for sample 532-1A.

Table 19 Summary of SHRIMP U-Pb zircon results for sample 538-40.
Table 20 Summary of SHRIMP U-Pb zircon results for sample 542-1.

Table 21 Summary of SHRIMP U-Pb zircon results for sample 556-5.

Table 22 XRF analyses.

Table 23 XRF sample localities. 